Historic, Archive Document

Do not assume content reflects current scientific knowledge, policies, or practices. 

62,61

CW.STIART \& $C^{\circ}$

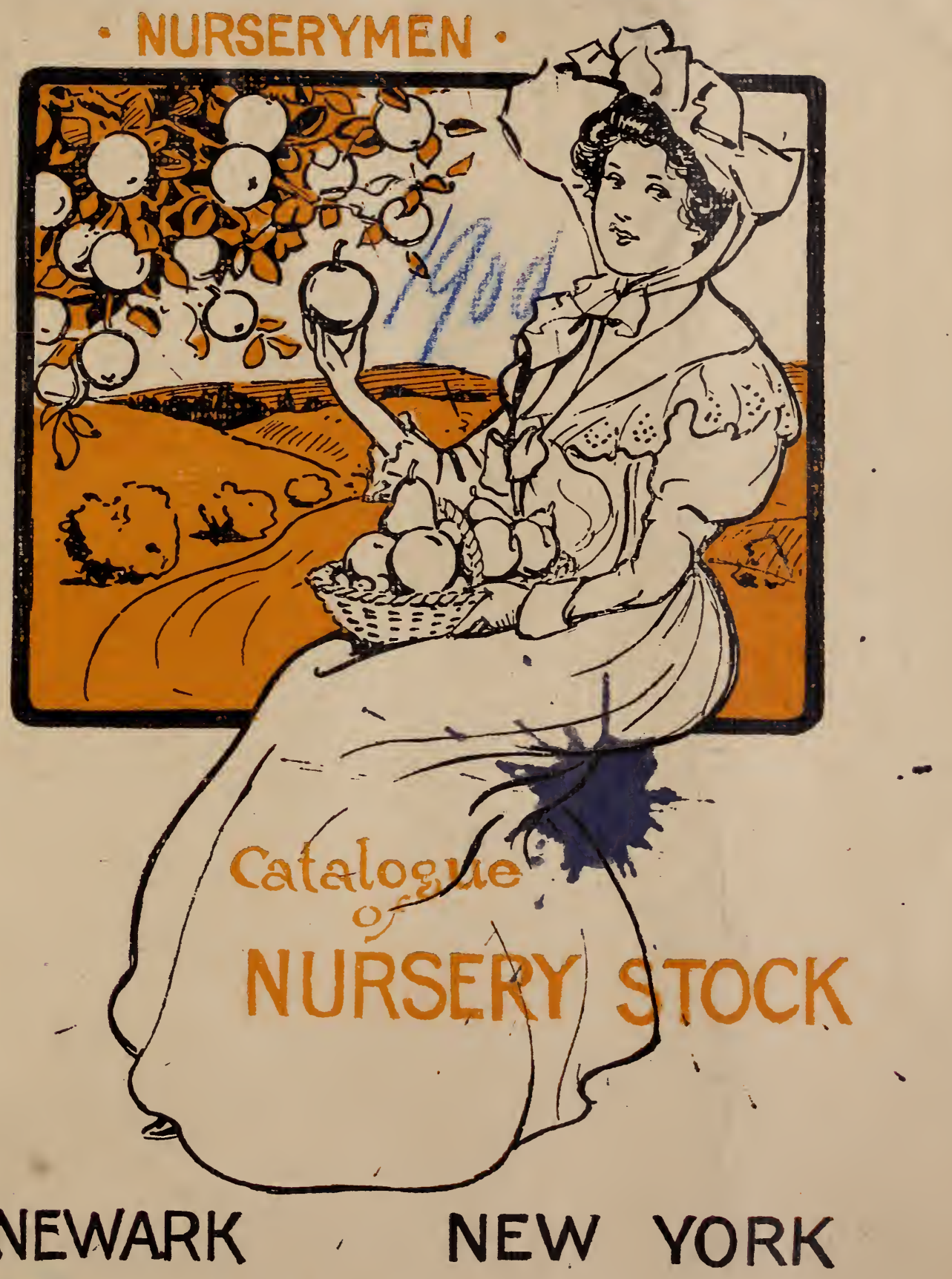




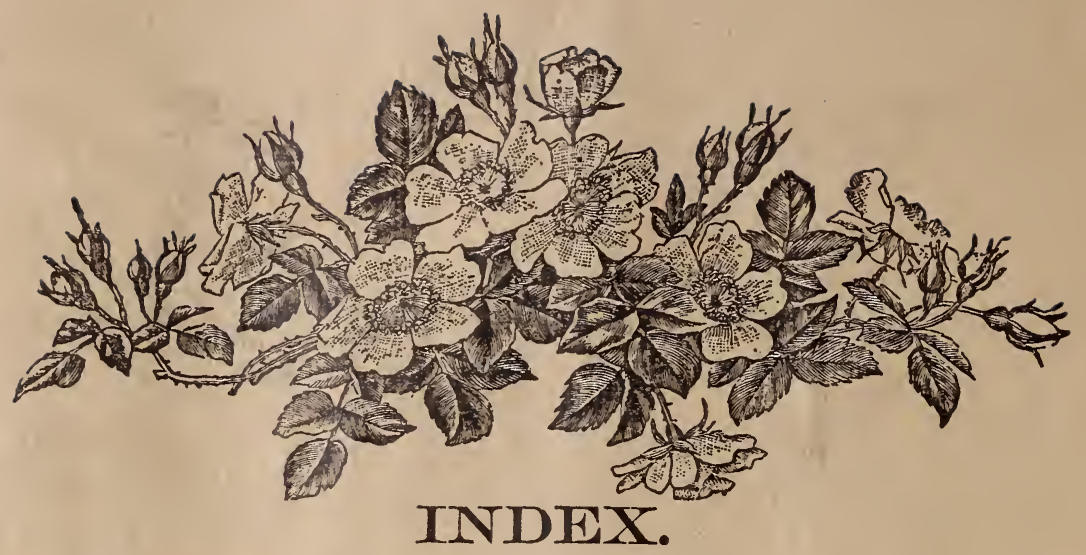

\section{Fruit Department.}

Apples $\ldots \ldots \ldots \ldots$ PAGE

Apricots ..........26

Asparagus .........30

Blackberries .......34

Cherries ........15, 16

Crab Apples ........99

Currants ..........31

Dewberry ..........34

Gooseberries .......35

Grapes .........28, 30

Nectarines .........25

Peaches ........22, 25

Pears ...........10, 14

Plums ..........17, 21

Quinces ...........27

Raspberries .....32, 33

Rhubarb ..........31

\section{Ornamental Trees.}

Acer ..............38

Aesculus ..........36

Ash ..........38, 39

Basswood ...........36

Beech ............36

Betula ..........36

Birch ............36

Box Elder .........36

Butternut ........36

Castanea ........36, 37

Catalpa ..........36

Chestnut ........36, 37

Chionanthus .......37

Elm ..............37

Fagus ...............36

Fringe ............37

Horse Chestnut ....37

Juglans ..........40

Linden ...........38

Liriodendron ......40

Magnolia ............38

Maple .............38

Mountain Ash....38, 39

Mulberry ..........39

Poplar ...........39

Populus ..........39

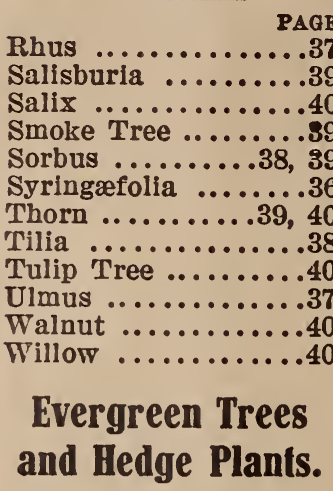

Abies .............41

Arborvitae ........41

Honey Locust .......42

Juniper ...........41

Ligustrum ........42

Pine .............41

Privet California ....42

Spruce ........41, 42

\section{Ornamental Shrubs.}

Althr, or Rose of

Sharon ..........43

Azaleas ..............43

Barberry ..........43

Barberis ............43

Calycanthus, or Sweet

Scented Shrub.....43

Cornus ............44

Cydonia ............45

Deutzia ..........44

Dogwood .............44

Fringe $. . . \ldots \ldots \ldots . . .44$

Hibiscus ..........43

Honeysuckle ........44

Hydrangea ........44

Lilac ............45

Lonicera ...........44

Maple, Japan ......45

Mock Orange .......45
Pronia PAG

Philadelphus .........46

Quince, Japan .....45

Rhododendron ......45

Rose of Sharon......45

Snowball .........46

Spiræa ............46

Strawberry Tree ....47

Syringea .......46, 47

Tree Pronies ......47

Viburnum ..........47

Weigela ..........47

\section{Vines and Creepers.}

Ampeolopsis .......48

Clematis .......48, 49

Hedera ............50

Honeysuckle .....49, 50

Ivy $\ldots \ldots \ldots \ldots . .50$

Japan, or Boston Iry..50

Wisteria ..........50

\section{Bulbs and Herba- ceous Plants.}

Anemone ...........51

Cannas .............51

Cone Flower .......51

Gladiolus ..........51

Hollyhocks .......51

Iris $\ldots \ldots \ldots \ldots .50,51$

Lillies .............52

Pæonies, Herbaceous.52

Rudbeckia .........52

Windflower ........51

Roses.......53 to 60

INSECTS AND DISEASES, WITH REMEDIES.... ..........61, 62,63

Distances for Plant

ING ..........63

Number Plants Re-

QUIBED FOB AN

ACRE ...........63

Spraying Calendar..64 


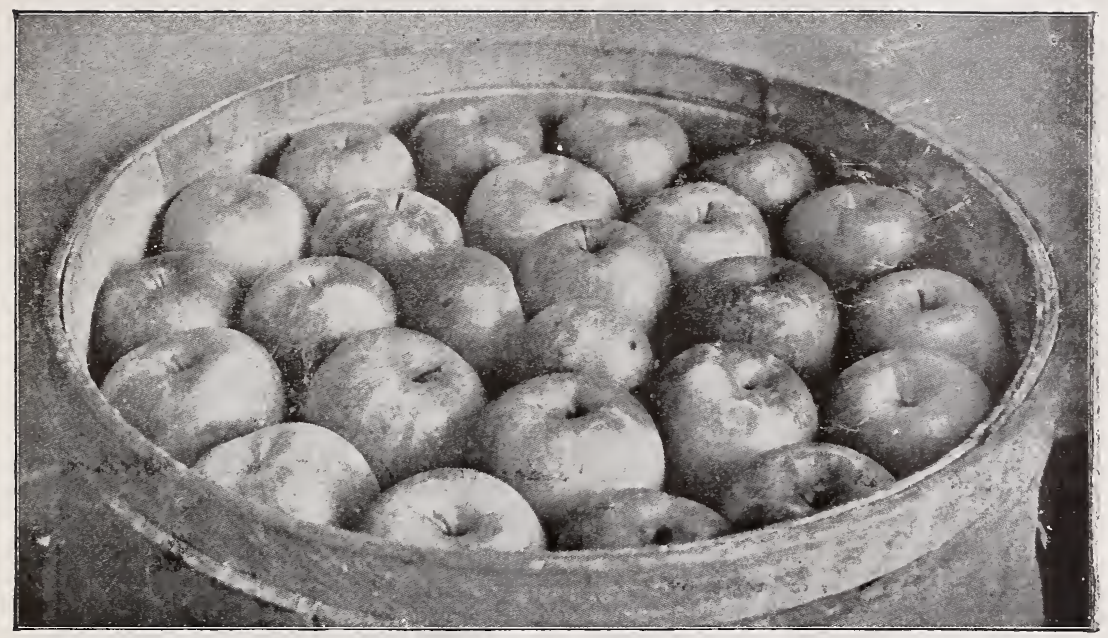

FROM COUNTRY LIFE IN AMERICA. COPYRIGHT 1901 BY DOUBLEDAY, PAGE \& CO.

\section{SELECT APPLES.}

THE varieties described below are the best known in cultivation, their value having been well proved by thorough tests. The list comprises our principal stock of Apples. Our nurseries. are in the very best tree-growing section to be found, where the good constitution and great. hardiness of wood in the young tree is attained by a much slower growth than the rushing overgrowth of some portions of our country.

In our Price List we present a list specially selected for the extreme hardiness of the tree: and the excellence of the fruit-varieties that can be depended upon to produce fruit of fine: quality, in abundance, in the cold sections.

RIPENING-The season of the year when the fruit is fully ripe and at its best to use is indicated by the letter $S$ for summer season, $A$ for autumn season, $W$ for winter season, together with the particular months of that season. This is the time of maturity in the westerc part of New York State; will vary north and south

Alexander. $A$-October to December. Extra hardy. Sour. Red, striped. Fruit large, streaked with bright red on greenish yellow. Flesh yellowish white, rather crisp, subacid. A coarse sort, suitable for cooking. A moderate bearer only. This is a very handsome Russian Apple, and like all others from that country, valuable on account of its hardiness, being suited to the extreme north.

America. $W$-December to February. Extra hardy. Sour. Red, striped. Good size. Color deep red. The originator says it keeps perfectly with him until February or March. Perfectly hardy in western New York. An excellent keeper. Its handsome, showy appearance and keeping qualities, entitle America to rank high.
Arkansas. W-January to April. Sour. Red, striped. Fruit medium size, slightly conical, regular, smooth. Color glossy yellow, generally covered with deep crimson. Flesh yellowish, fine grained, firm, juicy, subacid. Quality rich, very good. Tree a good bearer. A commanding market Apple. Origin, Arkansas.

Autumn Strawberry. $A$-October to December. Sour. Red, striped. Fruit medium size, roundish or inclined to an oval shape. Nearly whole surface of skin has small, broken streaks of light and dark red. Flesh yellowish white, slightly fibrous, tender, juicy, subacid, and very pleasant and agreeable flavor. Bears yourg, and is loaded with crops of fine fruit. Succeeds well in the west. Ripens in early au tumn and keeps until winter. 
Baily's Sweet. $W-$ November to April. Sweet. Red, striped. Fruit large, the whole surface frequently a full, bright red, in small, broken, indistinct stripes and dots, on light ground. Flesh very tender, not juicy; flavor mild, rich, sweet, fine. Tree a vigorous, upright grower and a good bearer. Origin, Wyoming county, N. Y.

Baldwin. W-November to March. Sour. Red, striped. Fruit rather large, shaded and striped with yellowish red and crimson on yellow ground. Flesh yellowish white, with a rich subacid flavor. Tree very vigorous and productive. Very popular in most of the northern states, and more extensively grown than any other variety.

Baxter. $W$-November to March. Extra hardy. jour. Red, not striped. Fruit above medium size. Color dark red, spotted. Mild subacid; quality good. Originated in Canada, on the banks of the St. Lawrence.

Belle de Boskoop. W-February to April. Extra hardy. Sour. Red, striped. Mr. Downing says: "A new variety, said to be of Russian origin. Tree vigorous, spreading; comes into bcaring moderately young, and produces abundantly ir alternate years. Fruit medium to large, roundish oblate. Skin yellow, shaded with light and dark red over nearly the whole surface, some specimens more or less mixed with russet. Flesh a little coarse, crisp, tender, brisk subacid, of very good quality. Core small and close."

Bellflower. $W$-December to February Sour. Yellow, not striped. Fruit large. Skin yellow, with a tinge of red on the sunny side Flesh tender, juicy, crisp, with a sprightly sub. acid flavor, and when not fully ripe quite acid. An excellent winter Apple, and is highly esteemed as a market fruit. Tree hardy and a vigorous grower, succeeding well on light, sandy soils.

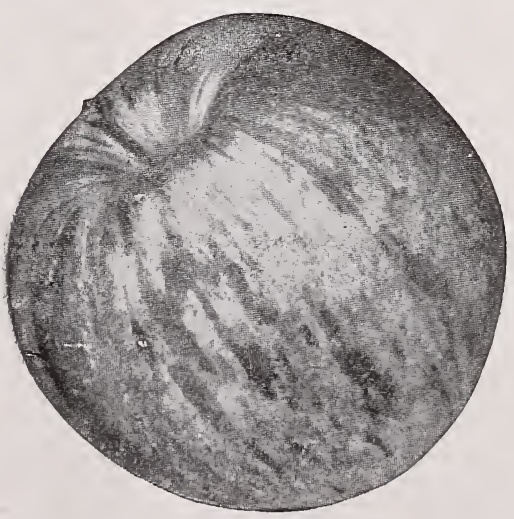

Ben Davis.

Ben Davis (New York Pippin). W-De. cember to March. Sour. Red, striped. Fruit large, roundish, sometimes conical, smooth. Skin striped red on yellow. Flesh white, tender, juicy, with a mild, good but not rich subacid flavor. A very popular Apple in parts of the west and southwest, and is much planted for market, as it commands a high price, and is profitable because of its young bearing qualities. Keeps till midwinter or later.

Bismarck. W-October to January. Red, striped. Fruit good size, good quality. Tree begins to bear when quite young, and is a prolific bearer. Excellent for cooking. Origin, New Zealand.

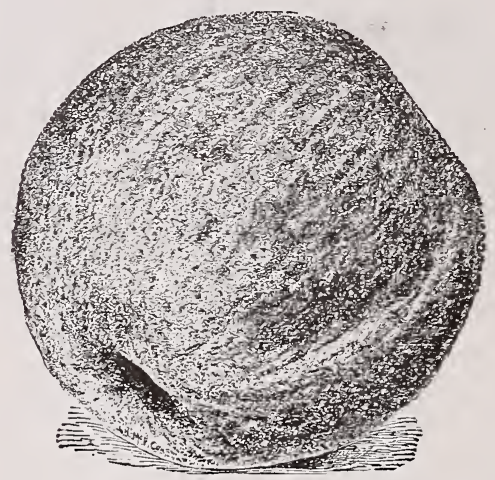

Boiken.

Boiken. $W$-Keeps well till May. Sour. Red, not striped. One of the hardiest and healthiest varieties of Apple grown. It developed fine, large, well-developed specimens of fruit on trees in the nursery row one year from bud. Fruit medium size, roundish. Color bright yellow, with rosy red cheeks, resembling Maiden's Blush. Flesh white. It is said to be scab proof, requiring no spraying to produce fine fruit, and the foliage is said to be so healthy as to withstand the attacks of fungi. The trees have not been attacked with fungus in the nursery row, and have needed no spraying. Origin, Russia.

Bottle Greening. W-December to April: Sour. Green, not striped. Resembles Rhode Island Greening, but tree a better grower, much hardier, and a later keeper. Remark able for its long keeping qualities. We have had good fruit as late as April 20. Native of Vermont.

Canada Red. W-November to May. Sour. Red, striped. Medium size. Skin red, with white dots. Flesh rich, subacid. Tree a moderate, slender grower. Is named Steel's Red by some.

Chenango Strawberry. A-See Sherwood's Favorite. 
Duchess of Oldenburg. A-September. Extra hardy. Sour. Red, Striped. Fruit large, roundish, a little flattened at ends. Skin streaked with red and yellow. Flesh yellowish white, juicy, subacid. Ripens early in the fall. Fruit fair and handsome. Tree a vigorous grower, having fine, large foliage; bears abundantly, and when very young. Succeeds in nearly all sections of the country, and is as valuable in the extreme north as in the south. Of Russian origin, and as hardy as any known variety.

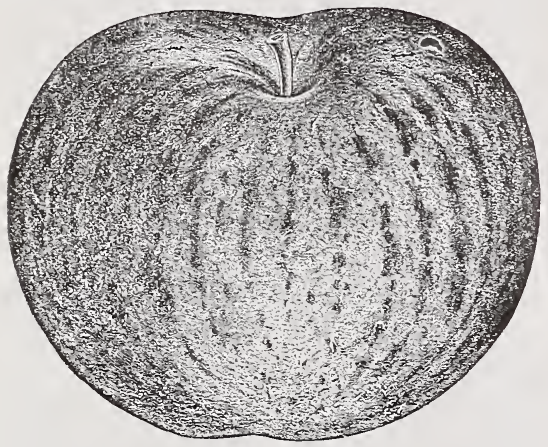

Duchess of Oldenburg.

Early Harvest. $S-$ July and August. Sour. Yellow, not striped. Fruit medium size, roundish. Skin very smooth, with a few faint dots, bright straw color when fully ripe. Flesh very white, tender and juicy, crisp, rather acid flavor. Quality very good. Core small. Popular on account of its beauty and excellent qualities for the table and cooking. Productive; long season. Needs rich cultivation to be fine. Good through the Northern states. Is named Sour Bough by some.

Early Joe. $S$-Middle to last of August. Sour. Red and yellow, striped. Fruit medium size or rather small, approaching conical, smooth and regular. Skin has red stripes on a yellow ground, and a nearly uniform deep red to the sun, with conspicuous white stripes. Flesh fine grained, very tender, slightly crisp, juicy, subacid. Growth slow. A profuse bearer. Origin, East Bloomfield, N. Y.

Early Strawberry. S-Middle to end of August. Sour. Red, striped. Fruit medium size, mostly covered with deep red. Flesh white, slightly tinged with red next the skin, tender, subacid, and very sprightly and brisk in flavor. Tree a moderate, erect grower, and a good bearer.

English Russet. $W$ - January to June. Sour. Greenish yellow, not striped. Fruit medium or rather small, roundish conical, regular. Surface more or less overspread with brownish russet on light, greenish yellow ground; in large, exposed specimens, wholly russetted. Flesh greenish or yellowish white; texture fine, with an aromatic, subacid flavor; a late keeper.
Fallawater. $W$-November to January. Sour. Green, not striped, Fruit rather large, globular. Color yellowish green, dull red cheek, with a few large, whitish dots. Flesh juicy, white, rather fine-grained, crisp, pleasant, subacid flavor. Tree a strong grower, very productive, even while young. Also known as Tulpahocken.

Fall Pippin. A-October to December. Sour. Greenish yellow, not striped. Fruit large, roundish oblong. Skin greenish, becoming a high, rich yellow when ripe. Flesh yellowish, rather firm, becoming tender, and with a rich aromatic flavor. Tree a good grower and moderate bearer. Excellent for cooking. A fine fruit, and succeeds in nearly all sections.

Fameuse or Snow. A-October to January. Sour. Red, striped. Fuit medium size, roundish, somewhat flattened; even. Color, whitish ground, handsomely striped and blotched with fine, deep red, and where much exposed to sun, a deep, nearly uniform red. A very celebrated Canadian fruit, remarkable for the snow-white color of its flesh. Is very tender, crisp and juicy, a little spicy, with a slight perfume. Much admired as a table fruit for its handsome appearance and pleasant, refreshing flavor. Brings a good price in market as a dessert Apple. Tree a good grower, hardy, and a regular bearer of handsome fruit. Valuable in Canada and the northern states. Is named Snow apple by some.

Ganow-February to May. Sour. Red, not striped. Fruit of conical form, good size and smooth. Color deep red, shaded on sunny side to mahogany; very attractive. Flesh pale yellow, fine-grained, tender, pleasant, mild, subacid. A good shipper and keeper. Tree healthy, vigorous and hardy. Annual and prolific bearer. Origin, Missouri.

Gideon. $W$-October to December. Extra hardy. Sour. Yellow, not striped. Raised from seed of a seedling crab by that veteran fruit grower, Peter M. Gideon, of Excelsior, Minn., and to use his language, "is as hardy as a native oak." The fruit is of a rich, golden yellow, with a very clear skin and a handsome rosy blush. Flesh juicy and fine, with an excellent subacid flavor. While its crab origin seems to be thoroughly developed in the hardy, rugged character of the tree, there is no trace of this in the fruit, which is in every respect a fine eating Apple. Originated in Minnesota.

Gilliflower. W-January to April. Sour. Red, striped. Fruit rather large, oblong-ovate or long-conical. Surface dark, dull, reddish purple, inclining to greenish yellow where densely shaded. Flesh greenish white, with a rich, good, slightly subacid flavor. Flesh becomes dry when fully ripe. Keeps through winter and late into spring. A good baking Apple.

Gladstone. A-September. Hardy. Sour. Red, striped. A very handsome Apple, resembling the Duchess of Oldenburg. Good quali- 
ty. Tree is a very strong grower, very hardy, and especially adapted to northern sections, where hardy varieties are required. Fruit large. ' Skin smooth, washed and streaked with red on a yellow ground. Flesh juicy, sprightly, subacid; good.

Golden Russett. $W$-November to April. Sour. Yellow, not striped. Medium size, roundish, usually a little oblong, sometimes slightly flattened. Surface sometimes wholly a thick russet, and at others a thin, broken russet on a greenish yellow skin. Flesh whitish yellow, fine-grained, rather compact, sprightly, mild subacid; good to very good. A thrifty grower and excellent bearer. A most hardy and valuable variety. Succeeds in most all sections, and especially in rich western soils.

Gravenstein. A-September and October. Sour. Greenish yellow, striped. Fruit large, roundish. Skin a little waxy, striped and splashed with bright red on yellow ground. Flesh tender, juicy and crisp, with a slight aromatic flavor, and of first quality. Tree vigorous and productive, bearing regular crops of finely shaped, handsome fruit. Fine in all localities. German origin.

Greening. $W$-See Rhode Island Greening.

Grimes' Golden. $W$-December to Feb. ruary. Extra hardy. Sour. Yellow, not striped. Fruit is above medium size, round or slightly oblong. Skin rich golden yellow, sprinkled with large russet dots. Flesh yellowish white, crisp, tender, rich and juicy, with a mild subacid flavor. Tree hardy, vigorous and productive. It succeeds over a large extent of country, and endures severe cold without injury.

Kubbardston Nonesuch. W-November and December. Sour. Red-yellow, striped. Fruit large. Color, small broken stripes and numerous dots of light, rich red on a rich yellow ground. Flesh yellowish, very rich, slightly subacid, with a strong mixture of a rich, sweet flavor; the finest quality and very valuable. A famous New England sort-fine at the North and Northwest. A native of Massachusetts.

Jonathan. $W$-November until March. Sour. Red, striped. A beautiful dessert Apple. Fruit of medium size, regularly formed, roundish and slightly conical. Skin clear and smooth, the ground color being clear, light yellow, nearly covered by lively red stripes, deepening into brilliant or dark red in the sun. Flesh white, sometimes a little pinkish, very tender and juicy, with a mild, sprightly flavor. Hardy, productive, moderately vigorous. Fruit is one of the best in quality, and profitable for table or for market. Originated, Kingston, New York.

King (King of Tompkins County). $W$ November to March. Sour, Red, striped. Fruit large to very large, roundish. Color a deep red in stripes, making a handsome appearance. Flesh tender, juicy, rich, highly flavored. Commands a high price in market. Tree a strong grower; bears abundantly. Inclined to drop its fruit rather early, and should be gathered soon. Succeeds east and west, at the north, but not so well in the far south.

Langford's Seedling. $W$-January to March. Sour. Yellow, striped. Fruit medium size to large. Color yellow, striped, and nearly covered with bright red. Flesh firm, juicy, mild subacid. One of the best of the late keepers. Origin, Maryland.

Longfield. $W$-December to March. Extra hardy. Sour. Yellow and pink, not striped. A free, upright grower, a young and abundant bearer. Fruit medium size, round. Color yellow, flushed pink, a decided blush on the sunny side. Flesh white, rich, sprightly subacid. Quality good. Russian origin.

Magog Red Streak. W-December to March. Extra hardy. Sour, Red, striped. Tree very thrifty and vigorous, of extreme hardiness, and of great productiveness. Fruit medium size, roundish. Skin light yellow, shaded and faintly striped and splashed with light red over half the fruit. Flesh yellowish, moderately juicy, mild subacid. A very long keeper. Origin, Vermont.

Maiden's Blush. A-August to October. Sour. Yellow, not striped. Fruit rather large, oblate, smooth and regular, with a fine, evenly shaded, red cheek or blush on a clear, pale yellow ground. Flesh white, fine grained, tender, pleasant subacid, but not rich. Tree spreading. Although deficient in richness, it is valued for its fair, tender, beautiful fruit and uniform productiveness. Valuable in the west.

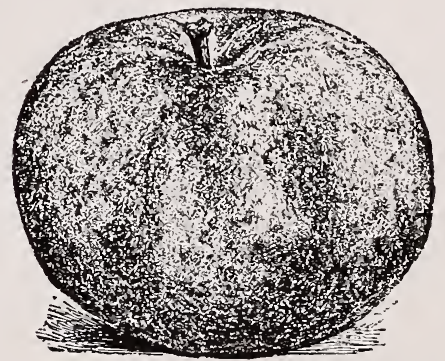

Mann.

Mann. W-January to April, Extra hardy. Sour. Greenish yellow, not striped. Fruit medium to large, nearly round. Skin deep yellow when ripe, with brownish red where exposed. Flesh tender and juicy, with mild, pleasant, subacid flavor. Tree hardy, a good grower, and a young and regular bearer. Keeps well. Popular in the colder localities. Originated in Northern New York.

McIntosh Red. $W$-November to February. Extra hardy. Sour Red, not striped. An exceedingly valuable, hardy Canada sort. Fruit medium size, roundish, nearlv covered with rich 
ed on light yellow skin. Flesh white, fine, very tender, juicy, and refreshing, with a peculiar, quince-like flavor. A good bearer of fair, handsome fruit. Resembles the Fameuse, but larger and more hardy, and fully equal in quality.

Munson's Sweet. $A$-October and November. Sweet. Yellow, not striped. Fruit medium size to large, smooth and regular. Skin pale yellow, with brown blush. Tree a vigorous grower and uniform bearer. A valuable sweet Apple. Flesh yellowish white, tender, with a very good, sweet flavor.

Newtown Pippin. W-December to May, Sour. Yellowish Green, not striped. Fruit medium size or rather large, roundish, oblique. Skin dull green, often with a dull brownish blush. Flesh greenish white, juicy, crisp, fine-grained, with a high, fine flavor. Keeps through spring, and retains its freshness remarkably. Tree of rather slow growth, with a rough bark; slim and small when delivered. The fruit is very liable to black spots or scabs, unless under high, rich and constant cultivation. One of the best fruits for foreign markets. Rarely succeeds well in New England. Tender far west. A native of Long Island, N. Y.

Northern Spy. $W$-January to June. Sour. Red, striped. Fruit large, roundish, somewhat conical in shape. Skin handsomely striped and covered with crimsom on the sunny side, overspread with a thin bloom. Flesh juicy, flavor rich, aromatic, mild subacid, fine. Keeps through winter and late into spring; preserves its flavor remarkably fresh. A tardy bearer. To afford fine fruit, the tree must be kept thrifty by good cultivation. A fruit of highest quality, profitable for market under proper cultivation, with care in picking, assorting and packing. Succeeds in the north and northwest; less valuable farther south. A native of East Bloomfield, N. Y.

Northwestern Greening. $W$-January to Spring. Extra hardy. Sour. Greenish yellow, not striped. This Wisconsin seedling Apple, which received the first prize of the Wisconsin State Horticultural Society over a large competion as a seedling App!e, has been thoroughly tested in most trying places in Wisconsin, and proves to be equal to the Wealthy in every respect as a tree, and has the added merit of being a late keeper. Fruit medium to large, round ovate to conical, smooth. Skin greenish yellow. Flesh fine-grained, firm, juicy, subacid, good. Valuable for the north. Origin, Wisconsin.

Ontario. $W$-January to April. Sour. Red, striped. A hybrid, resulting from a crossing of the Northern Spy and Wagener. Fruit tender and juicy, of mild subacid flavor; bears young, annual crops of good uniform size. Keeps until April. Undoubtedly one of the most desirable hardy varieties yet intro- duced, and in the future is bound to commana a high price in the British market. Bears young, like the Wagner. Origin, Ontario, Canada.

Paradise Winter Sweet. W-November to April. Sweet. Green, not striped. Fruit rather large, regularly formed, roundish. Color pale greenish yellow, with a brown blush. Flesh white, fine grained, juicy, sweet, sprightly, and very good. Succeeds well at the west. Origin, Pennsylrania.

Perry Russet. W-November to December. Sour. Yellow, not striped. Fruit medium size, rounded. Color pale yellow, netted with russet on the sunny side, and sometimes brownish. Flesh yellow, firm, juicy, subacid. Tree a moderate spreading, upright grower, hardy, and a young and abundant bearer. Origin, Perry, N. Y

Pawaukee. W-December to March. Ex. tra hardy. Sour. Red, striped. Fruit medium to large, round. Color, striped with red, on a bright yellow skin. Flesh yellowish white, juicy, subacid; in quality something like Johathan. Tree a strong grower, and very hardy; adapted to the extreme north, and equally as valuable for southern culture. A seedling from the Duchess of Oldenburg.

Pound Sweet. A-October to December. Sweet. Greenish, not striped. Fruit very large, round. Skin pale green. Excellent for baking and culinary purposes. Flesh white, sweet, tender, not juicy. Moderate quality. Tree a free grower and productive. Also called Pumpkin Sweet.

Pumpkin Sweet. $A$-See Pound Sweet.

Quebec Winter Sweet. $W$-December to March. Extra hardy. Sweet. Yellow, not striped. About the size of the Tallman Sweet. Color yellow, with red cheeks. Splendid quality, and very hardy. Originated in the province of Quebec, Canada.

Rawle's Janet. W-January to April. Sour. Yellow, striped. Fruit medium size, roundish, oblong. Color pale red, distinct stripes, on light yellow ground. Flesh nearly white, fine, mild, subacid; fine texture, crisp, juicy. Growth slow. A profuse bearer, with a portion of the crop knotty or under size. Keeps through spring. Highly esteemed in the Ohio valley; does not succeed farther north. The blossoms open ten days later than usual, thus sometimes escaping spring frosts. Hardy far west. One of the most popular Apples in the south and southwest.

Rambo. A-October to December. Sour. Yellow, striped. Fruit medium size, round, flat and smooth. Skin streaked and marbled with dull, yellowish red on pale yellowish ground. Flesh greenish white, very tender, rich, mild subacid. Of very good quality. Fine in nearly all localities. 
Red Astrachan. $S$-Last of July to middle of August. Sour. Red, not striped. Fruit large, roundish. Skin nearly covered with crimson, and with an exquisite, bloom on the surface of the fruit, like that of the plum; an Apple of extraordinary beauty. Flesh quite white, crisp, moderately juicy, with an agreeable, rich, rather acid flavor, and first-rate quality. Ripens very early; suitable for table and kitchen. Tree a vigorous grower and a good and regular bearer.

Red Bietigheimer. A-September. Hardy. Sour. Red, not striped. A valuable German variety. Fruit large, roundish, inclined to conical. Skin dark yellow, covered with purplish critison. Flesh white, firm, sub-acid, with a brisk, pleasant flavor. Tree a free grower and an coundant bearer.

Phode Island Greening. W-November to March. Sour. Green, not striped. Fruit largु?, roundish, often a little flattened. Color or. $\mathrm{n}$, becoming greenish yellow; always fair. Flesh yellow-a rich yellow if exposed much to the sun, and whitish yellow or greenish white if much shaded-tender, juicy, with a rich, rather acid flavor. Growth strong; young trees crooked. Very productive, single trees sometimes yielding 40 bushels of fair fruit in favorable years, and orchards 500 bushels per acre. Tender far west. Succeeding well in all northern sections and on a great variety of soils. A crooked growing tree in the nursery.

Rolfe. $A$-September and October. Hardy. Sour. Red, not striped. Tree a strong grower and annual bearer. Fruit large and handsome. Skin red on yellow ground. Flesh light color, subacid. Core small. Origin, Maine.

Rome Beauty. $W$-November to Febru. ary. Sour. Red, striped. Fruit large, roundish, very slightly conical. Skin mostly covered with bright red on pale yellow ground. Flesh tender, not fine-grained, juicy, of good quality. Ripens early in winter. The large size and beautiful appearance of this new Ohio Apple render it popular as an orchard variety.

Roxbury Russet. $W$-January to June. Sour. Yellow. Russet, not stripcd. Fruit medium to large, roundish, sometimes a little flat. Skin partly or wholly covered with rather rouch russet on greenish yellow ground, sometimes a dull brown cheek. Flesh greenish white, rather granular, slightly crisp, with a goad subacid flavor. Keeps late in spring, rommanding then a good price. Although not

the highest flavor, its productiveness, uniformly fair fruit, and long keeping quality, render this variety one of the most profitable for orchard culture. It succeeds well throughout the northern states, but partially fails in a few localities in the west.

Salome. $W$-Keeps until June. Extra hardy. Sour. Red, striped. Tree very hardy, healthy, vigorous and productive. Bears when young. Fruit medium size, roundish, conical.
Skin pale yellow, striped and shaded light and deep red. Flesh whitish yellow, tender, juicy, mild subacid, slightly aromatic; very good. A long keeper. A valuable new western Apple. Origin, Illinois.

Scott's Winter. $W$-Keeps until June. Extra hardy. Sour. Red, striped. A valuable variety which originated in Vermont, and is, like the Magog Red Streak, hardy in the severest climate; tree a thrifty grower; a young and profuse bearer. Fruit medium size, roundish. Surface deep red and light red in blotches and streaks. Flesh yellowish white, slightly reddened near the skin; rather acid and good in quality. Pronounced by Dr. Hoskins, of Newport, Vt., as his most profitable market Apple.

Seek-No-Further. $W$-October to February. Sour. Red, striped. Fruit medium to large, roundish. Skin obscurely striped with light dull red, more or less russeted, rarely covered with russet. Flesh white, fine grained, tender, with a rich, spicy flavor; quality very good. Tree productive, fruit always fair. It succeeds well in the northern states.

Senator. $W$-October to January. Sour. Red or Greenish Yellow, striped. The fruit is of medium size, smooth. Skin mostly red on a greenish-yellow background and with a red stripe. Its flesh is yellowish-white, stained with pink, with a small core. The fruit should be picked about October 1st. It seems to be an unusually good keeper.

Sherwood's Favorite. $A$-September and October. Sour. Yellow, striped. Fruit large, angular. Skin striped and splashed with light crimson on whitish yellow ground. Flesh white, juicy, very mild and tender, slightly subacid. Very much esteemed for the table. Origin, Chenango county, N. Y. Is named Chenango Strawberry by some.

Sops of Wine. $S$-August to September. Sour. Red, striped. Fruit medium size. Skin dark red. Flesh white, often stained, moderately juicy, subacid, of good flavor. An abundant bearer. Valuable for its free growth and fair fruit.

\section{Sour Bough. $S$-See Early Harvest.}

Snow. $A$-See Fameuse.

Smith's Cider. W-December to March. Sour. Red, striped. Fruit medium or rather large, roundish oblong, somewhat flattened at the ends. Skin shaded and slightly striped with light red on pale greenish yellow, with a few conspicuous whitish, yellow dots. Flesh whitish, tender, crisp, with a subacid, moderate flavor. Grown in Pennsylvania and the Ohio valley. Valued for its hardiness, productiveness, and handsome fruit.

Smokehouse. $A$-Middle of October to February. Yellow, striped. Fruit is above medium size, roundish. Skin yellow, shaded and splashed with crimson. Flesh yellowish, somewhat firm, 
juicy and crisp, rather subacid. Valuable for culinary purposes. Quality good. Tree moderately vigorous, and a good bearer. Succeeds in the middle states. Originated in Lancaster county, $\mathrm{Pa}$.

Spitzenburg (Esopus). W-December to March. Sour. Red, striped. Fruit medium size, slightly conical. Surface a high, rich red rather obscurely striped. Flesh yellow, firm, crisp, spicy, rather acid, and unequaled in its high rich flavor. Keeps through winter. Usually a moderate bearer. The tree is a poor grower in the nursery, and consequently less grown than others, but the quality of the fruit makes it a general favorite. Succeeds best in New York, its native state.

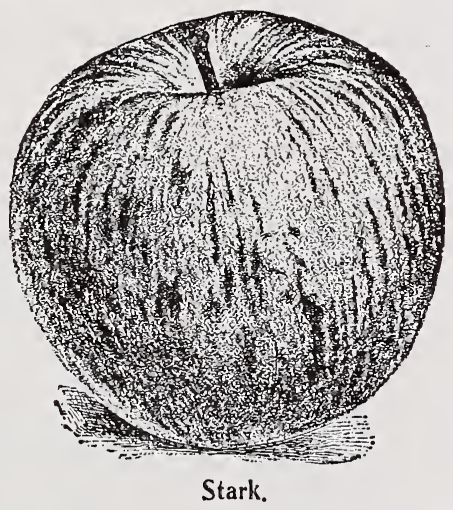

Stark. W-January to May. Sour. Red, striped. Tree a vigorous grower. Fruit large, roundish. Skin greenish yellow, shaded and striped with light and dark red nearly over the entire surface, and thickly sprinkled with light brown dots. Flesh yellowish, coarse, moderately juicy, mild subacid. Valuable as a keep. er. Origin, Ohio.

Stayman's Winesap. W-December to April. Sour. Red, striped. Fruit of medium size, round, slightly conical. Skin lively deep red. Flesh yellowish, firm, crisp, with a rich, rather subacid, flavor. A good, long keeper.

Steel's Red. W-See Canada Red.

Stump. A-August and September. Sour. Red, striped. Fruit good size. Color pale yellow, striped and splashed with bright red; exceedingly fair and beautiful, and of excellent quality. Tree a vigorous grower and an abundant bearer. Origin, Monroe Co., N. Y.

Sutton Beauty. $W$-December and January. Sour. Yellow, striped. Fruit large, roundish. Skin waxen yellow, striped with crimson. Flesh tender, subacid. Good tree; a free grower and productive. A valuable new Apple, that is proving as profitable as the Bald. win for orchard purposes. Origin, Worce: Mass.

Sweet Bough. S-Middle July to Aus 10. Sweet. Yellow, not striped. Fruit large size, pale greenish yellow. Flesh white, very ten. aer and crisp when fully ripe, with a rich, sweet flavor. Tree moderately vigorous; a moderate bearer. Désirable as an eating Apple.

Tallman Sweeting. $W$-November to March. Sweet. Yellow, not striped. Fruit medium size or rather large, round, slightly conical. Color clear, light yellow, with a clear, brownish, distinct line running from stalk to apex. Flesh quite white, rather firm, fine-grained, with a rich, sweet flavor. A very popular and productive orchard Apple, from the hardiness of the tree and its great productiveness. Keeps into spring.

Tetofsky. S-August. Sour. Extra hardy. Red, striped. Fruit medium size, nearly round. Flesh white, very juicy and acid. Fully as hardy as the Duchess of Oldenburg, producing regularly abundant crops of beautiful fruit. Succeeds over a large extent of country, especially desirable in high latitudes, where many other varieties fail by reason of the extreme cold. We consider it very desirable.

Tulpahocken. $\quad W$-See Fallawater.

Twenty-Ounce. $A$-October and December. Sour. Red and yellowish green, striped. Fruit very large. Surface sometimes smooth, often very wavy. Color, striped rich yellowish red on greenish yellow background. Flesh coarse-grained, sprightly, brisk, subacid. Very showy, fair and productive. A profitable mar. ket Apple. Origin, Western N. Y.

Wagener. W-December to March. Sour. Red, striped. Fruit medium size, roundish oblate. Skin shaded and indistinctly striped witis pale red and a full deep red in the sun on a

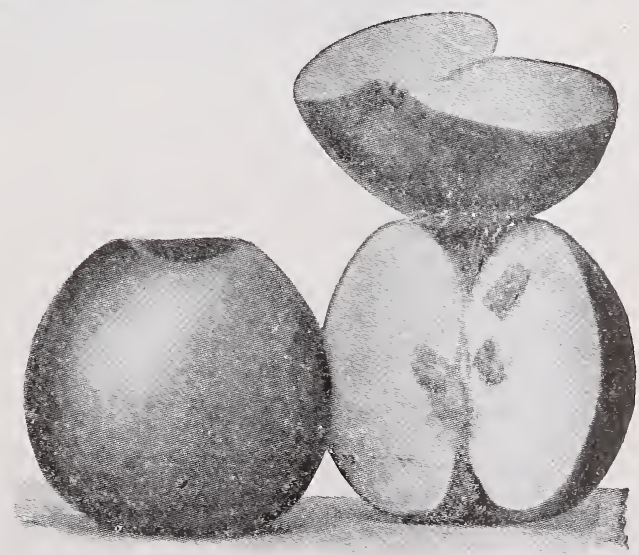

Sutton Beauty. 
warm, yellow ground; often steaked with russet. Flesh yellowish, fine grained, tender, compact, mild subacid, aromatic, excellent. Ripens through winter. Succeeds well at the west. Urigin, Penn Yan, N. $Y$.

Walbridge. W-February until May. Extra hardy. Sour. Red, striped. Fruit medium size, handsome, round-conical. Color pale yellow, with a pale red cheek. Quality good. Tree a rigorous grower and productive; hardy, and desirable for planting in northern sections, having stood uninjured in Minnesota. Ripens through late winter. Origin, Illinois.

Wealthy. $A$-November to January. Ex. tra hardy. Sour. Red, striped. Fruit medium size, roundish oblate, smooth. Color whitish yellow ground, shaded with dark, rich red, sometimes entirely covered with red. Flesh white fine grained, sometimes stained with red; tender, juicy, lively, subacid. Quality very good. Core small. A beautiful and excellent fruit. Tree extremely hardy; a good grower and an abundant bearer, and a remarkably profitable market Apple, bringing good prices. This Apple is sustaining a high reputation throughout the country on account of its great hardiness and good quality. Origin, Minnesota.

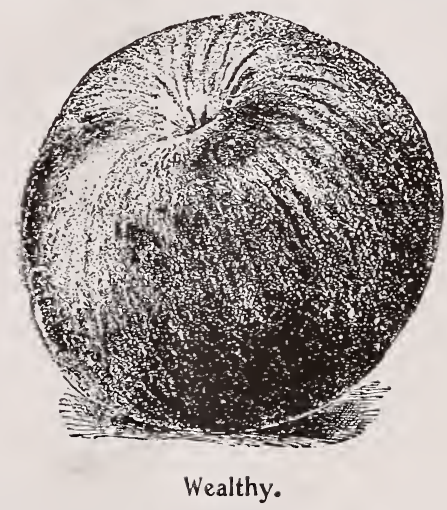

Willow Twig. W-April to May. Sour. Yellowish green, striped. Fruit large, roundish, slightly conical. Color greenish yellow, striped and mottled faintly with dull red. Flavor subacid or rather acid, not rich. A long keeper. Flesh firm, rather tough; a young bearer.

Wine Sap. W-December to April. Sour. Red, striped. Size of fruit medium, round, slightly conical, sometimes ol,scurely flattened. Color a lively, deep red. Flesh yellowish, firm, crisp, with a rich subacid or rather acid fiaror. Keeps through winter. One of the best apples for loking. Very good.

Winter Banana. W-Sour. Yellow and red. Prof. L. H. Bailey, of Cornell University, writes in regard to this apple: "The quality of the Winter Banana is very excellent and it has a spicy flaror which I like rery much. If the Apple is productive and hardy, and has the quality. which the specimen seems to indirate, it is certainly very valuable."
Prof. L. R. Taft, of Michigan Agricultural College, writes:

"While not very large, the Winter Banana is of good size, regular in form and beautiful and handsome in appearance. Unlike most other sorts of its color it seems to handle well, the specimen that I have not showing any discoloration after being handled a number of times. In flavor it is a very mild subacid with a rich, aromatic odor and flavor. If sufficiently hardy would consider it a very valuable Apple for either home use or market."

White Pippin. W-January to March. Sour. Greenish yellow, not striped. Fruit large, roundish oblong, flattened at ends. Color light, greenish yellow. Flesh yellowish white, subacid. Good, but not very rich. Tree a vigorous grower and bearer.

Wolf River. $W$-January to February. Ex. tra hardy. Sour. Red, striped. One of our hardy varieties that may, without doubt, be classed as an "ironclad." Tree a strong grower, great bearer and perfectly hardy. Fruit large, conical. Color yellowish white, splashed with bright red; dots large, scattering, light gray. Flesh yellowish white, coarse, tender, dry when ripe, subacid, not rich, medium quality only. Valuable in the northwest. Originated near Wolf River, Wisconsin.

Yellow Transparent. $S$-July and August. Sour. Extra hardy. Yellow, not striped. Russian variety, imported by the Department of Agriculture, Washington, D. C. Tree hardy and a strong grower, and an unusually young bearer. Fruit good size and good quality. Skin clear white at first, turning to a beautiful pale yellow when fully ripe. Flesh white, alf fine, tender, juicy, sprightly subacid. Core medium. Parties who have fruited it extensively north and south say that it ripens earlier than any other variety, being ten days to two weeks ahead of Early Harvest. Exceedingly valuable as an early marketvariety, and of our summer or early apples we rank it as the best.

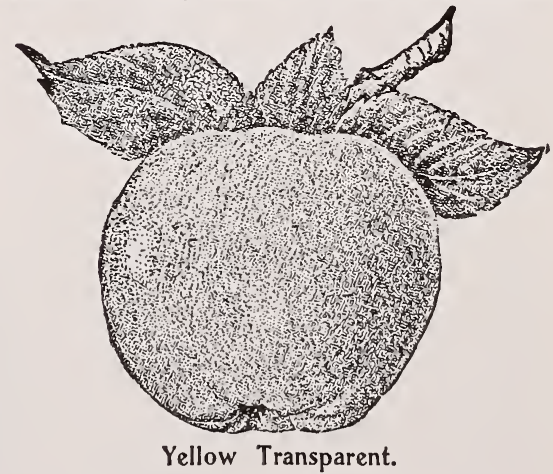

York Imperial. $W$-November to Febru. ary. Sour. Red, not striped. Fruit medium. Color whitish, shaded with crimson in the sun. Flesh firm, crisp, juicy, pleasant, mild subacid. Tree moderately vigorous and productive. 


\section{SELECT CRAB APPLES.}

$T^{\mathrm{H}}$

HESE varieties are entirely hardy, and while they will endure the greatest degree of cold, the will also thrive equally well in the Middle or Southern states. Crai fruit is valuable for cider, preserves and canning, and some of the improved varieties are pleasant and rich for the 3 dessert. Crab fruit is profitably grown for market.

Excelsior. Extra hardy. Red, striped. October. A valuable seedling of Mr. Gideon's, raised from the seed of the Wealthy, which is already known as one of the handsomest, hardiest and best flavored of our newer fruits, and it partakes of many of the best characteristics of the parent variety. Ripens in early fall, a little later than the Duchess of Oldenburg. Size of fruit about that of Fameuse, and very handsomely colored; is a shade or two lighter than the Wealthr, while it closely resembles it in quality and in the form and growth of the tree.

General Grant. Extra hardy. Red, striped. October and November. Fruit large, round. Color vellow, covered with stripes of red, and when exposed to the sun turning quite dark. Flesh white, fine grained, mild subacid. Tree a good grower, hardy and productive. In season during late autumn.

Hyslop. Red, not striped. Nov. ember. Fruit large, roundish ovate, and produced in clusters. Color dark, rich red, covered with thick blue bloom. Flesh inclined to yellow, subacid. Tree very hardy and vigorous.

Martha. Red and yellow, not striped. October and November. A new crab raised from the seed of the Duchess of Oldenburg by P. M. Gideon, of Minnesota. Mr. Gideon says: "A rapid, stiff grower, a perfect pyramid in form ; a great bearer of the most beautiful fruit we erer grew; a bright, glossy yellow, shaded with light, bright red; a mild, clear tart, surpassing all other crabs we ever grew for all culinary purposes, and fair to eat from hand." We regard it as very valuable.

Transcendent. Red-yellow, not striped.
September to October. Fruit medium size tic large, roundish oblong. Color golden yellow: with a rich, crimson-red cheek, covered with a delicate white bloom; at ripening, the rec nearly covers the whole surface. Flesh yellow,;

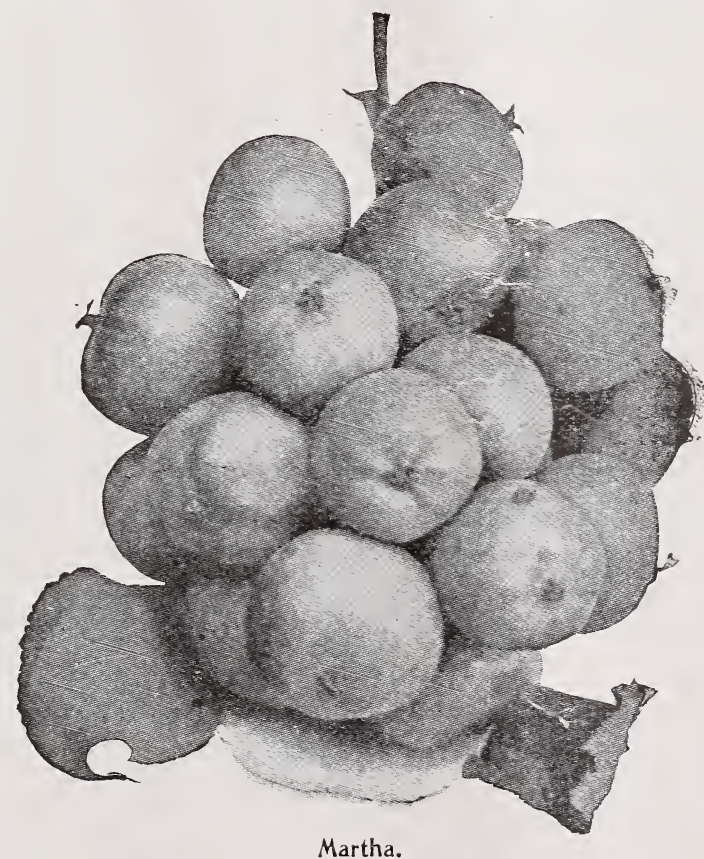

crisp, and, when fully ripe, pieasant and agreeable. In season early in autumn. Tree perfectly hardy and a young and abundant bearer.

Whitney. Red, striped. August. Fruit: of medium size. Skin smooth, glossy green, striped and splashed with carmine. Flesh firm and juicy, and flavor very pleasant. A great bearer and very hardy, as well as a rigorous, handsome grower. Origin, Illinois. 


\section{SELECT PEARS.}

\section{THOROUGSILY TESTED VARIETIES THAT HAVE PROVED VALUABLE.}

$\mathrm{G}^{\mathrm{A}}$ ATHERING PEAKS-Nearly all Pears should be picked from the tree before maturity, and ripened in the house. Summer Pears should be picked at least a week or ten days before they are ripe. Autumn Pears two weeks before they are ripe. Winter Pears should be picked before there is any danger of frost.

When the tree bears abundantly, it is best to thin the fruit well when it is about one-third grown; the remaining specimens will be greatly improved.

Under a separate head, on page 14, will be found a list of varieties that thrive as Dwarf Pears ; that is, they do well grown upon French quince stock for their roots.

RIPEAING - The season of the year when the fruit is fully ripe and at its best to use, is indicated by the letter $\mathrm{S}$ for summer season, $\mathrm{A}$ for autumn season, $\mathrm{W}$ for winter season, together with the particular months of that season. This is the time of maturity in the western part of New York State; will vary north and south.

\section{STANDARD PEARS.}

Bartlett. $S$-August and September. Fruit quite large, sumewhat pyramidal in shape. Surface yellow, with a faint blush. Flesh nearly white, fine-grained, tender and buttery, with a nearly sweet, sometimes faintly subacid, rich flavor. Ripens end of summer and beginning of autumn, far north is strictly an autumn Pear. The fruit, when not fully grown, ripens and becomes of good quality if kept in the house a week or two. Tree very productive, bears very young. Hany fine qualities render it a general favorite. Succeeds over a large extent of territory.

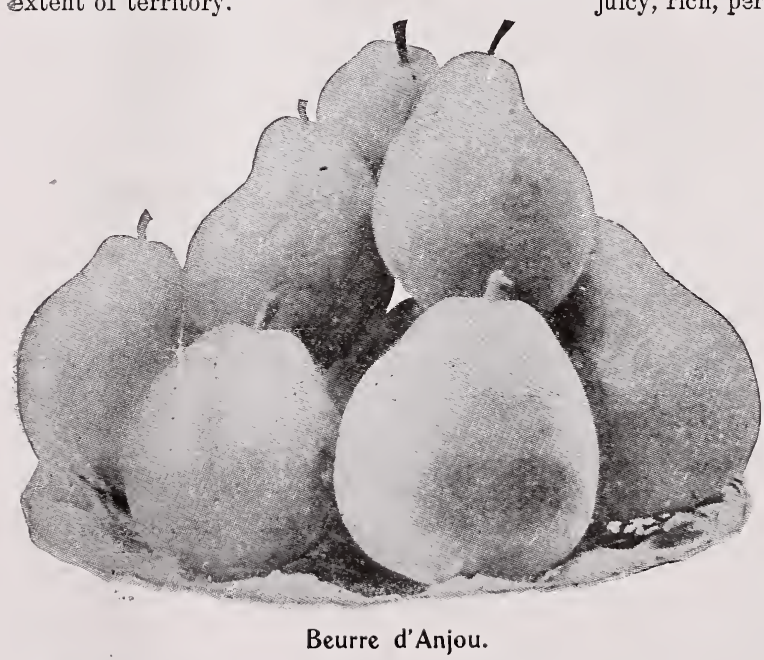

Bartlett-Seckel. A-Season September. A cross between Bartlett and Seckel, and combines in itself the richness and high flavor peculiar to those well-known varieties. Fruit medium size. High color and handsome. Tree very vigorous, hardy and productive. Origin, Rochester, N. Y.

Bessemianka. A-Season September and October. Fruit medium size; form obovate. Color yellow-crimson. Flesh buttery, melting, juicy, sweet, perfumed. Quality fair to good.

Beurre Bosc. A-September and October. A large, deep yellow Pear, russeted in patches. Tree a moderate grower. Fruit body broad, neck long, and very narrow. Flesh juicy, rich, perceptibly perfumed, sweet. Bears well. We usually top-graft in order to obtain good standard trees. It does not succeed as a Dwarf tree.

Beurre Clairgeau. $W$ November and December. The flesh is inclined to be a trifle coarse and granular on strong, moist soil, but in a rich, warm spot is far superior. The tree is a strong, shapely grower, making a beautiful pyramid. It should be grown as a Standard, not as a Dwarf. Fruit very large. Skin yellow or yellowish brown, often with a crimson shade toward the sun, and brown dots. Flesh white, slightly granular, buttery, melting, often with a rich, very good flavor. A young and abundant bearer. From its handsome appearance and productiveness, it is a good market variety.

Beurre a'Anjou. $A$-November to De. cember. Hardy. A large, handsome Pear. Surface greenish yellow, a dull red cheek to the 
sun, clouded with russet. Flesh yellowish white, fine-grained, buttery, melting, with a high, rich, vinous, excellent flavor. Tree a good bearer. The hardiness, uniformity, reliability, excellence and long-keeping qualities render it one of the most valuable of all Pears. Begins to ripen in the middle of autumn, and keeps until the winter holidays, when it commands a very high price in market.

Clapp's Beauty, or Clapp's No. 64. $W$-December and January. Fruit medium to large, obovate-pyriform. Skin greenish yellow, with distinct red cheek. Flesh sweet, tender, fine-grained, good. Tree vigorous, hardy and productive. A new and valuable winter Pear

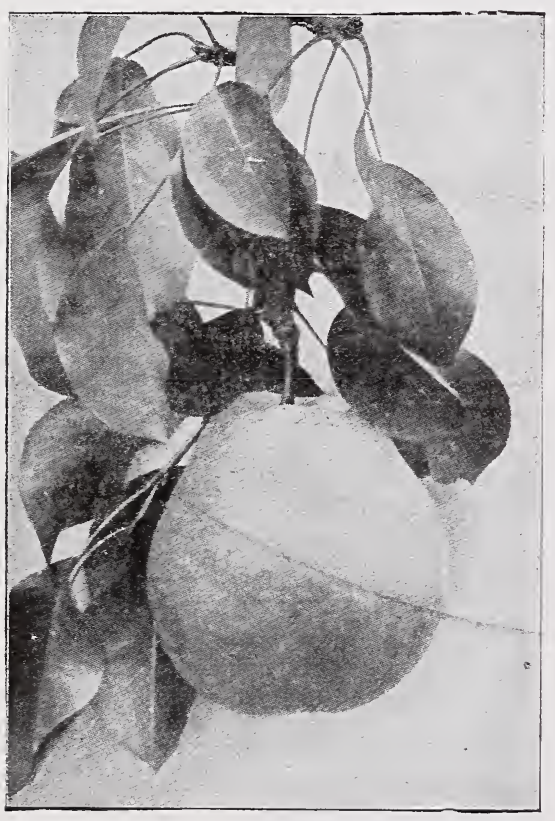

Derchess d'Angouleme.

Clapp's Favorite. $S$-Late August to Early September. Extra hardy. Supposed to be a cross between Bartlett and Flemish Beauty. Fruit of large size, tapering to the crown, neck rather small. Skin smooth, yellowish green, becoming yellow, dotted and shaded with red to the sun. Flesh greenish or yellowish white, juicy, melting, perfumed, of very good quality. Ripens the end of August and early September, or about a week before Bartlett. Fruit uniform size and evenly distributed over the tree. Equally hardy with Flemish Beauty, also a good grower and productive. Pick the fruit at least ten days before it would :ipen upon the troe. Origin, Dorchester, Mass.

Duchess d'Angciseme. A.-October and November. Should only be sold as a dwarf. Fruit very large. A rougn and uneven surface. Color a greenish yellow, with patches of russet and a dull red cheek. Flesh yellowish white, melting, buttery, juicy. A vigorous and strong grower, and a good bearer while quite young. Valuable for orchard. It attains its greatest perfection on the quince root, or as a dwarf tree.

Duchess de Bordeaux. $W$-November to January, Fruit medium size. Color greenish yellow. Flesh juicy, sweet. Productive.

Doyenne d'Ete. $S$-Season August. Fruit small. Color yellow, blush on the sun side. Melting and sweet, pleasant flavor. Tree a strong grower, productive.

Eastern Belle. $A$-September. Extra hardy. Probably a seedling of the Belle Lucrative. Fruit medium size. Yellow, shaded with light red, and some russet. Juicy, half melting, sweet and rich, with peculiar musky perfume. Excellent quality : very hardy and an abundant and regular bearer. Origin, Maine.

Flemish Beauty. A-September and Oc. tober. Extra hardy. Fruit iarge; shape varies. Surface slightly rongh, wich some reddish brown russet on pale yellow ground. Flesh juicy, melting, often with a rich, sweet, and excellent flavor, but variable, and sometimes not high-flavored; needs house-ripening. An old and highly esteemed variety; a strong grower and great bearer. Hardy and desirable. This variety ranks for hardiness among Pears as the Duchess of Oldenburg does among apples-with the most hardy.

Frederick Clapp, or Clapp's No. 22. $A$. -Middle to last of October. Fruit medium to large size, inclined to roundness, but variable in form. Skin smooth, bright yellow, without blush or russet, but has many minute brown dots. Flesh whitish yellow, very juicy. Quality very good to best. A remainably goodkeeper. Tree vigorous and an abundant bearer. Origin, Dorchester, Mass., on the same farm as the Clapp's Favorite.

Howell. A-September and October. Fruit rather large, sometimes short, obscure neck. Color light waxen yellow, handsome cheek, with minute dots. Fruit sweet and melting, of excellent quality. Tree a strong and hardy grower and good bearer. Extensively planted all over the country. Origin, Connecticut.

Idaho. A-October. Tree vigorous, having dark, luxuriant foliage. Fruit large size, roundish, flavor pleasant. Flesh entirely free 
from gritty texiure; core small, and often without seeds. A good shipper. Origin, Idaho.

Kieffer. A-October and November. Raised from the seed of the Chinese Sand Pear, supposed to have been cross-fertilized with some

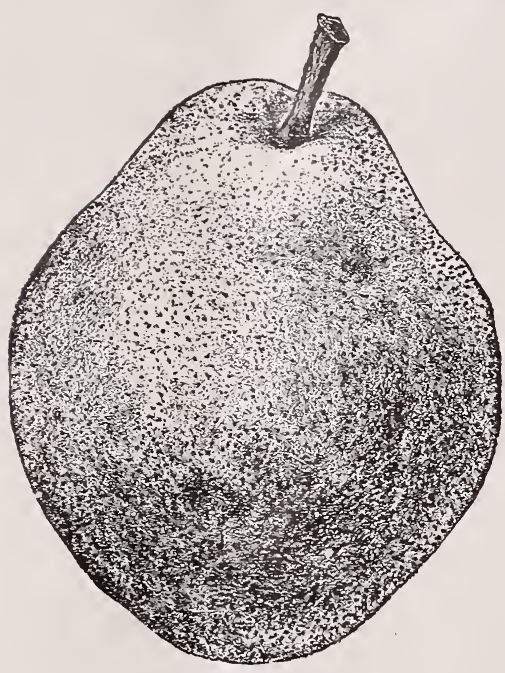

Kieifer. (Half size.)

other kind grown near it. Tree remarkably vigorous, having large, dark green, glossy leaves, and is a young and very heavy bearer. The tree is inclined to overbear, and proper thinning will improve the quality of the fruit. Fruit large to very large, roundish oval, narrowing at both ends. Skin rich golden yellow, with a fine red blush on the sunny side. Flesh is whitish, a little coarse, juicy, very good. Ripens through October and November. To have it in perfection, ii should be gathered when fully grown and ripened in the house. As a canning Pear, it retains its light color and possesses a rich, vinous flavor, being very refreshing, and, notwithstanding the process of canning, it remains rich, juicy and sprightly.

Koonce. $S$-Season last of August. Fruit medium to large. Color golden yellow, red cheek; handsome. Flesh spicy, juicy, sweet, good quality. Season very early. Tree vigorous, free from blight. Origin, Illinois.

Lawrence. $\quad W$-December. Fruit above medium size. Color lemon-yellow, numerous small dots. Flesh whitish, buttery, rich, very good flavor. A young and good bearer, and unexcelled as a valuable early winter sort. Ripens easily, and is of uniform excellence.

Louise Bonne de Jersey. A-September and October. Large, tapering. Pale yellowish green in the shade, but overspread with brownish red in the sun. Very juicy and melting, with a rich and excellent flavor. A profitable market variety. Succeeds better as a Dwarf tree than on the Pear root. While hardly of the highest quality, it is very valuable for its large, fair fruit and great productiveness.

Manning's Elizabeth. $S$-Late August. Bears in clusters. Fruit small to medium. Crimson and gold color; beautiful. Flesh melting, rich, sugary, sprightly, perfumed flavor, productive. One of the best early Pears.

New England Beauty. A-November. Fruit medium size. Flesh white, tinged with orange; very juicy. Skin yellowish russet, with red cheek. Tree a vigorous, upright grower, productive. A valuable market sort.

Osband's Summer. $S$-Ripens early August. Fruit medium in size, often rather small. Greenish yellow, becoming yellow, with a reddish russeted cheek. Flesh white, granular, sweet, fine flavor; soon loses its flavor

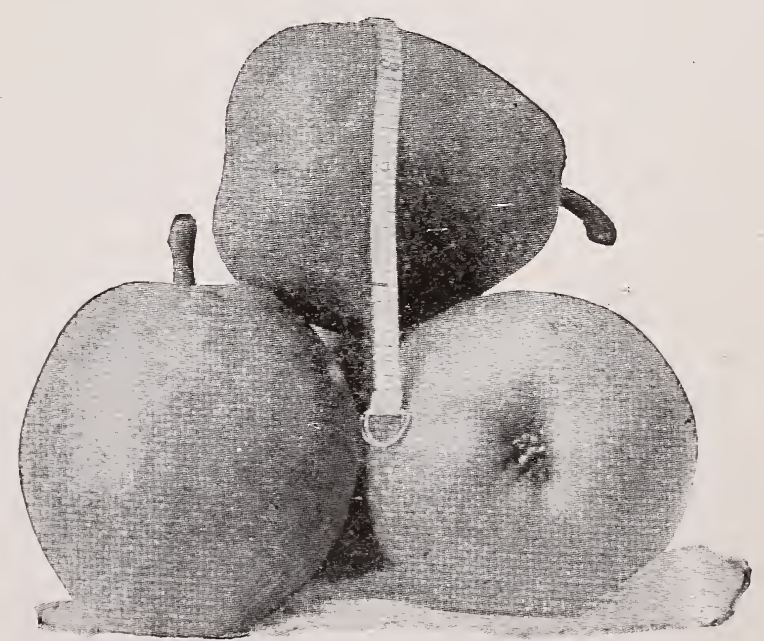

Sheldon. (See page 13.! 
when mature. Tree moderately vigorous, and very productive. Origin, Wayne county, New York.

President. $A$-November. Very large, handsome Pear. Color greenish yellow, with red in the sun. Flesh juicy, with an agreeable vinous flavor.

President Drouard. W-March to May. A variety recently introduced from france, highly recommended for its rich flavor and great keeping qualities. Tree a vigorous grower. Fruit large and handsome ; melting and juicy, with a delicious perfume.

Rutter. $A$-October and November. Fruit medium to large, nearly globular. Skin rough, greenish yellow, sprinkled with russet. Flesh white, moderately juicy, nearly melting, sweet, slightly vinous. Good quality. Tree an upright grower and a young and abundant bearer. American origin.

Seckel. $A$-September and October. Fruit small. Skin rich yellowish brown, with a deep brownish red cheek. Flesh very fine grained, sweet, very juicy, melting; onc of the richest and highest flavored Pears known. Tree very hardy, and remarkably free from blight. A prolific bearer. Valuable as a market variety, the fruit bringing good prices. Needs rich cultivation. Origin, near Philadelphia, $\mathrm{Pa}$.

Sheldon. $A$-October and November. A Pear of the very first quality. Fruit large, roundish. Color greenish russet. Flesh very melting, juicy. Tree vigorous, erect and handsome and bears well when grown on pear root (as a Standard). A fine grower and good bearer, of fine quality, but does not succeed grown on the quince root (as a Dwarf). Should be sold only as a Standard.

Tyson. $S$-Late August. Fruit above size. Bright yellow, with a reddish russet, softly shaded cheek. Flesh of fine texture, buttery, melting, juicy; flavor nearly sweet, slightly perfumed. The tree does not soon come into bearing. Origin, Pennsylvania.

Vicar of Winkfield. $W$-November and December. Fruit quite large, long, tapering. Skin pale yellowish green, dull reddish cheek. Flesh greenish or yellowish white, juicy. Its great and uniform productiveness, fine qualities for cooking, and long period of continuance, render this a valuable Pear.

Vermont Beauty. $W$-October. Fruit of medium size. Color yellow, with bright carmine cheek. Flesh rich, juicy and subacid. The tree bears young, is of vigorous growth, and very productive. Originated in Grand Island county, one of the northernmost and coldest counties of the state of Vermont.

Wilder.' $S$-One of the very earliest. Hardy. Produces a crop while young. Fruit large, pyriform, very highly colored, pale yellow, shaded dark russet red; small, numerous dots. Flesh pale yellow, fine-grained, juicy; flavor above medium to very good. Good shipper, and tree a very prolific bearer. Good for market. A report from the state of Vermont, where the mercury goes far below zero, is that the Wilder has come through their severe winters alive and bright to the tip.

Worden-Seckel. A-October to Decem. ber. A seedling of the Seckel. Color golden yellow, one side bright crimson. Flesh dull white, very juicy, buttery, melting, fine-grained with a flavor and aroma fully equal to that of its distinguished parent, which it far surpasses in size, beauty and keeping qualities. Ripens early in October, and can be kept in good eating condition till December. Bears in clusters,

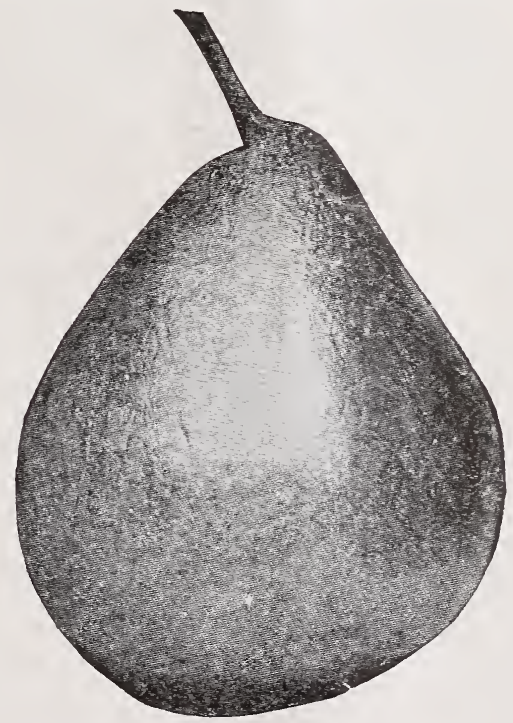

Worden-Seckel.

and is one of the most beautiful and attractive, and at the same time one of the best flavored Pears on the market. Prof. I. P. Roberts, of Cornell University, president of the New York society, says :

"The Worden-Seckel is certainly a very beautiful Pear. I consider this a very valuable variety and well worthy a place among the best in the country."

The Syracuse Journal says, in part:

"There is no more toothsome Pear than the Seckel, and that it has been improved upon is a distinct point gained. The Worden-Seckel is a delicacy. It is a little beauty, and as palata. ble as handsome. The Pears are perfect, high colored and luscious to the taste."

Originated by Mr. Sylvester Worden, of Minetto, Oswego county, N. Y., the originator of the noted Worden grape. We highly recom. mend Worden-Seckel. 


\section{SELECT DWARF PEARS.}

THE Pear, when budded upon the root of the quince, assumes a dwarf habit, and seldom grows above 10 feet in height when properly trained.

In planting Dwarf Pear trees the stock on which they are budded, and no more, should be under ground. They will then stand firm, and not lose their dwarf character by the rooting of the standard stock. The side branches should not be removed higher than one foot from the ground on dwarfs. Train in pyramidal form.

See directions under Standard Pears for gathering and ripening Dwarf Pears.

The selection of varieties in the Dwarf sorts is of importance, and it is a well established fact that certain kinds do not thrive well on the quince root. Our list includes the varieties valuable as Dwarf trees.

\section{Summer Varieties.}

$\begin{array}{lll}\text { Bartlett, } & \text { Flemish Beauty, } & \text { Osband's Summer, } \\ \text { Clapp's Favorite, Manning's Elizabeth, } & \text { Tyson, }\end{array}$

Wilder.

\section{Autumn Varieties.}

Beurre d'Anjou,

Howell, Louise Bonne de Jersey, Seckel,

Duchesse d'Ångouleme,

Kieffer, Rutter,

Vermont Beauty.

\section{Winter Varieties.}

Lawrence,

President Drouard, Clapp's Beauty,

Worden-Seckel,

Vicar of Winkfield.

The description of the fruit of the Dwarf Pear tree is identical with that of the fruit of the Standard Pear tree. 


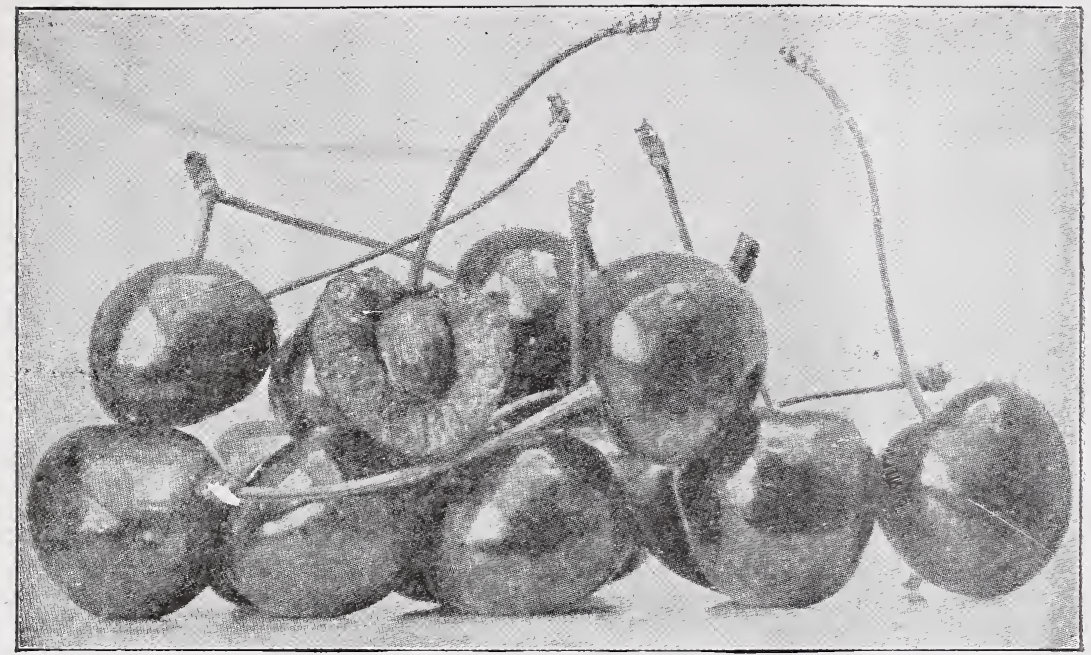

Schmidt's Bigarreau Cherry.

\section{SELECT CHERRIES.}

Bessarabian. Sour. Dark red. The new, hardy, Russian Cherry. The following description is by Professor Budd, of the Iowa Experiment Station :

Fruit large. Dark red. Firm fleshed, and when ripe, very mildly subacid. It promises to make a long-lived tree of considerable size, and to prove a regular bearer of choice fruit.

Black Eagle. Sweet. Dark. Early in July. Fruit rather large; roundish, heart shaped. Skin deep purple, nearly black. Flesh deep purplish crimson, tender, rich and highly flavored. A moderate bearer.

Black Tartarian. Sweet. Black. Early to middle of June. Fruit quite large (often an inch in diameter), heart shaped, with an uneven surface. Skin bright black. Flesh dark, half tender, with an excellent liver-like consistency, rich, very little acid, with a fine, mild flavor. The vigorous growth and great productiveness of the tree, and the large size and mild, sweet flavor of the fruit, render this variety a general favorite.

Dikeman. Sweet. Dark. Ripens in Michigan Early in August. We get the following description from a well known horticultural authority :

The latest dark colored Cherry of medium size that I have ever seen. Origin, Michigan. Not inclined to decay, and keeps in perfect condition long after being picked. Its firm flesh and fine keeping qualities especially commend it as an orchard fruit. As seen growing on the original tree in Michigan, it is very productive. As grown in the state of Michigan I have found it ripening in early August, and hanging in perfect condition on the tree until late in the month.
Early Richmond. Sour. Red. June. Fruit medium size, round, growing in pairs. Flesh very juicy and acid. Tree slender; not a rapid grower, but a great bearer. This is one of the most popular of acid Cherries for hardiness and for cooking purposes. Ripens early, and hangs long on the tree.

English Morello. Sour. Dark red. Late July and early August. Fruit large. Color dark red, nearly black. Tender, juicy, subacid. Tree dwarf and slender.

Governor Wood. Sweet. Light. Middle of June. Fruit large, roundish, heart shaped, light yellow, shaded and marbled with light red. Flesh rather tender, nearly sweet, rich, excellent. Tree vigorous, forming a round head. As the trees grow older they often overbear, and yield a smaller and less excellent fruit; hence, require thinn:ing. Origin, Cleveland, Ohio.

Louis Phillippe. Sour. Red. Middle to last of July. Fruit large. Color rich dark red. Flesh red, tender, juicy, with a mild subacid flavor. Extra hardy; a vigorous grower and very productive. Origin, French.

May Duke. Sour. Dark red. July. Fruit large, heart shaped. Color red at first, becoming when mature nearly black. Flesh reddish, becoming dark purple, very juicy and melting, rich, acid, excellent. Usually early, but varies in its season of ripening, even on the same tree. Very hardy.

Montmorency Large. Sour. Red. Late June. One of the very finest acid Cherries, 
Tree very hardy and an immense bearer ; commences to fruit while young, and is loaded annually thereafter with fine crops. Fruit of

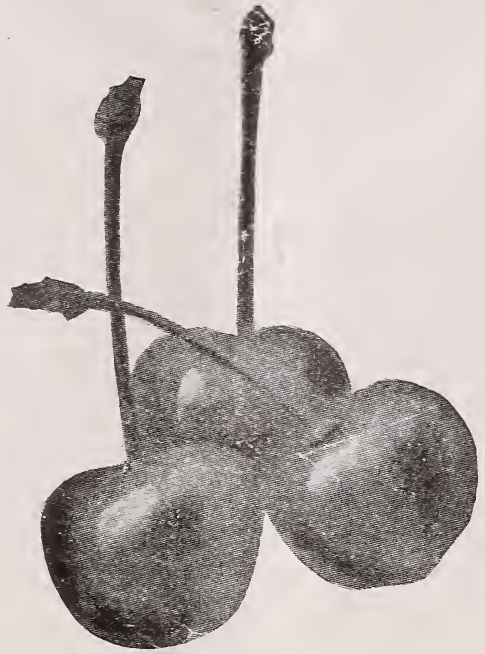

good size. Fine flavor. Color bright, clear red. Valuable everywhere, especially for northern latitudes. A good market variety. The Connecticut Valley Orchard Co., of New Britain, report through their Mr. J. B. Smith:

We have 50 trees (Large Montmorency Cherry) that came in to bearing last season and greatly like the variety. Is large, of high color, late, sour, and very productive. A fine tree, bearing its fruit not in clusters, but singly, and they grow so thick that they can be picked cheaper than any other Cherry we have.

Napoleon Bigarreau. Sweet. Light. Early in July. Fruit of the largest size, regularly heart-shaped. Skin pale yellow and amber, spot. ted and shaded with deep red. Flesh very firm, with a fine flavor. Very productive and good for market.

Olivet. Sour. Red. Continues fruiting through most of June and July without losing quality. A shining deep red. Fruit large. Flesh red, rose-colored juice, rich, vinous, with mild, subacid flavor. French origin.

Ostheim (Russian Cherry). Sour. Dark red. Early to middle of July. Imported from St. Petersburg, Russia. In the severest winters of Minnesota found to be hardy. Fruit large, roundish. Flesh liver color, tender, juicy, subacid, and when fully ripe nearly sweet.

Rockport, Sweet. Light. Late June and early July. Fruit quite large, round, heartshaped. Color, when fully ripe, a beautiful clear red, shaded with pale amber. Flesh firm, juicy, sweet, rich, with an excellent flavor. Tree upright grower. Origin, Cleveland, Ohio.

Schmidt's Bigarreau. Sweet. , Black. Middle of July. A most promising Cherry Fruit of immense size. Color a rich, deep black; very desirable for the table. Flesh dark, tender, very juicy, with a fine flavor. Tree bears abundantly. A Utica, N. Y., fruit commission merchant writes us about fruit of Schmidt's Bigarreau Cherry.

What about those nice dark cherries that you shipped me last season? Will you have any of them this season? If so would like to have you send them along." $8 \mathrm{lb}$. baskets sold for $75 \mathrm{c}$.

Stuart Bigarreau. Sweet. Light red. Late July. A new seedling Cherry, two or three weeks later than other varieties. Color a showy, light red. Fruit good size. Tree a vigorous grower and hardy, and extremely productive, making it very desirable for family use or market purposes. Our attention was first called to this Cherry by noticing baskets of it in a canning establishment, and while other varieties were all gone, this was still perfect fruit. The original tree has fruited each season for the last twenty years. On our Stuart Bigarreau Cherry fruit a commission merchant wrote us:

"Would be pleased to receive some of those elegant Sweet Cherries you shipped me last season."

This man sold Stuart Bigarreau fruit for us selling $8 \mathrm{lh}$. haskets at 75 cents per basket.

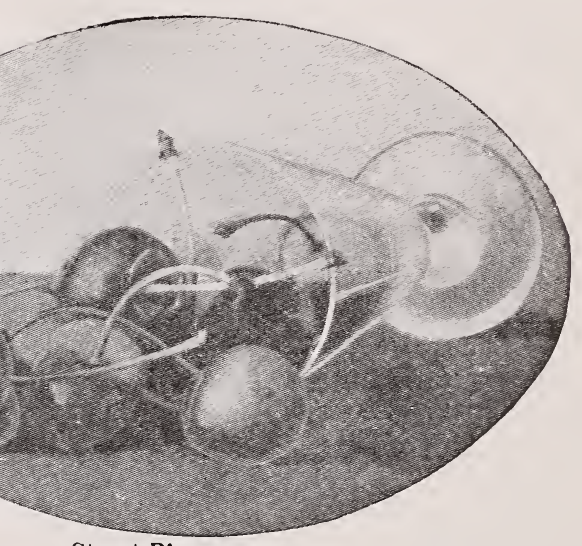

Stuart Bigarreau.

Windsor. Sweet. Dark. Late July. Fruit large. Color nearly black, or liver-colored. Flesh remarkably solid, sweet, and of a fine quality. A very valuable late winter variety for market and for family use. Tree hardy and very productive. A seedling originated in Windsor, Canada.

Yellow Spanish. Sweet. Light. End of June. Fruit lasio, uften an inch in diameter. Pale waxen yellow, with a handsome, light red cheek to the sun. Flesh firm, juicy, rich and delicious. Tree vigorous and an excellent bearer. Succeeds over large extent of country. 


\section{SELECT PLUMS.}

\section{A List of Thoroughly Tested American, European and Japancse Varieties.}

Abundance. Japanese. Orange-yellow and red. Early September or late August. Imported by Luther Burbank in 1884. Fruit medium size (or large when thinned), varying in shape from nearly spherical to distinct sharppointed, usually with a pointed apex. Ground color rich yellow, overlaid on sunny side with dots and splashes of red, or in some specimens nearly uniformly blush-red on the exposed side. Flesh deep yellow, juicy and sweet, of good quality when ripe. Cling. A strong grower and upright tree, with rather narrow leaves, and a decided tendency to overbear. One of the sweetest and best. Fruit very thin-skinned with tender, melting flesh. This is one of the best known of all the Japanese Plums in the North, and its popularity is deserved. Is called True Sweet Botan by some.

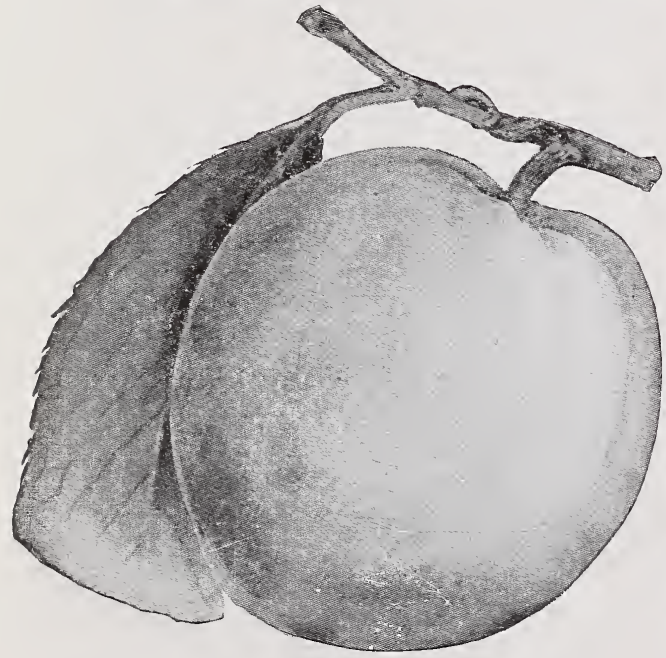

Abundance.

Apple. New. Japanese. Deep reddish purple. September and October. American origin. Procured from Luther Burbank, the "Wizard of Horticulture," who thus describes it :

Among the welcome surprises found three years ago among a lot of some twenty-five thousand Plum seedlings was this one, bearing a cruel load of enormous Plums when only two years old. It was at once named Apple, from the very close resemblance in form, color, general appearance, and rare keeping qualities. The tree is a fine, strong grower. The fruit averages about $21 / 2$ inches in diameter, is striped and mottled until nearly ripe, when it turns to a deep, reddish purple. The superlatively rich, high-flavored, sweet or subacid flesh is rather firm, pale red, with marblings and streaks of pink; nearly freestone. Ripens here (California) soon after Burbank, and sometimes keeps a month or more in lgood condition.
America. New. Japanese. Bright, glossy red. September. American origin. Procured from Luther Burbank, who describes it:

In growth and general appearance the tree is like the American Plums, is a good grower and exceedingly prolific. The fruit of America is larger than the average Japan Plums, and from four to sixteen times as large as the popu. lar American varieties. The glossy, coral-red. fruit is not surpassed in beauty by any Plum. The light yellow flesh is moderately firm and. very delicious ; so good that those who do not like most Plums call for more, and keep right on eating Americas. It ripens here (California) July 20, two or three weeks before Burbank, and is a splendid keeper. Will probably prove hardy throughout the United States.

Bartlett (Plum). Japanese family. Dull purplish red. August and September. Fruit oval or heart-shape. Flesh yellowish. A creation of Prof. Luther Burbank, who states :

"Who would believe that a Plum could ever be produced which would in quality flavor and fragrance be exactly like the ever popular Bartlett Pear? Yet such are the facts of the Bartlett Plum, which is Eo much superior to the Bartlett Pear in its own peculiar fragrance and flavor, that no one will ever eat the Pear if this Plum is at hand, and better $y$ et the plum bears the second season and will produce more fruit in ten years than than the Bartlett Pear will in twenty,"

"In reality a plum but in quality almost the exact counterpart of the Pfar from which it is named."-Santa Rose Republican.

Origin, California.

Beauty of Naples. Light. Season Sep. tember. Tree a good bearer. Color yellowish green, with reddish cheek on sun-exposed side. Flesh yellow-amber, tender, juicy, sweet, of excellent quality. Semi-cling. Fruit of medium to good size.

Bradshaw. Purple. Late August. Fruit very large, sometimes with a very slight neck. Color dark purple, with a light blue bloom. Flesh a little coarse, becoming light brownish purple, at first adhering, but becoming nearly free from the stone when fully ripe; juicy, good, slightly acid. Tree vigorous and productive.

Burbank. Japanese. Red. September and October. Imported by Luther Burbank in 1885 . Of the Japanese sorts, this is one of the best. Fruit when fully grown is 6 to 7 inches in circumference, nearly globular, often a little lopsided, point generally blunt. Color cherry-red, showing many yellow dots; often more or less marbled, in the sun becoming rather dense red. Flesh firm and meaty, deep yellow, rich and sugary; its firmness makes it a good keeper and a good shipper, and it is excellent for canning. For market or family use it is very fine. Tree of great vigor, with a broad, sprawlinghabit, needing close pruning; is exceedingly productive, and as it usually sets too much fruit, it should be thinned for best results.

"Ripe Burbank Plums kept in good condition 
for thirty-six days after-received. This speaks volumes for this "excellent variety."-North American Horticulturist.

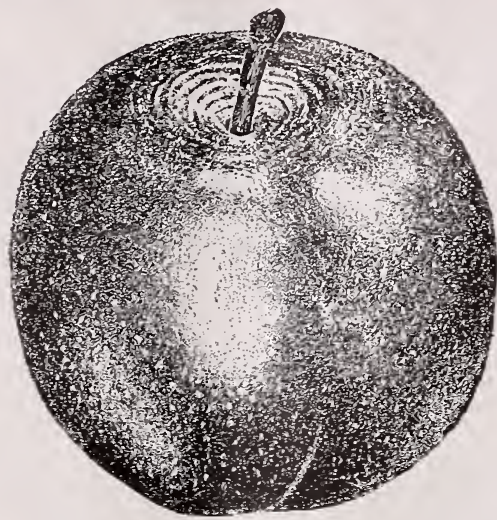

Burbank.

Chabot. Japanese. Yellow and red. Sep. tember. Fruit of medium size, oblong conical. Color bright, cherry red nearly all over, with yellow dots, excepting the shady side, which remains yellow. Filesh orange yellow, firm, juicy, sweet and of excellent quality. A cling. Valuable for drying and canning. Its late season of ripening and its beauty give it high market value. Tree strong, upright, and very productive. This variety is called Yellow Japan; also Chase by some. Is called Yellow Japan by some.

Chalco. New. Japanese. Deep reddish purple. September. Procured from Luther Burbank, who describes it thus:

After twelve years of experiments in crossing the unique, handsome, fragrant Chinese Plum, Prunus Simoni, often called the "Apricot Plum," with the Japanese and American Plums we now offer the first fruit of this long and very expensive work. The fruit, which ripens just before the Burbank, is large, flat like a tomato, deep reddish purple, with very sweet, rather firm, exceedingly fragrant, yellow flesh and small seed. Like the Apricot Plum, the fruit is almost as stemless as a peach, and completely surrounds the older branches as thick as it can stick, like kernels on a huge ear of corn. A superior shipping Plum, as it ripens well when picked green, and keeps nearly or quite a month. A tremendous grower, and unsurpassed in productiveness. Chalco is a forerunner of a new hardy race of Plums. American origin.

Damson. See Shropshire Damson.

De Soto. Hardy. Red. September. Tree a good grower and very hardy. Fruit only medium size, round-oblong. Skin thick. Color red, with slight purplish bloom. Flesh orange color, firm, juicy. Quality good. Pit clings. Ripens late. An American Plum. Productiveness is increased by planting a number of them near together, or grouping them with other kinds in a cluster. Only desirable for extremely cold secticns. Origin, Wisconstn.
Empire. Dark purple. Early September. Fruit large, oval. Color dark purple. Quality good. Tree hardy, productive and vigorous, fruit ripening about September 5 to 10. This is a good orchard Plum. Originated in Cort. land county, New York.

Fellemburg. French or Italian Prune. Dark, purple. Late August. An excellent late variety. Fruit medium size, oval, tapering at ends. Color dark purple, with dark blue bloom. Flesh greenish yellow, juicy, sweet, of good quality. Freestone. Valuable for drying. Tree a free grower, and very productive. Named Italian Prune by some.

Forest Garden. Hardy. Dark. Septem. ber. Well adapted for the north, being very hardy. Fruit is not large, nearly round. Color orange-yellow, overlaid and dotted with red, almost a purplish red, when fully ripe. Flesh orange color, moderately firm, fibrous, juicy, good. Pit clings. Productiveness is increased by planting a number of them near together, or grouping them with other kinds in a cluster. Should only be planted in extremely cold sections. Origin, Illinois.

German Prune. Purple. September. Fruit large, long-oval, curved or swollen on one side, with a long, tapering neck. Skin purple, with a thick blue bloom, Flesh green, firm, sweet, pleasant, not rich. Pit free. Valuable for drying, an industry that is increasing in importance. Much used for preserving also, so that the market demand is good, making a good price for the fruit.

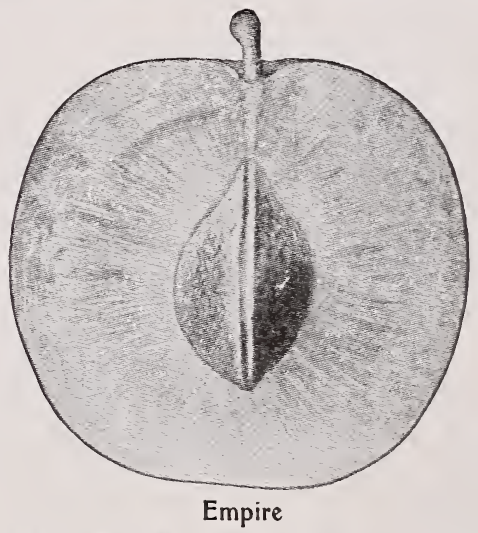

Giant Prune. Dark purple. September, following Girman Prune. Is one of the new productions of Luther Burbank, of California, and is one of the very best Prunes for general cultivation. We have fruited it here, and find it one of the finest Prunes in our orchards. It is a good grower, and a strong, regular fruiter. The fruit is very large, oval, not pointed. Color dark purple. Flesh dark yellow, sweet and good. Freestone. Highly recommended as a market fruit. Dries well. Ripe a few days later than German Prune. Origin, Califcrnia. 
Grand Duke. Purple. Late September. Bulletin No. 131, sent out by the Cornell University Experiment Station, Ithaca, New York, says :

Originated and sent out in England by $\mathrm{Mr}$. Thomas Rivers who has furnished to the world three of the largest and most beautiful late Plums of recent introduction. A very large purple Plum, so attractive in its appearance as to be a fine market sort, and apparently well adapted for general cultivation over a wide area.

The tree is not a strong grower, and does not come into bearing early, a fact that is generally to be regretted.

Guii. Dark. First to midadle of September. Fruit very large, deep bluish purple, covered with thick bloom. Flesh yellowish green, sweet and pleasant. Tree a great and very young bearer, hardy and a strong, rapid grower ; generally regarded as of great value for market by the Plum growers along the Hudson river. Origin, Lansingburg, N. Y.

Hudson River Purple Egg. Purple. Middle of September. Highly esteemed by growers along the Hudson river. Described as one of the richest and finest flavored Plums we have. Stone free. Fruit good size, resembles the German Prune, but a little larger, with a nice bloom. Good bearer. Tree bears young.

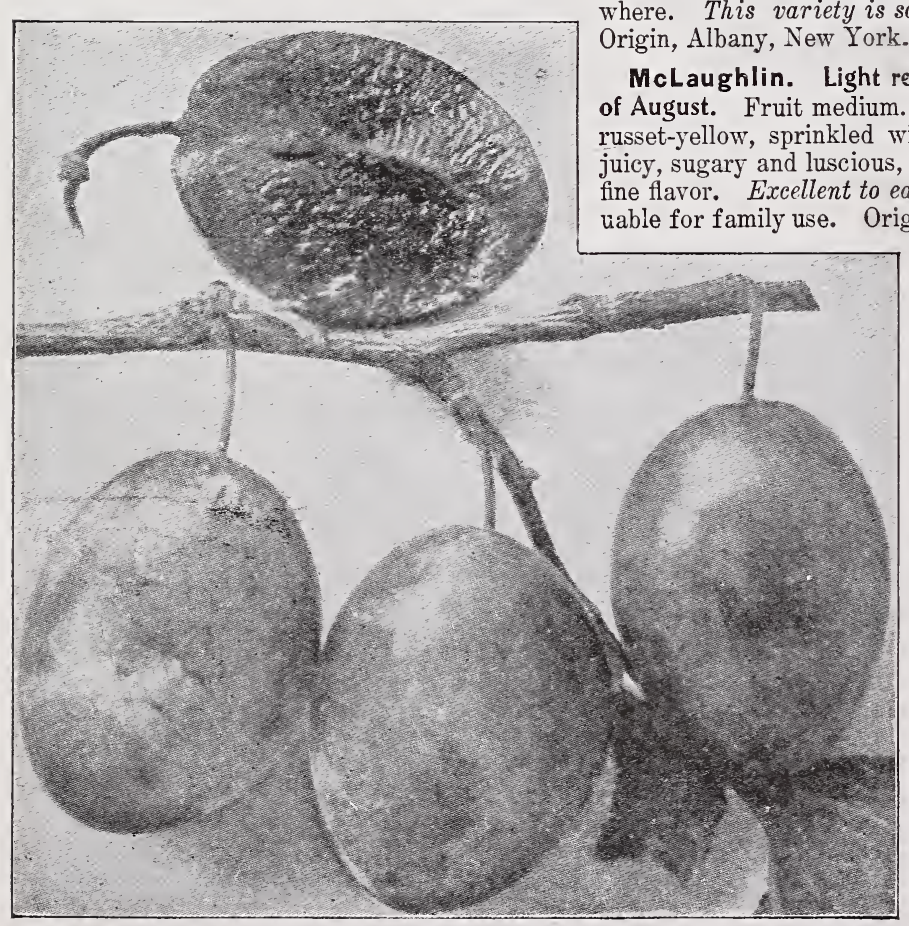

German rrune.
Imperial Gage. Green and yellow. Last of August. One of the most productive. Fruit rather large, oval. Surface green, slightly tinged yellow, with marbled green stripes Flesh greenish, juicy, melting, rich, sometimes adhering, but usually free from the stone. A strong, vigorous grower, very productive.

Italian Prune. See Fellemburg.

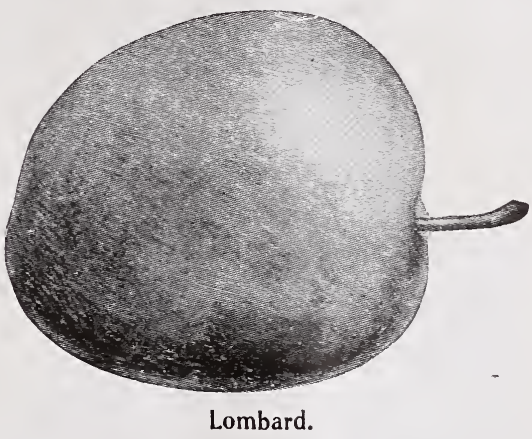

Lombard. Violet-red. Last half of August. Fruit medium size, round, oval, slightly flat. tened at ends. Skin violet-red. Flesh deep yellow, juicy and pleasant; good quality. Tree a great bearer and hardy. Valuable most any. where. This variety is sold very extensively Origin, Albany, New York.

McLaughlin. Light red and yellow. Last of August. Fruit medium. Skin thin, tender -yellow, sprinkled with thin red. Flesh

Monarch. Dark. September. Fruic dark purplish blue, covered with a thin bloom; nearly spherical ; large, being about six inches in circumference. Flesh pale greenish yellow, nartly free from stone, juicy, and with a pleasant flavor. Trees come into bearing very young, and bea1 abundantly.

Monroe. Light Early September. Fruit medium size, roundish. Color greenish yellow. Flesh firm, rich and sweet. Tree vigorous and healthy. Bears abundantly. 
Moore's Arctic. Hardy. Dark. Septem. ber and October. Fruit medium size or below. Skin purplish black, with a thin, blue bloom. Flesh greenish yellow, juicy, sweet and of pleasant flavor. 'Tree healthy, vigorous, an abundant and a young bearer. Origin, Maine. Mr. Charles Downing speaks of it as follows:

A new, hardy Plum, which originated on the highlands of Aroostook county, Me., where, unprotected and expnsed to Arctic cold, it has for many years borne enormous crops, and is said to be the hardiest Plum known.

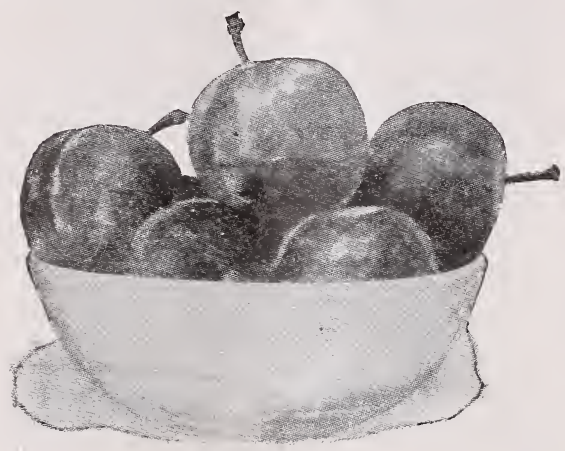

Moore's Arctic.

Niagara. Purple. September. Fruit is of extra large size and first rate flavor. Color dark purple. Good bearer; not liable to rot. Freestone. E. Moody \& Son, of Lockport, N. Y., say it is one of the most profitable var ieties to grow, and ranks very high.

Prince Englebert. Dark purple. End of August. Fruit very large and long. Color deep bluish purple with a dense bloom. Flesh juicy, melting. Quality rich and excellent. Freestone. Tree very vigorous. Desirable and decidedly profitable as a market Plum.

Prince's Yellow Gage. Yellow. Early August. Fruit medium size, oval, slightly broadest at the base. Surface golcen yellow, slightly clouded, bloom white, copious. Flesh deep yellow, rich, sugary, melting, sometimes rather जry. Origin, Flushing, L. I.

Pearl Prune. Color light. Procured from Luther Burbank, who describes it in the following language:

A seedling of the well-known French Prune, which it surpasses considerably in size of fruit, which is handsome, flattened, ovoid in form; white, semitransparent, with a heavy white bloom. In honeyed sweetness, combined with a peculiarly attractive fragrance and flavor, it surely excels all other Prunes or Plums. The fruit, when cured, produces one of the most

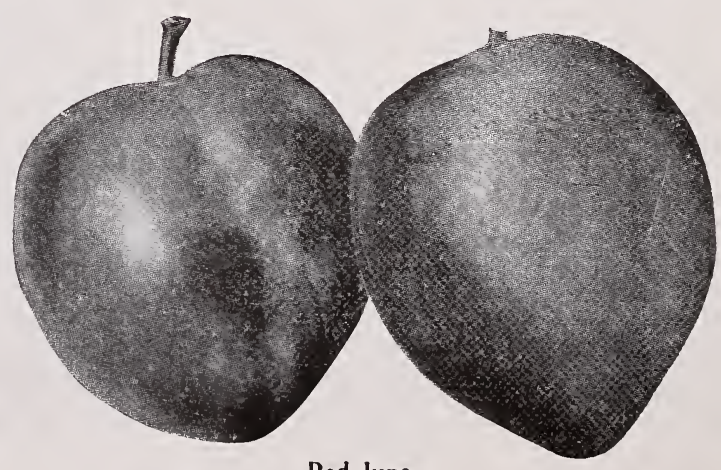

Red June. exquisitely delicious Prunes in existence, but requires care in handling, and will not cure well in the open air. Specially recommended for market and home use. Egg.

Purple Egg. See Hudson River Purple

Prunes. See Fellemburg Prune, German Prune, Giant Prune, Italian Prune, Pearl Prune, and Tennant Prune.

Quackenboss. Dark purple. Late Sep. tember. A popular Hudson river variety. Fruit large, oblong, oval. Color deep purple. Flesh greenish yellow, juicy and sweet, slightly coarse in texture, with a sprightly flavor. Partly freestone. Origin, Albany, N. Y.

Reine Claude de Bavay. Light. Sep. tember. Fruit large, round oval shape. Color greenish yellow, spotted with red, with small violet colored veins. Flesh juicy, melting and sugary, with a rich, excellent flaver. Tree vigorous and remarkably productive of fine fruit.

Red June. Japanese. Deep red. Season very early. Fruit medium to large size, long conical. Color deep vermilion red, with handsome bloom; very showy. Flesh light lemon yellow, slightly subacid, of good and pleasant quality. Small pit and half cling. Tree vigorous, hardy, upright, spreading and handsome.

Satsuma. Japanese. Red. Midseason. Fruit medium to large, broadly conical, with a blunt point; suture very deep. Color very dark red, with greenish dots and blue bloom. Flesh blood red, rather coarse and acid, fair to good in quality ; clings to the pit. Midseason. Tree very productive.

Shiro. Japanese family. Clear light yellow. August and September. Luther Burbank, its originator, describes the fruit as

"Medium to large size. Color clear light vel. low with an almost imperceptible thin white bloom and so transparent that the pit can be seen through the flesh. which is juicy, rich, pleasant subacid, clingstone. The fruit will keep in good condition at least a month."

Shiro is described as being a strong growing tree and very productive. $\bigcap_{i}$ igin California. 
Shipper's Pride. Red. First to Middle of September. An unusually thrifty grower. Very productive. Fruit of large size and nearly round. Color light red, white bloom. Flesh red, firm, sweet, juicy. Quality fine, juicy and sweet. Excellent for canning. An unusually good shipper, being a long keeper. A splendid market plum. Originated near Lake Ontario, N. Y.

Smith's Orleans. Dark. Last of August. Fruit very large, oval, slightly wider at stem. Skin reddish purple, becoming very dark; bloom deep blue. Flesh deep yellow, slightly firm, juicy, rich. Productive in nearly all soils. Origin, Long Island, N. Y.

Stanton. Purple. Early October. Fruit roundish oval, medium to large size. Color deep bluish purple, covered with rich bloom. Flesh yellow, firm, rich and sugary, and parts freely from the stone. A chance seedling, originated in Albany county, N. Y.

Shropshire Damson. Purple. October. Fruit is small size, roundish, but larger than the old fashioned Damson. Color purple. Flesh amber colored, juicy, quality good. Tree vigorous, hardy, productive. Of great merit for preserving. English origin.

Tennant Prune. Dark purple. Middle to last of August. Fruit large. Color dark purple, overspread with heavy blue bloom. Flesh sugary, juicy and delicious, and perfectly free from the stone. The originator makes the statement that "the original tree has been known to bear 1,000 pounds of Prunes in one season." The tree is very hardy and vigorous. Ripens its fruit about one month earlier than other varieties of Prunes. Possesses great bearing qualities, making it valuable for market purposes: Originated in the state of Washington.

True Sweet Botan. See Abundance.

Washington. Yellow. Late August. Fruit large, roundish oval. Color yellow, with slight crimson bloom. Flesh sweet, delicious.

Weaver. Hardy. Dark red. Midseason. Dr. Ennis, of Clinton, Iowa, kindly furnishes the following description:

It is one of our ordinary wild Plums, of fine size, good flavored and wonderfully productive. The tree is very hardy, never injuring even in our severest winters.

Size medium, oblong, flattened. Color dark red, with purple bloom. Pit free. A good canning Plum. Where good cultivated Plums can be raised, this Plum may not have much value, but in the west and extreme north it is valuable. Productiveness is increased by planting a number of them near together or grouping them with other kinds in a cluster. Origin, Iowa.
Wickson. Japanese. Deep red. Late September. Fruit is very large size, often 8 to 9 inches around. Color deep maroon-red, covered with a light bloom. Flesh firm, and a long keeper; has an aromatic, almond like flavor; meat is a deep, dull yellow ; pit small. Fruit in shape is oblong, pointed. The Cornell University Experiment station reports that the tree has been perfectly hardy with them. Tres is a good and upright, compact grower, something of a vase shape ; fruit evenly distributed over the tree, and is very productive. An enormous bearer. "Wickson bears the largest Plums we have ever seen; 22 degrees below zero did not even brown the pith of the late shoots."-Rural New Yorker.

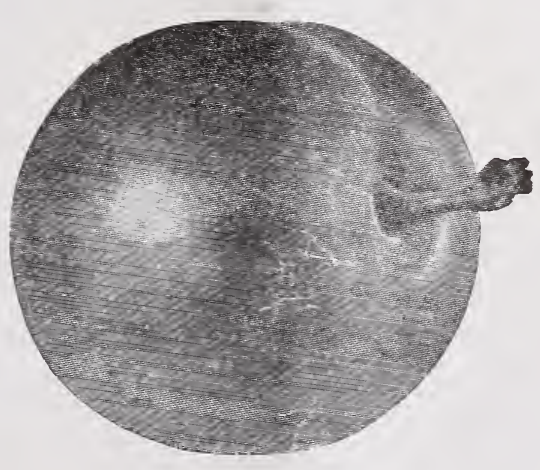

Wickson.

Wild Goose. Light Red. Middle August. Fruit medium size, roundish. Skin thin, shiny, bright light red. Flesh yellow, pulpy, very sweet, juicy when fully ripe. Pit clings. It is advised to pick the fruits 3 or 4 days before ripening, and ripen in the house; if left to hang on the tree too long they become too soft for shipping. The tree is a poor self fertilizer and should have other Plum trees, with an abundance of pollen, planted near. Origin, Tennessee.

Wolf. Yellow. Season early. Fruit is medium size, round. Skin is thick yellow, mottled red. Flesh yellow, firm, fibrous, good. Freestone. Tree is a strong grower and very prolific. Valuable for market and for home use. Origin, Iowa.

Yellow Egg. Yellow. Late August. Fruit very large and beautiful, oval, narrow at ends. Skin light yellow, with thin white bloom. Flesh firm, coarse, acid, becoming sweet by ripening. Excellent for cooking. Vigorous and productive.

Yellow Japan. See Chabot. 


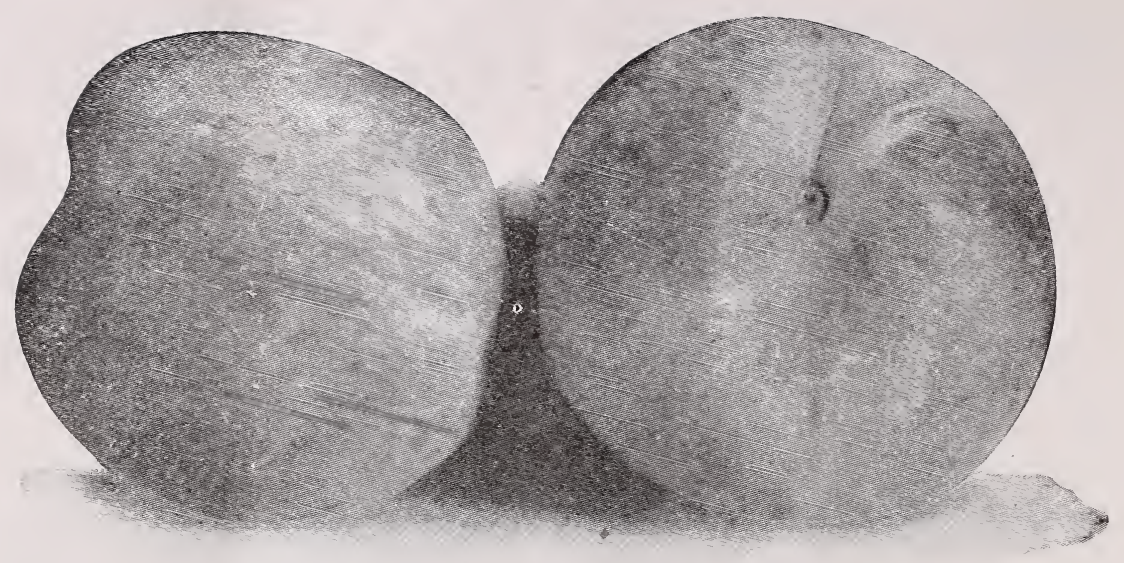

Triumph. (See page 25.)

\section{SELECT PEACHES.}

N planting Peaches, cut back the trees severely. This is of the highest importance. The trunk should be recuced about one-third, and the side branches back to one bud. This lessens the demand upon the roots, and enables the remaining buds to push more vigorously.

PEACH FRUIT is produced on wood of the last season's growth, bence the necessity for keeping up a good supply of vigorous annual shoots all over the tree. Keep the ground clean and mellow around the trees. Keep the heads low-the trunk ought not to exceed 3 feet in height. Every spring prune and shorten the shoots of the previous year's growth; thus keeping the head round, full, and well furnished with bearing wood. Cut weak shoots back about onehalf, strong ones one-third; but see that you have a sufficient supply of fruit-buds.

Alexander. Deep red on greenish white. Flesh white. Season late July. Fruit about medium size. Flesh whitish, sometimes stained next the skin; half melting, juicy and sweet. Stone small, and adheres but slightly. Tree healthy and vigorous, proliflc, bears young. Introduced from Illinois.

Beer's Smock. Orange-red on yellow. Flesh yellow. Season first part of October. Fruit large, oval, well calculated for distant market shipment. Flesh bright yellow, red at stone, moderately juicy, rich. Freestone. Valuable for drying purposes and for canning. Tree vigorous. One of the most valuable late Peaches. A seedling of the old Smock Free. Origin, New Jersey.

Carman. Red. Flesh Yellow. Early. The Carman (named after the late editor of the Rural New Yorker) is described by that valuable paper as follows:

"Promises to stand at the hoad for a general long distance, profitable market variety. One of the hardiest in bud. The early bearing habit of the Carman is remarkable. In quality ranking absolutely superior to anything ri pening at the same season. In its shipping qualities-in freedom from rot-this excellent Peach is unsurpassed.'

The originator reported, "six regular crops from the original tree in as many years." Season very eariy; size large, and just about half the Peach is striped and mottled with crimson, the rest being a light buff color.
Champion. White, red cheek. Flesh White. Season August. Fruit grows very large, many specimens measuring 10 inches in circumference. Color a creamy white, with red cheek. Flesh white; flavor delicious, sweet, rich and juicy. Freestone. Tree very hardy and productive. Its record covers with. standing a temperature of 18 degrees below zero, and of bearing a heavy crop in 1890, when there was an almost total frilure of the Peach crop on account of the extreme cold. A good shipper. Comes from Illinois.

Connecticut. Deep yellow, red cheek. Flesh yellow. Late August and first part of September. Fruit is large, round, highly flavored. Hardy.

Crawford Early. Red. Flesh Yellow. Season early September. Fruit very large, handsome. Color a beautiful, showy yellow and red cheek. Flesh deep yellow, very juicy and rich, and of splendid flavor. A magnificent large yellow Peach of splendid quality. A variety most desirable and well deserving of its great popularity, for its size of fruit, beauty of color, and productiveness make it one of the most popular orchard and "home use" $\mathrm{va}^{-}$ rieties. A perfect freestone. Tree is very productive. Origin, New Jersey.

Crawford Late. Red. Flesh yellow. Sea. son late September. Fruit very large, round- 
ish; surface yellow, with a broad dark red cheek. Flesh deep yellow, very juicy, rich, of good flavor. Tree productive. What is said of the Early Crawford can be repeated of this variety. In color, size, quality, and for general all-around good points, our two Crawfords are fine fellows, and will please. For home use or market, they can be depended upon. Origin, New Jersey.

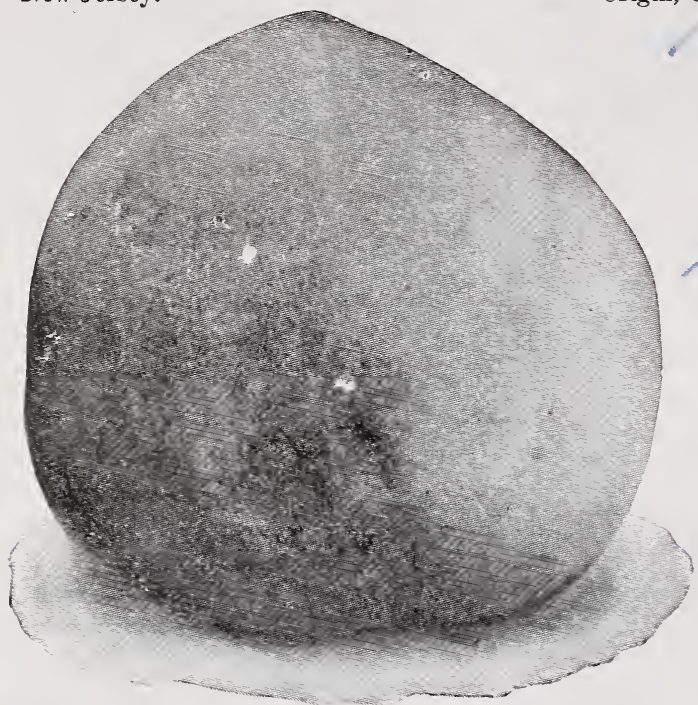

low, covered with a bright crimson blush; very handsome. Flesh pale yellow, tender, juicy, good quality. Entirely freestone. Elberta fruit can be gathered before it is ripe, and it will ripen up without rotting. A remarkably profitable market sort. Is being heavily planted for orchards. Bears transportation well. Tree vigorous, hardy, and comes into fruiting young. Origin, Georgia.

Early Canada. White and red, Flesh white. Season July. Fruit of good size, firm quality, and handsome appearance. Its earliness, and the fact that the fruit cleares from the stone, almost as thoroughly as later varieties, make an unusual demand for this Peach. Origin, Jordan, Canada.

Fitzgerald. Yellow and red. Flesh yellow. Season Middle September. Origin, Oakville, Ontario, Canada, outside the "Canadian Peach Belt," in a cold section, where Peach growing as a business was never made profitable with other varieties, but where Fitzgerald proves suitably hardy. Fitzgerald commences to bear fruit young. Fruit very large size, larger thian Early Crawford; classed among the best for good quality of fruit. In bearing qualities, Fitzgerald ranks with the heaviest croppers. One strong point is the smallness of the pit. Messrs. S. \& W. Collinson, Toronto, Canada,

Fitzgerald.

Crosby. Yellow, splashed red. Flesh yel. low. Season middle of September. It unquestionably is one of the hardiest Peaches of good quality. It has borne immense crops where other kinds in the same orchard were killed. The fruit is full medium size, roundish in form, slightly flattened; with a distinct seam on the blossom end. Color orange-yellow, splashed and striped with carmine. Flesh is yellow, with red at the pit, firm, moderately juicy, and of good quality. Stone very small. Tree an enormous bearer. Has been tested for ten years in the bleakest parts of New England and has proved itself to be first class in every way. Originated in Billerica, Mass.

Early Rivers. Creamy white, pink shaded. Flesh light. Season late July. Fruit large size, roundish. Color creamy white, shaded with pink. Flesh light, soft, melting, rich. English origin.

Early York. Red. Flesh light. Season middle to last of Aúgust. Fruit large, roundish. Skin nearly white in the shade, with red dots and with a deep red cheek to the sun. Flesh nearly white, fine-grained, very juicy, excellent flavor. Called "Honest John" by some.

Elberta. - Red. Flesh yellow. Season latter part of September and early October. Fruit above average in size, round. Skin golden yel- who are among the largest and most experienced growers, say of Fitzgerald:

"I consider the Fitzgerald crops at least 25 per cent. heavier than these other sorts. Owing to the immense size of the Peach, it requires but half as many to fill the basket as it does of the other varieties; therefore, it is most profitable in that respect. It has brought me prices three times as high as the ordinary sorts. The rich flavor of the Peach and its handsome coloring make it a sure seller.

"Even this year, when there was such a glut on the market, when common kinds were bringing 20 cents a basket, I was able to get 50 and 60 cents for $m$ J Fitzgeralds.

"During the Peach season I shipped, in two week's time, about ten carloads of peaches, from which you know I am no novice in the miatter, and my experience in this line of fruit leads me to say that Fitzgerald stands at the very head of the list as a profitable variety.'

Foster. Yellow, red cheeked. Flesh yellow. Season early to middle September. Resembles Early Crawford in general character and appearance, and is said to be a seedling of that popular variety. Ripens with Early Crawford. Originated in Massachusetts.

Greensboro. Red. Flesh white. Season extremely early. Fruit medium to large size. Color red, shaded with yellow. Flesh white, juicy, good. Mr. J. Van Lindley, of North Carolina, states:

"While I was shipping Alexander, not onethird of which were ripe. I visited the original Greensboro tree; the tree was loaded with fruit color $\in$ d beautifully, uniformly large, av- 
eraging more than double the size of Alexander. I was told that they had been ripening more than a week, and about every Peach on the tree was then ripe evough to ship, most of them getting soft."

Garfield. Red. Flesh yellow. Season late September. Fruit fully medium size. Color deep orange-red, becoming red on the exposed side. Flesh yellow, very rich and juicy. Origin, Cayuga county, N. Y.

Globe. Yellow, red cheek. Flesh yellow. Season latter part of September. Fruit globular and of very large size, frequently measuring 12 to 14 inches in circumference. Flesh firm, juicy, luscious, and a free stone. Tree a rapid grower and an enormous bearer. Good shipper. Originated in Pennsylvania.

Hill's Chili. Yellow, shaded red. Flesh yellow. Season late September. Fruit full medium size. Flesh yellow, rather dry. Tree hardy, productive, a valuable market sort. Origin, Monroe county, N. Y.

Hynes' Surprise. Yellow and red. Flesh whi'ish Season late July. A perfect freestone. Flesh of high flavor, melting, juicy. Fruit medium size, and valuable on account of its showy appearance, it being a perfect free stone and its ripening so early. Color dark red on the sunny side shading to yellow.

Honest John. See Early York.
Heath Cling. Yellowish white, red cheek. Flesh pale. Season very late. Fruit very large when season admits of it iully maturing; in the north it matures fully in the warmest seasons only. Surface quite downy, pale yellowish white, sometimes faintly tinted with red next the sun. Flesh pale, exceedingly juicy, melting, sweet rich flavor. A clingstone. Season very late, about middle autumn, and the fruit may be kept nearly until winter. Tree quite hardy and vigorous. Origin, Maryland. This is the only real clingstone that we grow.

Longhurst. Yellow, red cheek. Flesh yellow. Season late September. The fruit resembles Early Crawford, being of excellent flavor, size and quality. This is a new Peach, originated in Ontario, Canada, and, as might be supposed from its birthplace, is hardy, bearing annually large crops. The season of ripening and the hardiness of the tree make it valuable in colder climates.

Michigan Chili. Yellow and dark red. Flesh yellow. Season late September. Fruit large. Flesh yellow, juicy. Tree vigorous, hardy grower. A valuable orchard variety. Very productive.

Morris White. Creamy white. Flesh white. Season middle of September. Fruit rather large, roundish; surface rather downy, of pale creamy white, rarely tinged with purple to the sun. Flesh slightly firm, wholly

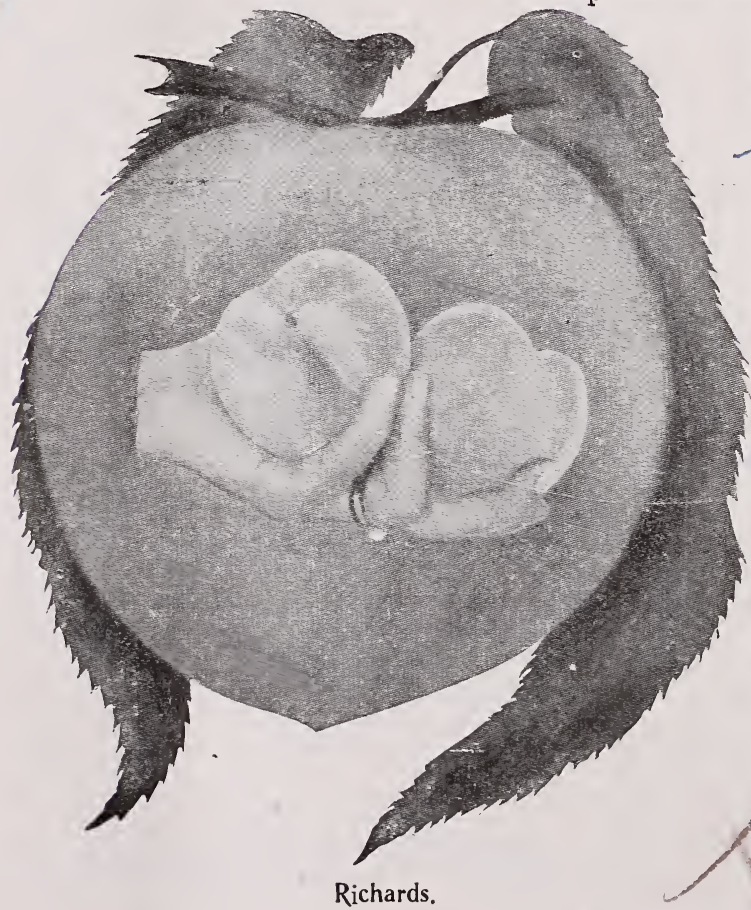
white, very free from the stone, melting, juicy, of a good, rich flavor. It is at its best in the middle states, though popular almost every where.

Mountain Rose. Nearly white, dark red cheek. Flesh white. Season medium early. Fruit large, roundish. Color whitish, covered with light and dark rich red. Flesh white, slightly stained at the stone, sweet, juicy. Separates freely from stone. Valuable sort for market. Origin, New Jersey.

Oldmixon Free. Red. Flesh light. Season middle of Septem. ber. Fruit large, roundish, slightly oval, one side swollen. Flesh light colored and deep red at the stone, tender, rich, excellent. Skin pale, yellowish white, marbled with red, and with a deep red cheek when fully exposed. Succeeds well in all localities.

Richards. Yellow, red cheek. Flesh light. Season middle of September. Received the first prize at the State Fair at Syra- 
cuse, N. Y., in 1895, for beautiful shape, color, quality and extreme size. In 1892 after thor. ough investigation, we purchased the original tree of the originator, and we now have com. plete control of the only stock of this variety. Since 1892 we have watched it in cultivation and in the orchard, and are now thoroughly convinced, after careful tests, that it properly ranks as one of the very best and most profitable market varieties. It bears young, and is a heavy cropper. Fruit is handsome and showy in color, and of most excellent quality. Bears shipment well. Tree hardy. Origin, central New York.

Richmond. Yellow, red cheek. Flesh yel. low. Season late September. Fruit medium to large size, round. Flesh yellow, pink at the stone, melting, very good. Origin, N. Y.

Salway. Yellow, crimson cheek. Flesh yellow. Season very late. Fruit large, roundish. Flesh deep yellow, red at pit, sweet, juicy. A freestone. A very late, valuable market sort.

Stump the World. Red. Flesh white. Season middle and last of September. Fruit large, slighily oblong, with red cheek. Flesh white, with an excellent flavor, and free from the stone. Vigorous and productive.

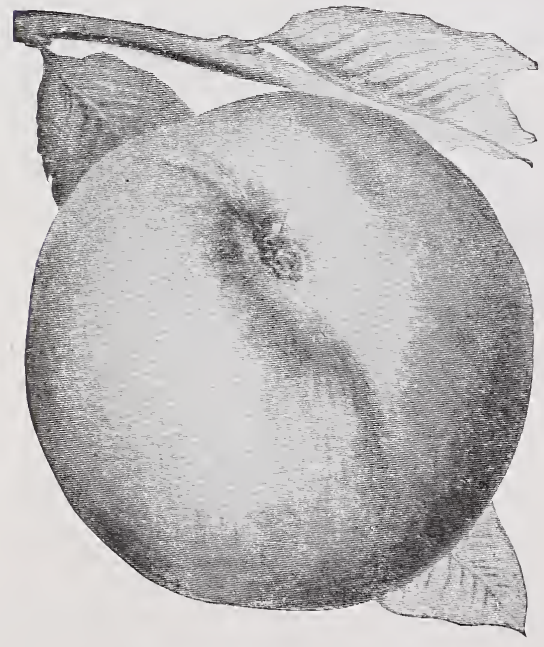

Sneed.

Sneed. Creamy white, red blush. Flesh white. Extremely early. Fruit medium size, oval. Color creamy white, with rich red blush on sunny side. Flesh greenish white, finegrained, juicy, sprightly, vinous, and adheres slightly to the stone; ripens evenly to the pit. Quality very good. This Peach has been cultivated in Tennessee and Mississippi for several years past, and has proved remarkably free from decay. It is considered one of the best of the early varieties, the crop being usually marketed when Alezander is well colored, its period of maturity at Augusta, Ga., for the past 4 years, being on an average of 6 to 8 days before Alexander. Tree of thrifty growth. and luxuriant foliage.

Steven's Rareripe. White, shaded red? Flesh white. Season late September and early October. Fruit large. Color white, shaded and mottled red. Flesh juicy, high quality. Reported as producing remarkably large crops in the vicinity of the Hudson River, New York state. Tree a heavy and regular bearer. Commences to ripen immediately after Late Crawford, and continues three or four weeks.

Schumaker. Greenish white and red. Flesh white. Season late July. Fruit large, round. Small pit, adheres slightly.

Triumph. Orange-yellow, red cheek. Flesh yellow. Season extremely early. Fruit large with a small pit; round; skin dark orangeyellow, nearly covered with rich red and showing dark crimson on the sunny side. Flesh bright yellow, and ripens up all at once, and evenly clear to the pit. When fully ripe separates quite readily from the stone, so that it may fairly be classed as a freestone; quality good. In the latitude of central Connecticut, Triumph ripens about Juiy 20 , and proportionately earlier farther south. The great value of this Peach for shipping purposes is its yellow color and attractive appearance, and its being a good keeper. Tree makes a very stronggrowth, blooms late, and is a sure and abundant bearer. Two-year-old trees have produced. over half a bushel of fruit per tree. Origin, Georgia. See cut, page 22.

Wager. Yellow. Flesh yellow. Season middle of September. Fruit fair size. Skin quite downy, of a light golden yellow when fully matured. Flesh bright yellow, good quality ; fairly firm, moderately juicy, sweet: separates readily from the stone. A little later than Crawford Early. Valuable for canning and drying. Tree is hardy. Origin, West Bloomfield, N. Y.

Wheatland. Golden yellow, crimson cheek. Flesh yellow. Ripens September, between Early and Late Crawford. Fruit large, roundish, of excellent quality. Flesh yellow, very firm, and bears shipment well. Tree productive. The originator reported 39 Peaches weighing 19 pounds. Origin, Wheatland, N. Y.

Willet. Yellow, with red cheek. Flesh yellow. Season middle to last of September. Fruit large ; handsome. Flesh highest quality, melting, juicy. Freestone. Tree hardy, productive, producing specimens even in size. 


\section{SELECT APRICOTS.}

THE season of ripening coming between the cherries and peaches, makes this fruit very desira.

ble and valuable. The dainty, showy appearance of Apricot fruit, its good quality that surely appeals to the taste of any who eat Apricot truit, and the fact that Apricot fruit is always ir good demand in the city markets, and at good high prices for fancy table use,are points so favorable that the planting of Apricot trees should have more attention from growers who raise fruit for market and growers who raise fruit for their family and themselves to eat.

Acme. Is recommended by a good authority who states: "The Acme is the largest and of choicest quality of any we have ever grown. It is also very beautiful in appearance. It seemed last season to have the power to resist the adverse conditions of the rainy spring beyond that of any other Apricot we were fruiting and made a fair crop where others failed.

Alexander. Of the Russian hardy race of Apricots. Color yellow, flecked with red, both skin and flesh. Season July 1. Fruit large, oblong. Tree hardy ; immense bearer. Flavor sweet, delicious. Recommended for extremely cold sections only.

Early Golden. Color wholly pale orange. Season middle of July. Fruit small (1 $1 \frac{1}{4}$ inches in diameter), roundish oval. Flesh orange-yellow, moderately juicy, rich and sweet. Free from the stone. Kernel sweet. Tree harciy, productive. Origin, Duchess county, New York.

Early Moorpark. Yellow, with red cheek. Season last of July. Fruit medium size. A freestone. Superior quality.

Harris. Bright yellow, with red cheek. Season late July. Fruit medium size. Flesh juicy. Freestone. Quality first-class. Tree a good grower, productive and hardy. Origin, New York state.

J. L. Budd. Of the Russian hardy race of Apricots. Color white, with red cheek. Season August. Fruit large. Flavor sweet, extra fine, with a sweet kernel, as finely flavored as an almond, and used for the same purpose. Tree hardy, strong grower and profuse bearer. Recommended for extremely cold sections only.

Large Early Montgamet. Pale yellow, with a tinge of red on sunny side. Season middle or latter part of July. Fruit large and round; quality the best, and a fine shipper. A very choice medium early sort; one of the very best in cultivation. Tree is a good, strong, healthy grower, and will stand a great deal of cold. Has borne heavy crops of fruit with us, and from what we have seen, consider it one of the very best Apricots in cultivation.

Moorpark. Orange, with deep orange-red cheek and dark dots. Season medium, or two

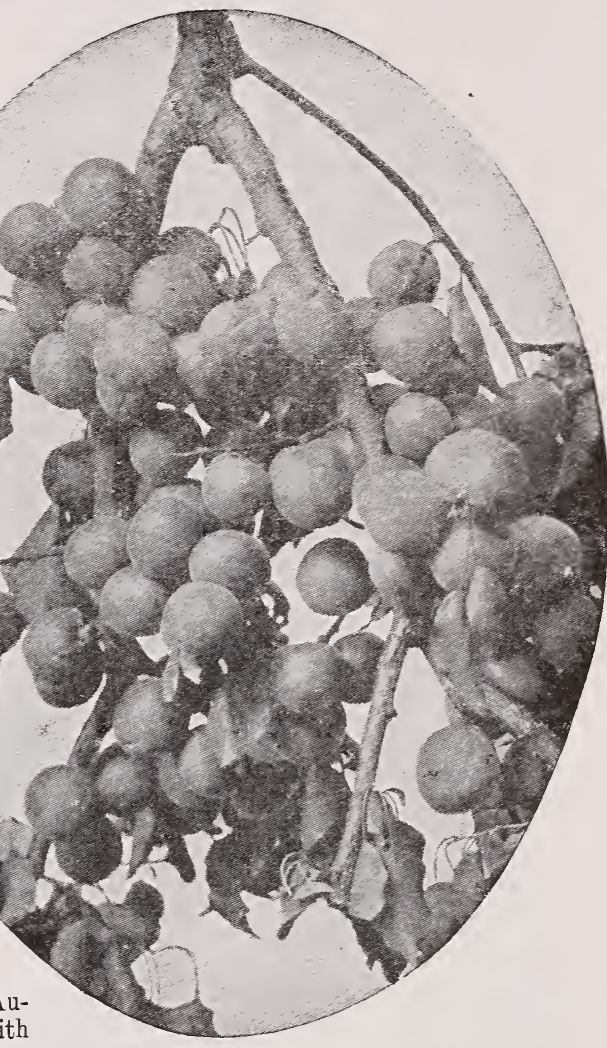

Large Early Montgamet.

weeks after midsummer. Fruit large (2 inches in diameter), nearly round. Flesh bright, yellowish orange, firm, quite juicy, with rich, high flavor. Freestone.

Peach. Skin yellow, with a brownish cheek. Season August. Fruit large, roundish. Flesh yellow, juicy, rich and highly flavored.

St. Ambrose. Yellow, shaded with dark orange. Ripens here the fore part of July. Fruit large, freestone, the best quality. This is an extra fine Apricot. Tree a good grower and very productive. Very hardy. In heavy fruit wi'h us, and from what we have seen, consider it one of the best in cultivation.

\section{SELECT NECTARINES.}

Early Violet. Medium size; yellowish green, with a purple cheek. Flesh pale green, melting; freestone. Season last of August.

Red Roman. Greenish yellow and red. Flesh greenish yellow : freestone. Season September. 


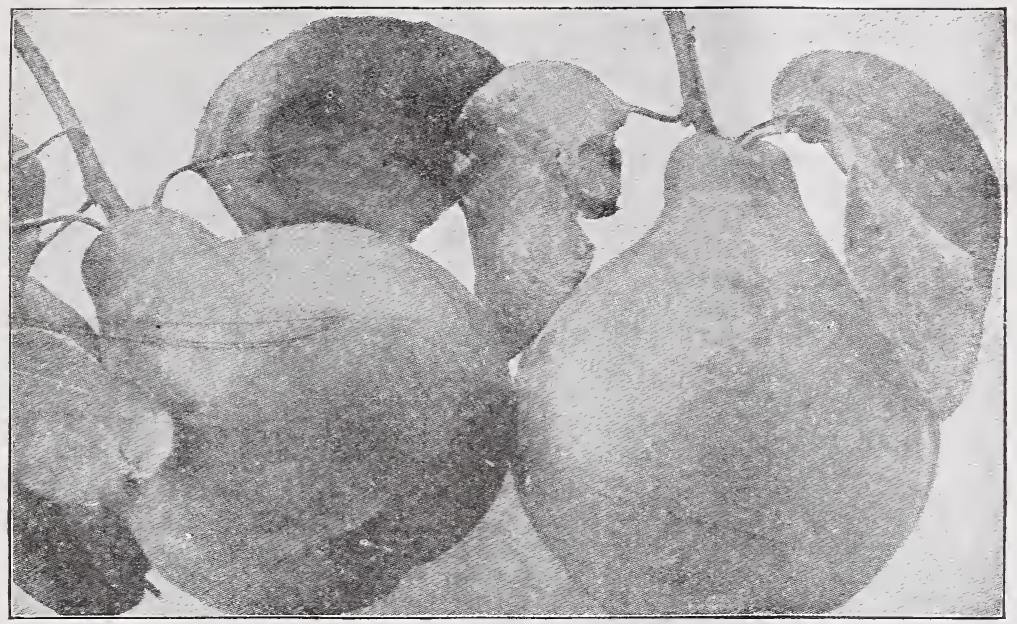

Rea's Mammoth Quince.

\section{SELECT QUINCES.}

FROM̃ Cornell Agricultural Experiment Station Bulletin, by Prof. L. H. Bailey: “The Quince crop is reliable, and not easily destroyed by capricious variations in weather. Trees are hardy and productive, easy to prune and spray, and diseases and insects, while rather numerous, are held in check with comparative ease, with the single exception of pear-blight.

"The lands should be retentive of moisture, but not wet and soggy. Good drainage is as essential to quince culture as it is to the growing of pears or other fruits. "Quince orchards should be given clean culture. The roots are usually shallow, and very shallow tillage is generally best. Probably best results will be obtained if trees are set 14 or 15 feet apart each way.

"The first fruits of consequence may be expected when the tree is 3 or 4 years planted, although the Quince does not arrive at full productiveness until it is 9 or 10, or more years old. An average crop for an orchard in full bearing is one bushel of first-class fruit to the tree, but this yield is exceeded in some years. Careful attention to handling and planting pays as well with the Quince as with other fruits. Pear-blight is the most serious disease of Quince trees, and there is no way of keeping it in check but to cut off and burn all affected parts.

"Three insects are mischievous in western New York Quince orchards: The borer (search for it twice a year), the codlin moth (put Paris green in the Bordeaux mixture), and the Quince curculio (jar it onto sheets, as you would the plum curculio)."

Bourgeat. Bright golden yellow. Ready for use from November through to March or April. Pronounced by a responsible grower, who has fruited it for 6 years, a profuse bearer, of large, handsome, showy, richly colored fruit, that actually keeps like Baldwin apples, in a good cellar, until spring. The core is very small. Will cook without hardness, like apples. Tree, robust grower. Origin, France.

Champion. Greenish yeliow. Season very late. Fruit large, distinctly pear form, furrowed about the top. Flesh tender. Tree bears abundantly while young. In some places it does not ripen well. A good keeper.

In a test at Cornell University Agricultural Experiment Station (New York), in 1892-93-94 -including Orange, Champion, Rea's and Meech-the Champion averaged the most productive, with Orange a close second.

Meech's Prolific. Pale, bright Orange, with a thin fuzz. Midseason. Fruit large, and in shape ranges from nearly apple shape to short pear shape. Very fragrant, good flavor. Bears when quite young. Productive. Supposed to have originated in Connecticut.

Missouri Mammoth. Attractive lemon yellow. Season middle autumn to middle winter Fruit large to very large, roundish, often largest at stem end. Surface nearly smooth. Flesh light yellow, moderately juicy, pleasant flavor, slightly astringent. Core rather small. Flesh cooks tender; of excellent quality.

Orange (Appile Quince). Bright pale orange. Ripens after mid-autumn, and keeps until February under good conditions. The surface only moderately fuzzy. Fruit variable in size and shape, but in the ideal or original form is distinctly flattened at both ends, like an apple. The most extensively cultivated of the old varieties.

Rea's Mammoth. Color rich orange, surface very smooth. Ripens early. Fruit large to very large, pear form. Flesh of excellent quality. Tree a very strong grower, distinguished by its short stature. Does best under high cultivation. We consider that for orchard purposes, as well as a garden tree, it 27 


\section{SELECT GRAPES.}

THE soil for the Grape should be dry and warm, thoroughly drained, deevly worked, and well manured, always bearing in mind that a sunny exposure is desirable-a slope to the south or east is the best. If a northern incline must be had, only the hardy, early ripening sorts should be planted.

\section{LIST OF LEADING GRAPES.}

Agawam. See Rogers' No. 15.

Brighton. Red. Season early. Its remarkable hardiness of vine, large and compact bunch, delicate skin, almost seedless pulp, and rich flavor, are qualities that make the

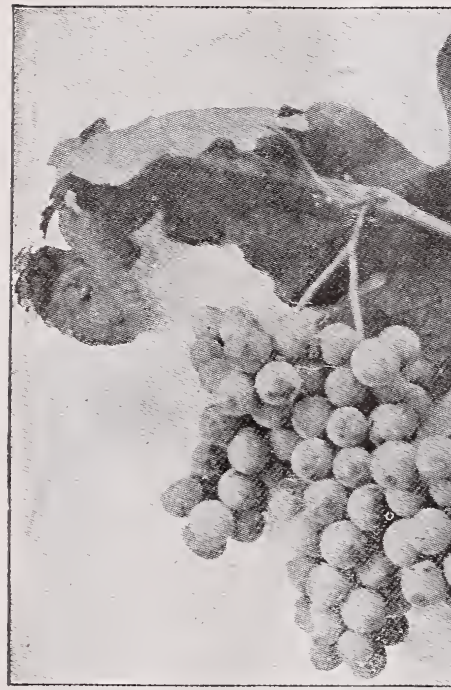

Brighton a most desirable sort. It has thick, large foliage, and is thus enabled to stand the heat of summer. Being a vigorous grower, it exhibits extreme hardiness, and is enabled to endure the winter in colder sections. Valuable both as a family Grape and for vineyard purposes. Berries above the medium size to large; color usually of a red when first ripe, and changing to a reddish purple if allowed to hang long on the vine, covered with a blue bloom. Fruit keeps well for an early Grape, either on or off the vine.

Campbell's Early. Black. From middle to last of August here. The vine is of strong, hardy, vigorous growth; the foliage thick, heavy and perfectly healthy, bears abundantly of large handsome clusters. The fruit ripens very early, and is of excellent quality ; is a remarkably good keeper and a good shipper. A bunch of the Campbell's Early sent to the United States Department of Agriculture, Washington, D. C., grown in 1896, weighed 19 ounces.
Berries of Campbell's Early are large, nearly round, often an inch or more in diameter; black, light purple bloom. Skin thin, very tenacious, handling and shipping admirably. Flavor rich, sweet, slightly vinous; pure, with no foxiness, coarseness or unpleasant acidity from the skin to the center. Flesh rather firm but tender and of equal consistency, parting easily from its few and small secds.

It has very remarkable keeping qualities. Has hung upon the vines, sound and perfect, for six weeks or more after ripening, with no tendency to shell off or fall from the stems. A few clusters were put in cold storage on September
Campbell's Early.

15 and taken out December 15, apparently as perfect as when stored, and seeming as though they might have been kept in good condition until spring. A good keeper and shipper.

The Rural New Yorker, of October 9, 1897, prints :

"A second vine of Campbell's Early Grape was received from the in troducer in the fall of 1895. It bore one bunch only, and this on a branch not over 6 inches above the soil. It was bagged when the berries were the size of the earliest peas, and the bag was not removed until September 21. The berries and bunch were absolutely perfect. Every berry was the size of every other berry, and all of them the size of the finest Concords. This is a most valua ble characteristic of this splendid Grape-uni. 
Eurmity of size and ripening. Its keeping qualities, as judged by this one trial, are also remarkable. The berries adhere as firmly to the stems as do those of the earlier season. In the writer's opinion, Campbell's Early, for the climate of The Rurai New Yorker grounds. is the nearest to perfection of any Grape grown there.

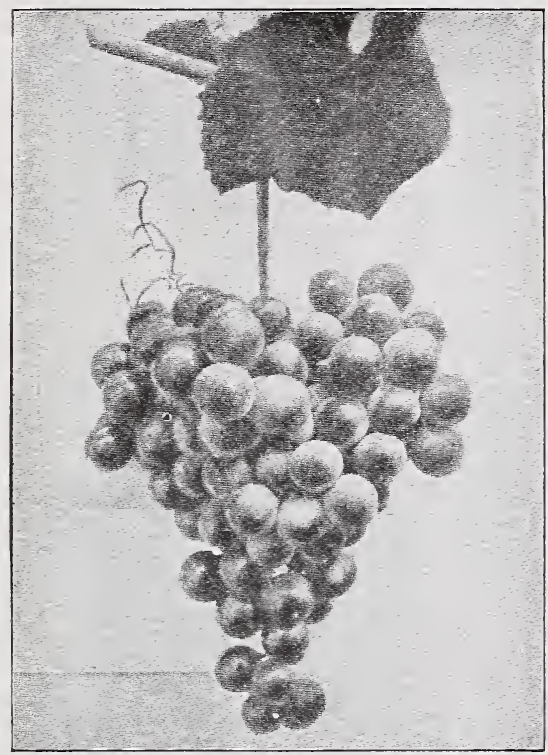

Brighton.

Concord. Black. Latter part of Septem. ber here. There is no variety as generally planted as this, extensive both as to the quantity of vines planted and the many localities where it is grown. The Concord succeeds well in most all parts of the country. The vine is a very vigorous grower, enormously productive, almost free from disease. Berries large, round, black, with a blue bloom. Bunch large, compact, shouldered. Skin tender. Flesh juicy, sweet. A profitable market sort. The fruit is too tender for shipping long distances.

Delaware. Red. Early Saptember. Its earliness, hardiness, and admirable sweetness have become well known to the public. Berries rather small. Skin of a beautiful, bright red color. Bunch medium in size, compact. Flesh is without hardness or acidity in its pulp, exceedingly sweet; juicy. Vine moderately vigorous and productive. Bears when young. Oftentimes injured by allowing it to overbear. Should have a strong, rich soil to do its best.

Eaton. Black. A little earlier than Concord. Berry large, round, black, blue bloom; juicy, tender. Bunch large, shouldered.

Empire State. White. Ripens early, al. most with Concord. Bunch large and shoul- dered. Berry medium to large, and roundish oval; of excellent quality. Color white, with light tinge of yellow, covered with thick white bloom. A good keeper. The vine is vigorous and hardy. Origin, Newburgh, N. Y.

Lindley. See Rogers No. 9.

Merrimac. See Rogers No. 19.

Moore's Diamond. White. Ripens about with Delaware. Described as a pure native; leaf resembles Concord; free from mildew. Bunch large, compact. Berry about the size of Concord. Color greenish white, with a yellow tinge when fully ripe. Flesh juicy, sweet to the center, free from foxiness, and almost without pulp. Quality very good. Vine vigorous and productive. While the skin is thin, it is sufficiently tough to stand handling and shipping well, Originated by Jacob Moore.

Moore's Early. Biack. About twenty days earlier than Concord. Fruit large and showy, and the variety is remarkable for size, beauty, productiveness, earliness and hardiness. It received first premium irom New England fairs and the Massachusetts Horticultural Society. Fruit black, very large and handsome, with a heavy bloom. Quality about the same as Concord, Vine exceedingly hardy. It has stood 20 degrees below zero, and has been exempt from mildew and disease. This hardy variety was raised by John B. Moore, of Concord, Mass., and was first fruited in 1872.

Niagara. White. Ripens with the Con. cord. The originator says :

This new white Grape originated in Lockport, N. Y., in 1868, and is a cross between the Concord and the Cassady ; first fruit in 1872; it

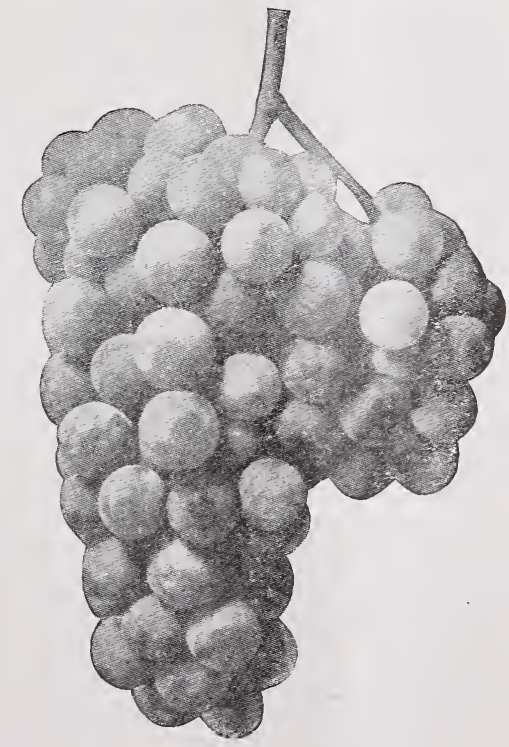


has since regularly borne large crops of fine fruit. The vine is a remarkably strong grower and very hardy. Tue leaves are thick and leathery, and dark, glnssy green. Bunches very large and uniform, and very compact. Berries as large as, or larger than, Concord. Skin thin but tough. which insures their shipping qualities. Quality good, very little pulp, melting and sweet to the centre.

Pocklington. White. Ripens with Concord. Vine very vigorous, hardy and productive. Bunch and berry of good size. Color a light lemon yellow. Flesh moderately tender, sweet, with a peculiar aromatic flavor. Orig. inated at Sandy Hill, N. Y.

Rogers' No. 15 (Agawam). Red. Ripens soon after Concord. Bunches large, generally loose. Berries large, round. Color dark red, or maroon. Flesh tender, juicy, vinous, with a high, peculiar flavor. Vine very vigorous, hardy and productive.

Rogers' No. 19 (Merrimac). Black. Early. Bunches rather large, short and broad, compact. Berries large, round; black, with a slight bloom. Flesh tender nearly to the center, juicy, sweet and high flavored.

Rogers' No. 4 (tyilder). Black. Ripens with the Concord. Buriches very large, shouldered, compact. Berry large, round, black, with a thin bloom. Flesh tender, sweet and sprightly. Quality best. Vine vigorous, hardy and productive. Succeeds in many localities.

Rogers' No. 9 (Lindley). Red. Rath. er early. Bunches medium size, rather long and compact. Berry medium size, round, reddish, sweet. Vine vigorous, productive.

Roger's No. 22 (Salem). Purple. Early when not overstocked, sometimes as early as Delaware. Bunches large, compact, shouldered. Berries large, round, purple. Skin thick and firm. Flesh sweet and tender, with a rich, aromatic flavor. Vine moderately vigorous, hardy, healthy. It is a splendid keeper and of good quality.

\section{Salem. See Rogers' No. 22.}

Vergennes. Red. Ripens with Concord. A fine red variety of delicious flavor. Very hardy and a strong grower. Clusters large. Berries large, meaty and tender. Origin, Vergennes, Vermont.

\section{Wilder. See Rogers' No. 4.}

Worden. Black. Ten days earlier than Concord, and superior to it in flavor. Bunches large, compact, handsome. Berries large, round, of excellent quality. Extra hardy. A seedling of Concord. Worden is a good Grape.

\section{SELECT ASPARAGUS. (For Fall or SPRING SETTING.)}

HOW to Grow for Family Use. No vegetable that can be produced so easily and cheaply. A bed of Asparagus of about 100 plants will give an abundant supply for an ordinary family. Asparagus is a very profitable vegetable to grow, as the crop is always salable at some figure, and probably the reason the market has $n_{2}$ ver been glutted is due to the fact that Asparagus culture

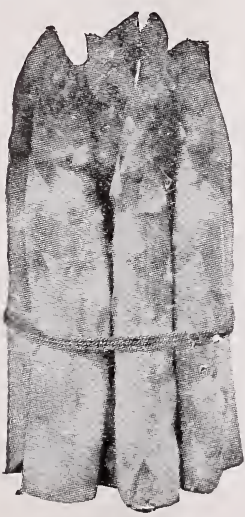
has been regarded by most people as extremely difficult. We know instances where it has paid $\$ 250$ to $\$ 400$ per acre clear.

To Plant for Market. Dig the soil deep, and incorporate in it a heavy coat of rotted manure or well decomposed compost. Plant the roots in rows 4 to 6 feet apart, and 3 feet between the roots, 8 or 10 inches deep, crowns up. Cover the bed in fall with manure ; fork it in in the spring. For Home Garden, set plants 1 foot apart in rows 18 inches wide, for hand hoeing, with same treatment as for market.

Cultivation and Cutting. After the plants are well started, give frequent and thorough cultivation, and draw a little earth into the furrows at each hoeing until they are filled. Early the next spring spade in a heavy dressing of manure, and 1 quart of salt to each square rod, and cultivate well until the plants begin to die down. The next season the bed may be cut over two or three times, but if this is done all the short shoots, no matter how small, should be cut, and after the final cutting give a good dressing of manure, ashes and salt. The next season the bed should give a full crop, and be annually dressed with manure, ashes and salt after the last cutting, and well but not deeply cultivated, until the plants occupy the whole space. In fall, as soon as tops are yellow, cut and burn them.

Insects. Young beds are sometimes attacked by black beetles, and if the grower does not have chickens running loose, a light dusting of air-slacked lime will end the beetle trouble. Poultry will be glad to do a good turn in the Asparagus bed for the harm they do in other places.

Conover's Colossal. A variety universally acknowledged to be an improvement on the older sorts, on account of its immense size, and being remarkably tender and high flavored. It is claimed that it can be cut one year sooner than other varieties. A profitable market sort. We recommend this very highly.

Donald's Elmira. New. Very large. 12 stalks averaged $4 \mathrm{lbs}$. Very tender and suc. culent. Profitable for market and desirable for family use. 


\section{SELECT CURRANTS.}

$\mathrm{T}_{\text {н }}$

HE Currant combines hardiness, ease of culture, great and uniform productiveness, pleasant flavor and early ripening, making one of the mosi valuable fruits. Gosd cultivation and pruning will more than triple the size of the fruit. Old bushes should have the old wocd cut out, and thrifty shoots left at regular distances. Old manure should be spader? in about the roots, and the soil kept clean, cultivated, and mellow. As the Currant starts and expands its leaves very early, this work should be performed as soon as the frost leaves the soil. Currants thrive best when they are somewhat shaded, consequently un excellent position for them is in the rows of young orchard trees. They can be successfully p]: inte? spring or fall.

Set 4 to 5 feet apart each way.

Cherry. Red. Ripe early Ju'p here. Fruit very large, nearly twice the size of the common Red Dutch; often $\frac{5}{8}$ of an inch in diameter; round; quite acid. Clusters moderately short. Growth of plant is tall, large and luxuriant.

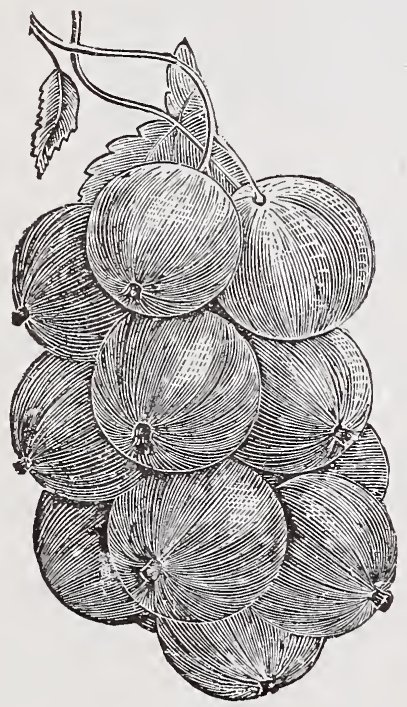

Fay's Prolific.

count of its fine quality and the extraordinary size of its bunches. The bunches are really enormous, being sometimes over 7 inches in length.

Lee's Prolific. Black. The fruit is of enormous size, wonderfully productive, and of agreeable flavor. Long stems of large berries. Very desirable for canning, and while a taste for this fruit often has to be acquired, it is always highly esteemed by those who are acustomed to use it. Plants are very hardy, and it is well suited to cold country sections

Moore's Ruby. Light red. Ripe early July here. A new, sweet, red Currant, recently introduced by Mr. Jacob Moore, the originator of the Moore's Diamond Grape. Prof. L. H. Bailey, of Cornell University, says of it:

Everything I have seen of the Moore's Ruby Currant pleases me, so far as its value for home use and dessert is concerned. It is a Currant of most excellent quality.

Newark. Red. Ripe early July here. We have for several years been growing and testing this new Currant. It is a great producer, of excellent quality, and will hang long on the bush; a strong and vigorous grower. We have the entire and only stock. Size above medium; subacid; bunch of good length. The fruit is borne in masses on the bush.

White Grape. White. Ripe early July here. Very large. Mild flavor. Excellent quality; good for table use. Very valuable.

Wilder. Red. Ripe middle July here. Fruit large, fine flavor. Very profitable for market, being a great yielder.

Fay's Prolific. Red. Ripe about July 10 to 15 here. A variety of great value on ac-

\section{SELECT RHUBARB.}

$\mathrm{R}^{\mathrm{H}}$

HUBARB, familiarly known as the Pie Plant or Wine Plant, is cultivated in gardens for its leaf stalks which are used for pies, tarts, canning, etc. The large size, fine texture and superior quality of the new varieties of Rhubarb over the old cultivated "Pie.Plant" cannot be conceived by those who have never grown it. It is very profitable to grow for market purposes, is always in demand, and commands good prices. It grows very rapidly; requires little cultivation.

Planting and Cultivating. Plants should be set $4 \mathrm{ft}$. apart each way, and the stalks will be fit for use the second season after planting. It is benefitted by a heavy coat of strong, rich manure.

Myatt's Linnæus. Early, very tender, and has a mild subacid flavor, not "stringy" or: tough. The plant is large, and for pies or other culinary purposes it is the housewif's's favirite.

Early Scarlet. As rather sma!l plant, but vesy early, tender and good
Eaton's Peach Flavored. Very early. Large, tender, delicate, rich peach flavor. For pie and sauce it is exsellent.

Victoria. Medium size, and quite a favorite in certain sections. It is early, tender and quite prociricive. 


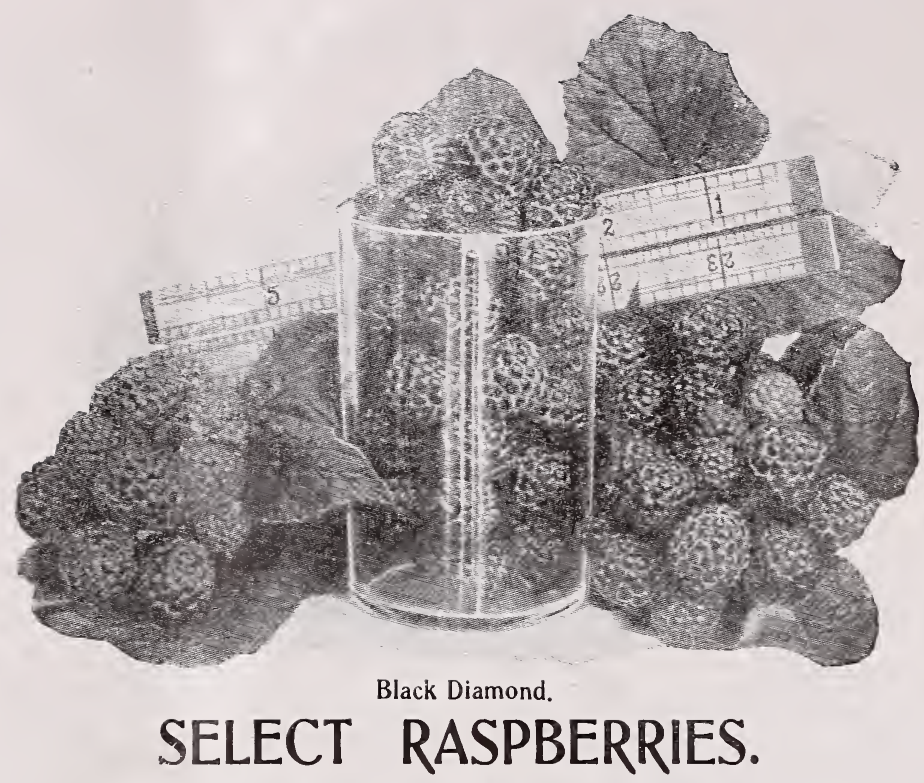

Set $3 \mathrm{ft}$. apart in row; have rows $7 \mathrm{ft}$. apart.

Black Diamond. Black. Time of ripening here, first half of July. The Black Diamond has shown itself to be the most profitable black Raspberry in the world. It is sweeter than anything else on the market, more pulpy, and contains fewer seeds; at the same time is firm and an A No. 1 shipper. It is a grand berry for drying, the dried berries being a jet black, and containing all the richness, fine flavor and sweetness of the fresh fruit.

Both the fresh and dried fruit command a high price on the market. We are offered 2 cents per pound more for our Black Diamond dried fruit than is being paid for choice fruit of other varieties. As our mature plants have yielded over 5,000 quarts per acre, this difference alone means $\$ 33$ per acre.

For health and vigor of plant, it cannot be surpassed. We have not seen one single stalk of Black Diamond affected with anthracnose. We never have to spray the Black Diamond, while other varieties, side by side with it, lose from an eighth to a quarter of their growing wood by fungus. One of the secrets of its great success is its ability to withstand the attacks of fungus.

We have a patch of Black Diamond on our place corering 1 1-10 acres of land, planted in the spring of 1895. This land has received no manure or other fertilization for 10 years. In 1896 the yield from this patch was over 1,500 quarts per acre; in 1897 the yield was 5,640 quarts for the piece, or over 5,000 quarts per acre. We estimate that 1,000 quarts per acre were lost by the very wet weather and heavy rains which we had when the berries were ripening. The rain spiasned the inud on the berries, and in many cases buried the lower branches in the ground. Most of the fruit from the lower branches was lost in this way, but still we gathered over 5,000 quarts per acre.

The tremendous yield, and the ease of picking the berries, made it possible to get our picking done for $1 \frac{1}{2}$ cents per quart, where others were paying 2 cents per quart.

A yield of 1,000 quarts of the Ohio per acre the first season is large, and 3,000 quarts for the second season is about the average, while we have a patch of Black Diamond planted in the spring of 1896 , containing six acres, from which we picked 9,000 quarts this year (1897).

From The Rural New Yorker, of February 19, 1898 :

* * Black Diamond Raspberry was received during the spring of 1896 . We find this blackcap among the most productive varieties ever tried at the Rural grounds. The berries are as large as those of the Gregg, the druplets being twice as those of the Cumberland. The quality is very good. It is among the earliest, and wonderfully productive, the one objection being that the berries have too much bloom. **

[The stems, on the end of which the berries grow, project from the druplets. The superiority of a variety having large druplets is at once apparent.]

From the New York Experiment Station, Geneva, N. Y., August 23, 1897:

The Black Diamond gave us its first fruit this season. It promises to be a valuable acquisition to our list of black Raspberries. Our notes on this variety are as follows: Fruit large size, good color and quality, firm and productive; plants strong and vigorous, worth $v$ of further testing. We have not figrured up the yilld of the different varieties so wo are nnable to give you the comparative productiveness of the klask Diamond. Very truiy, W. PADDCok. 
Columbian. Purplish red. July 12 to early August here. A seedling of the Cuthbert, grown near the Gregg blackcap Raspberry, and believed to be a cross between the two. Very hardy, enduring 28 degrees below zero without harm. Wonderfully prolific; 3,500 bushes produced, on an average, 5 quarts each, or 17,500 quarts. In 1896 , from 925 yielding bushes, or one-third of an acre, nearly 4,000 quarts were picked.

A fine evaporating berry, retaining color, form and flavor in a most remarkable degree, and selling for fully one-third more than blackcaps. In a thorough test in 1896 and 1897, it proved equally as good as Ohio, taking about three quarts to the pound.

An excellent shipper; very little crumbling or crushing either in handling or transportation, and finds a ready market. For canning purposes it holds its form, is of a beautiful color, is sweet and rich in flavor, and shrinks very little in canning.

Fruit very large, often an inch in diameter; shape somewhat conical; color dark red, bordering on purple; adheres firmly to the stem, and will dry on the bush if not picked; does not drop off, like other berries. Seed small, and deeply imbedded in a rich, juicy pulp, with a distinct flavor of its own, making it a most delicious table berry. Fruiting season is very uniform, extending from July 12 to early $\mathrm{Au}-$ gust. Generally lasts a week or 10 days longer than the Ohio, depending on the season, and maintaining its high quality to the last.

Its manner of fruiting is peculiar to itself, each berry growing upon a separate stem from 2 to 4 inches long, from which it is removed without crumbling. A very vigorous grower; canes 10 to 15 feet in length, and often over an inch in diameter, strong and woody ; color light green, changing to bright red in autumn. Foliage is very handsome and healthful, light green in color, retaining its health and hue until killed by autumn frosts. Roots are large and spreading, and penetrate the soil to a great depth ; thus Columbian is enabled to resist drought and wind storms.

Cuthbert. Red. Reports from all parts of the country uniformly rank the Cuthbert high. It is a tall, vigorous grower, very productive and hardy, and remains in fruit a long time. Berries large, conical, deep crimson, very firm, and of excellent quality.

Golden Queen. Golden yellow. The originator says :

"In flavor it rivals that high quality Raspberry, Brinkle's Orange. In color a rich, bright, creamy yellow, imparting to it a most appetizing effect, both in the crate and upon the table. In size it challenges the large Cuthbert. In vigor it fully equals its parent, the Cuthbert. In productiveness, it excells the prolific Cuthbert. In hardiness it has no superior.'

Possibly not practical to set a large field, but for home use and in a small way for market purposes, is desirable. Origin, Iowa.

Gregg. Black. First half of July here. Berries large, black, with a light bloom, comparatively free from seeds, and in quality good. The growth of the cane is very strong. As a market berry it is exceedingly valuable, the fruit being very firm, so as to ship in the best order. Origin, Indiana.

Johnson's Sweet. Black. First half of July here. Smaller than Gregg ; of same color. A good, strong grower ; healthy and hardy. Ripens with Tyler. Stands up well in picking and handling. Its merit is in its high quality and delicious sweetness of berry.

The Loudon. Red. July 10 to 15 here. The Loudon is pronounced, by E. S. Carman, of The Rural New Yorker, the best red Raspberry in existence. Its great value lies in its extreme hardiness. The Wisconsin and Minnesota State Horticultural Societies sent a committee to examine it on the grounds of the originator, and they reported it as

"The most promising red Raspberry that we have ever seen for productiveness, size, quality, flavor, firmness of fruit and hardiness, vigor and health of plant."

The canes are very strong, vigorous and hardy. Fruit bright red. With us, the Loudon averaged about the same size as the Cuthbert with ordinary culture. When well grown, the Cuthbert is perhaps the larger. The Loudon is perhaps the hardiest red berry grown, and will be largely planted, and is certain to become one of the leading market sorts.

Marlboro. Red. Early July here. One of the hardiest, earliest, largest, and best carrying berries. Splendid quality, handsome color, and a great bearer. In regard to its earliness, The Rural New Yorker acknowledges the receipt of ripe fruit on the 26th of June.

Ohio. Black. First half of july here. Very hardy, vigorous, and an enormous bearer. Flavor superior, and will bear shipping well and keep long. This is one of the most valuable blackcaps yet introduced. It takes high rank for drying purposes.

Shaffer's Colossal. Purple. This plant is a strong and large grower, is "ironclad" in hardiness, and yields an immense crop of dark, purplish red berries. The fruit is large, firm, and of a sprightly subacid flavor. This is a cap variety, and increases from the tips, like the blackcap.

Tyler. Black. Early July here. Ripens its entire crop within a very short period. Canes vigorous, strong and hardy, with foliage healthy; wonderfully productive. Fruit of good size, jet black, with but little bloom; firm, and if sweet, pleasant flavor. Valuable for market. 


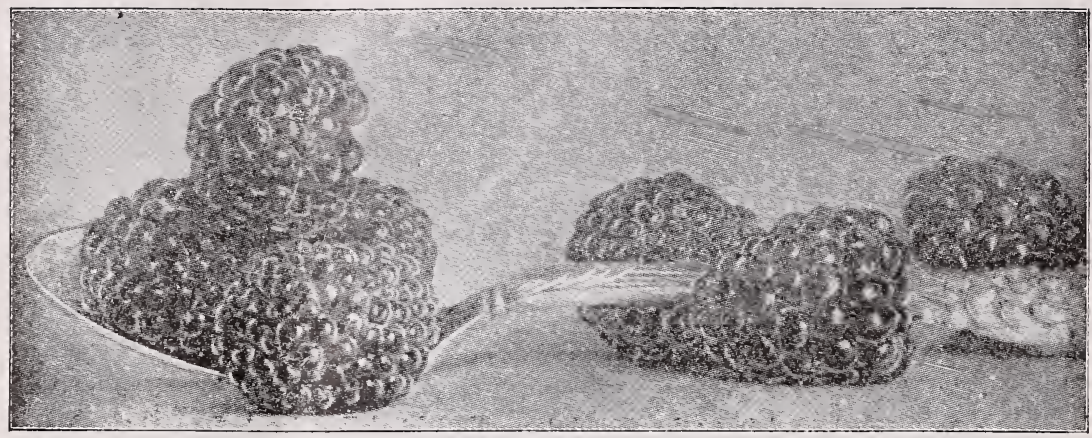

\section{SELECT BLACKBERRIES.}

Set $2 \mathrm{ft}$. apart in the row; have rows $6 \mathrm{ft}$. apart.

Erie. Black. Last half of August here, holds out late. A strong, healthy grower, free from diseases liable to attack the Blackberry. Productive as the Lawton, and without its failings. Very early; ripens even before the Wilson. Extra good quality. Fruit large, fine, berries jet-black in color, firm in texture, making it necessarily a popular sort for distant shipment, as well as for home market. Hardy, having withstood a temperature of 25 degrees below zero. Very desirable for our customers in northern climates. A chance seedling, which sprung up on the shores of Lake Erie, in northern Ohio.

Iceberg. White. Raised by Luther Burbank, the "Wizard of Horticulture." The following is Mr. Burbank's description :

One of the great grandparents of Iceberg was Lawton. The first generation of seedings, when crossed with Crystal White, was all black ; the second also, though varying much in other 1 espects ; but the third produced this wonderful plant, bearing the snowiest white berries ever seen.

Very little attention was paid to the long rows of cross-bred descendants, until one day this berry was discovered, among its black relatives, with the canes bending in various directions with their loads of delicious, snowy berries.

Clusters larger than those of Lawton ; berries, as near as can be judged, were at least as large, eariier, sweeter, more tender and melting throughout, though as firm as Lawton is when ripe.
Rašhbun. Black. Fruit jet-black, with a high polish, and sufficiently firm to handle and carry well. The whole crop is of a very uniform size. A comparison made in the season of 1896, taking the berries in each case just as they averaged, showed that a common strawberry quart box of Snyder counted 164 berries; the same package of Rathbun counted but 45 berries. A specimen measured was $1 \frac{3}{4}$ inches in length and $1 \frac{3}{8}$ inches in diameter. The fruit of the Rathbun, unlike most Blackberries, has no hard core, in fact, no core is perceived in eating it; all is soft, sweet and luscious, with a high flavor. The plant is a strong, erect grower, producing few suckers. As to its hardiness, it has stood 15 to 18 degrees below zero.

The Rathbun Blackberry is now (July) in full fruit, and we are very much pleased with it. Is midway between a Blackberry and a Dewberry in habit as also in earlines:. The berries are exceedingly large and glossy, jet black and of good quality. I certainly think that there is a future for it.-L. H. BAILEY, Professor of Horticulture, Cornell University, Ithaca, N. Y.

Snyder. Black. Ripens here first part of August. Enormously productive. Medium size. No hard, sour core. Half as many thorns as Lawton or Kittatinny, and they are nearly straight and short.

Wachusett. Black. We quote the following :

Fruit of medium size, oblong-oval, moderately firm; sweet and good, little acid. Good keeper. ships well, very hardy, and freer from stiff thorns than others.

\section{DEWBERRY.}

Lucretia. A trailing variety of the Blackberry. Ripens between the Raspberry and the Blackberry. A very desirable fruit. 


\section{SELECT GOOSEBERRIES.}

\section{Set 4 to 5 feet apart each way.}

Columbus. Greenish yellow. Fruit large, handsome, of excellent quality. The plant is vigorous and productive, and does not mildew. It merits a place in every garden. The editor of The Rural New-Yorker says :

It is the best variety yet introduced, and seems close to a perfect Gooseberry for our climate.

Downing. Greenish white. July 15 here. Fruit large, oval. Plant very vigorous and hardy, with stiff, strong shoots. Foliage heavy, covering the fruit from the sun and resisting mildew. Bears most abundantly, and is profitable for market and home use. The best of all the American varieties.

Houghton's Seedling. Pale red. Fruit small to medium size, roundish, oval, sweet. Very productive and valuable.

Industry. Dark red. Fruit large, oval, hairy. Although a foreign variety, it has succeeded admirably, and we have fruited it with great satisfaction for several seasons. Attains a marketable size very early in the Gooseberry season, thus commanding the high prices of the early market. Bears enormous crops. A remarkably vigorous plant. Flavor excellent. Origin, England.

Pearl. Yellowish green. Fruit extremely large ; quality good. The plant is an extremely heavy bearer, and has been found to be entirely free from mildew. A 3-year-old bush is reported as having about 2,500 berries. A seedling of Houghton.
Smith's Improved. Light green when ripe. About July 10 here. One of the largest American varieties. Fruit oval in form, sweet and excellent. Plant vigorous, healthy and hardy. Raised from seed by Dr. Smith, of Vermont.

White Smith. Yellowish white. About July 15 here. Fruit large, roundish, oblong and smooth; slightly downy. Flavor firstrate, and generally succeeds well.

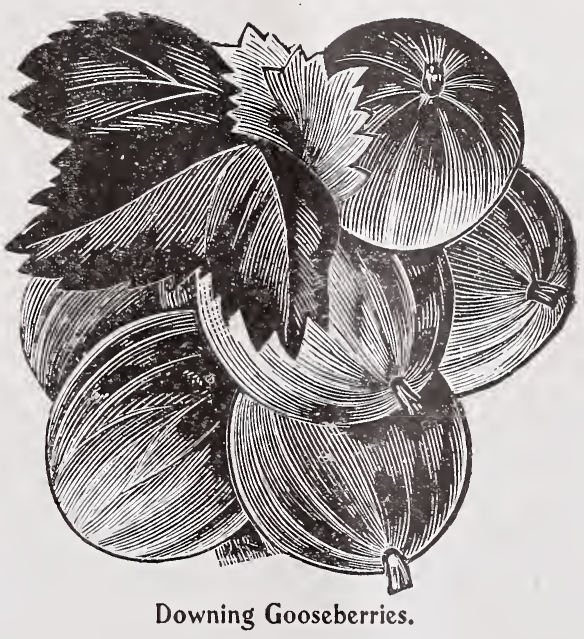




\title{
ORNAMENTAL TREES.
}

\author{
For Street, Avenue, Park, Cemetery and Lawn.
}

BASSWOOD. (See Iinden, American). BEECH, Purple-leaved (Fagus purpurea). Hardy and a rapid grower after it gets well established in the ground; long-lived; but few insect enemies. The foliage in the spring is deep purpie, and later in the season changes $t_{0}$ crimson, and again in the fall, to a dull, purplish, green, making an ornamental and attractive contrast with the green of other trees. Suitable for lawn. When fully grown, 30 to 50 feet high.

BIRCH, Cut-leaved (Betula Laciniata pendula). One of the most popular and desirable of all the weeping or pendulous trees. The bark of the tree, upon its upright trunk and larger spreading branches, is a beautiful, clean, bright white, or in some cases a little silvery. The smaller branches all have a graceful drooping habit, set with attractive leaves, of a rich, glossy green, dainty and deeply cut. The tree is a fairly rapid grower when once established and is perfectly hardy, full grown specimens standing in Minnesota where the mercury drops to 40 degrees below zero. Is now quite extensively used for street and avenue planting, the lower branches being all trimmed off close to the trunk up to a height of 7 to 9 feet. Suitable for street, cemetery or lawn. When full grown 40 to 50 feet high.

The tall, slender, yet vigorous growth, silvery white bark, small and gracefull drooping branches, with their delicateiy cut foliage combine attractive eharactertics, and is for a dainty, elegant effect, adding richness to any place, plant this tree.

BIRCH, Young's Weeping (Betula Youngii). The trees, when delivered, are about 4 to 6 feet high; the trunks grow practically no taller, and the growth of the branches is in general curving downward, forming a pendulous head, drooping to the ground in fine, thread-like shoots. The leaves are a handsome green.

BOX ELDER. (See Maple, Ashleaved.)

BUTTERNUT. (See Walnut. Butternut.

CATALPA, Sy ringa-leaved (Syringefolia). A rapid-growing, spreading, irregular tree, with very large, heartshaped leaves. Produces pyramidal clusters of white and purple flowers a foot long in July, when few trees are in bloom. Blossoms fragrant. When fully grown, 25 to 35 feet high. A native of the southern states. Suitable for lawn and street. Gives a desirable and effective tropical look to the place.

Chestnut, American (Castanea Americana). Among our large collection of ornamental, native forest trees, the Chestnut is unrivalled for its beauty. When grown in open ground, it assumes an elegant, symmetrical form. The foliage is rich, glossy and healthy, and the whole tree is covered in early summer with long, pendant tassel-like blossoms, making a handsome appearance. It is especially desirable for the sweet, eatable nuts (who does not like to go chestnutting?) which it bears profusely a few years after transplanting. Desirable for shade for avenues. The

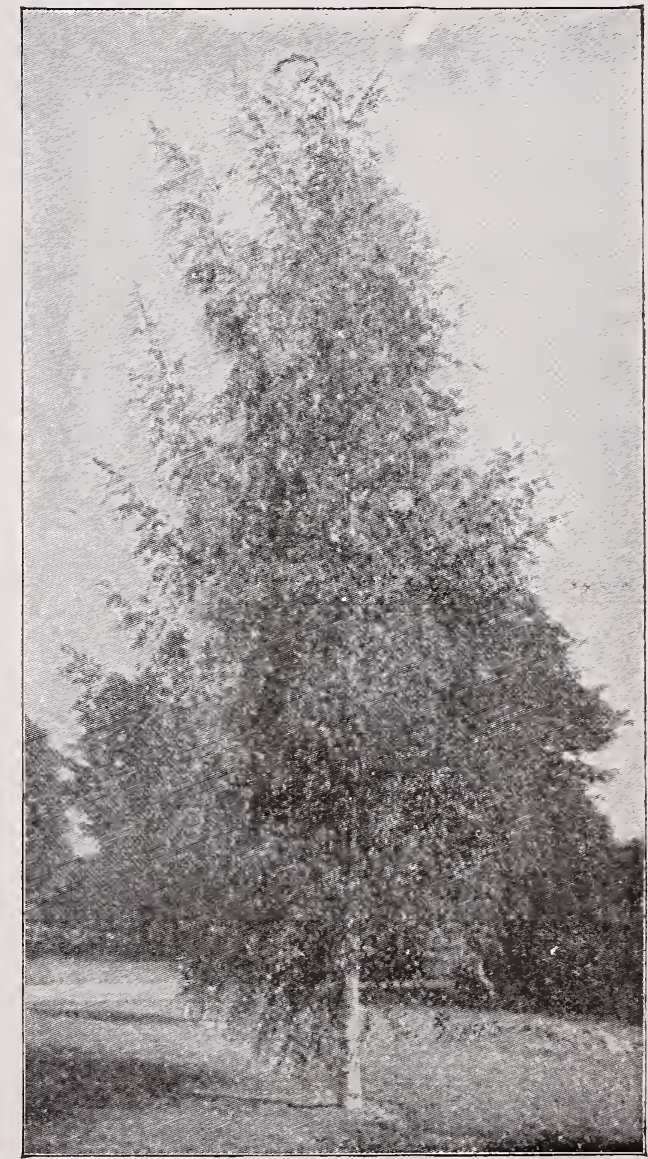

Cut.Leaved Birch. 
Chestnut thrives well on any soil except a wet one. When nursery-grown, bears transplanting well, and when once established, is a rapid grower and soon comes into bearing. Grows very high. Suitable for both lawn and street.
FRINGE, Purple (Rhus continus). A low tree or shrub, very much admired on account of its peculiar fringe, or clusters of feathery, hair-like flowers, covering the whole surface of the bush in midsummer, giving an appearance of a cloud of smoke or mist. Also known as Smoke Tree. Hardy, and adapted to almost any soil. It grows 10 to 15 feet high, and should be allowed room to spread. Suitable for lawn purposes.

FRINGE, White (Chionanthus Virginica). A small native tree or shrub. Forms a low, rounded head, and blooms profusely in late May and June. Flowers are drooping recemes of pure white. Very singular in appearance, resembles bunches of white silken fringe hung gracefully from the branches. Leaves large, glossy. Suitable for lawn purposes.

ChESTNUT, Spanish (Castanea Vesca). A valuable species, for ornament and fruit. A large, handsome lawn tree. The fruit is larger than the American Sweet Chestnut. Suitable for both lawn and street.

ELM, American White (Ulmus Americana). A native tree of large size and majestic appearance, whose high arching branches, sprear'ing gracefully over the lawn, drive or walk, or roadway, give an abundant shade, and yet a chance for air to circulate freely under its branches. A rapid grower, long-lived. Very popular in nearly all sections. Succeeds admirably where the soil is somewhat heavy and damp. When fully grown, 30 to 40 feet. Suitable for lawn or street.

ELM, Camperdown (Ulmus Camerdown pendula). Trees, when delivered, are from 5 to 8 feet tall, and trunk grows practically no taller. The branches make a zigzig growth outward and downward for several feet in a single season, forming one of the most picturesque and handsome drooping trees. The head can be grown, in time, to attain a size of 10 to 20 feet across it. Leaves are of a dark, glossy green, of large size, completely covering the tree, forming a luxuriant mass of verdure. A strong, rapid grower. Specimens by a little training will form a little arbor or play house, branches and leaves forming ceiling and walls. Suitable for lawn or garden.

ELM, English (Ulmus Campestris). Forms a tall, erect tree, with slender branches and small leaves. The branches project from the tree at almost right angles, making a very handsome appearance. When fully grown, 30 to 40 feet. Suitable for lawn or street. A native of Europe.
HORSE CHESTNUT (Esculus Hippocasianum). A very beautiful, round-headed, regular outlined tree. Admirable for its symmetry, its profusion of dark green foliage, and large

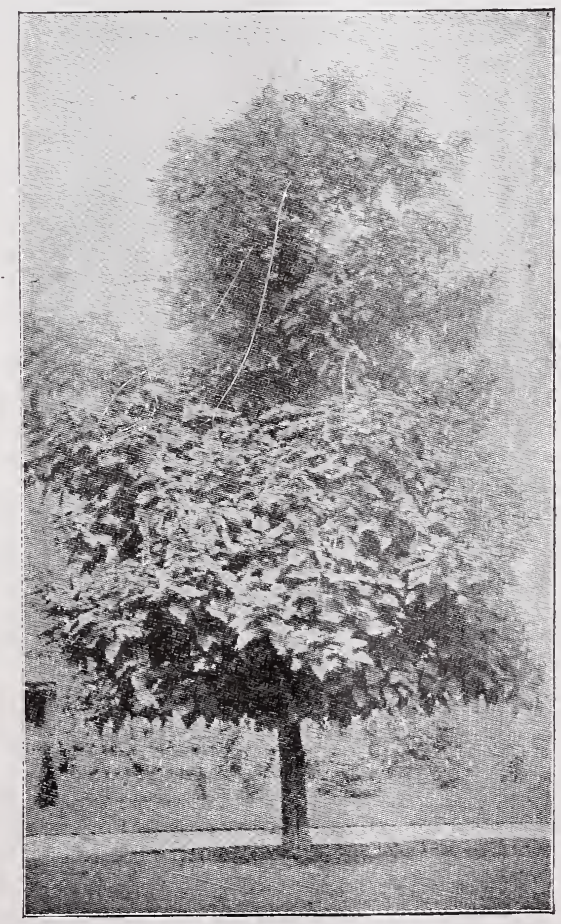

Catalpa, Syringa.Leaved. 
pyramidal spikes of white flowers in the spring; is very hardy and free from disease. Foliage very profuse, making a dense shade. Makes a large-sized tree, 30 to 50 feet high. Suitable for street and lawn.

LINDEN, American, or Basswood (Titia Americana). A rapid-growing, large, symmetrical, native tree, with very large leaves, making an open-headed or spreading growth. Foliage luxuriant. In midsummer a profusion of fragrant yellow flowers hang in large clusters. Easy to transplant, and will grow in most any soil. When fully grown, 40 to 50 feet high. Suitable for street or lawn.

LINDEN, European (Tilia Europcea). A small, more compact, more pyramidal grower than the American Linden. Leaves large. Flowers fragrant. Foliage dense. Growth symmetrical. When fully grown, 30 to 50 feet high. For lawn or street planting.

MAGNOLIA, Acuminata (Cucumber Magnolia). A beautiful pyramidal-growing, symmetrical tall tree. Leaves bluish green, and 6 to 9 inches long. Flowers yellow, tinted with bluish purple. Bears fruit that resembles a cucunber when green, from which comes the name. The stateliness of form, size and richness of foliage,and lavish yield of fragrant flowers make the Magnolia very desirable. We advise only spring planting for all Magnolias. Grows from 50 to 70 feet high. Particularly desirable for lawn, singly or in groups, and also used for avenues.

MAGNOLIA, Soulangeana. Shrub-like in its growth, particularly while young, but becomes a fair-sized tree. Flowers are white and purple, cup-shaped, 3 to 5 inches in diameter, very fragrant, and appear at the first approach of warm weather in the spring, before the leaves appear. The appearance of a wellgrown tree, with its abundance of flowers, fully expanded so early in the season, when there are so few blossoms, and while the tree is without leaves, is a most beautiful sight. Foliage is large, glossy. Makes a fair-sized tree. Suitable for lawn. We advise spring planting for all Magnolias.

MAGNOLIA, Speciosa. In growth and foliage, this tree is similar to $M$. Soulangeana. Flowers are a little smaller in size, and appear about a week later. In color are white. It is a very desirable variety. For the lawn. We advise spring planting for all Magnolias.

MAIDENHAIR. See Salisburia.

MAPLE, Ash-leaved (Box Elder). (Acer Negundo.) A rapid grower, of irregular, spreading habit. Foliage is Ash-like; seeds are Maple-like. Very hardy. Grows 50 to 60 feet high. For street or lawn. A native variety.

MAPLE, Japanese, Blood-leaved. Very small growing tree. Its adaptability to so many situations in planting arrangements, its blood-red foliage, making a striking contrast with its surroundings, and its compact, regular growth, make it a most useful ornamental plant. It can be used as a single specimen, in groups of three or four, or in beds of large-growing shrubs. As a single specimen on small lawns as it has no equal.

MAPLE, Norway (Acer Platanoides). Grows to large, handsome tree,forming a spreading, rounded head. Foliage broad, shining, deep green. Shade dense. Is universally planted. The compact habit and stout, vigorous growth render it one of the most desirable trees for avenue, park or street planting. In nursery row, is inclined to grow a little rough and a little crooked, but straightens into a fine tree. When fully grown, 30 to 50 feet high. A native of Europe. Extensively used for street, avenue and park purposes and for lawn.

MAPLE, Rock. (See Maple, Sugar.)

MAPLE, Silver-leaved (Acer Dasycarpum). Grows rapidly to be of large size, forming an irregular, rounded head. Leaves bright green above and silvery white beneath. Tree transplants nicely, and hardy. Useful when quick shade is desired. Suitable for park, street and lawn. When full grown, 50 to 60 feet.

MAPLE, Sugar or Rock (Acer saccharinum.) Valuable for its production of sugar sap (maple sugar), while its fine shape and foliage make it desirable as a shade and ornamental tree. Form of growth is pyramidal. Well adapted for most all soils. Grows 50 to 60 feet high. For street or lawn planting. A native variety.

MAPLE, Weir's Cut-leaved (Acer Weirii laciniatum). One of the most remarkable and beautiful trees, with cut or dissected foliage. Its growth is rapid, shoots slender and drooping, giving it a habit almost as graceful as the Cut-leaved Birch. The foliage is abundant, silvery underneath, and on the young wood especially deeply and delicately cut. The leafstalks are long and tinted with red on the upper surface. It ranks among the most interesting and attractive lawn trees, and may be easily adapted to small places by an occasional cutting back, which it will bear to any degree necessary, as well as a willow. Lawn. Grows 40 feet high.

MOUNTAIN ASH, American (Sorbus Americana). A favorite, erect growing tree, of medium size, producing white flowers early in spring, followed by clusters of bright scarlet berries, which remain on the tree through the winter months. When fully grown, from 25 to 30 feet high. Suitable for lawn.

MOUNTAIN ASH, European (Sorbus aucuparia). A small pretty tree, with white, pinnate foliage. Bears numerous clusters of bright red berries, which are very handsome and conspicuous from midsummer until frost. When fully grown, 25 to 30 feet high. Suita. ble for lawn. 
ASH, Oak-leaved (Sorbus quercifolia). A distinct and desirable tree, with compact, pyramidal head and dark lobed leaves, downy underneath; produces the same flowers and berries as the American or European Mountain Ash. Very hardy, and desirable for planting on lawns or in door yards. When fully grown 20 to 25 feet high.

ASH, Weeping (Sorbus aucuparia pendula). Trees, when delivered, are from 5 to 8 feet high, and grow practically no taller. The branches are of a straggling, pendant character, twisting and turning in all directions, Covered during the autumn with bright red berries. Suitable for lawn.

MULBERRY, Downing. Valuable as a shade tree and for its fruit. Berries are of a large size, black, excellent quality, ripening about the middle of July, and continuing to ripen for several weeks. Tree is a rapid grower, of pleasing shape, and perfectly hardy here. When fully grown, 20 to 30 feet. Suitable for lawn.

MULBERRY, New American. Fruit large and of fine quality. Tree is a rapid grower and hardy here, bearing delicious fruit, beginning about the middle of July until autumn. Leaves are large, and of a dark, glossy green. When fully grown, attains a height of from 25 to 30 feet. A very attractive lawn tree.

MULBERRY, Teas' Weeping (Morus Pen$d u l a)$. One of the finest and most graceful weeping trees, forming an umbrella-shaped head, with slender, willowy branches drooping to the ground. The foliage is a beautiful, glossy green, handsomely cut or divided into lobes. Tree perfectly hardy, enduring the severe cold of the

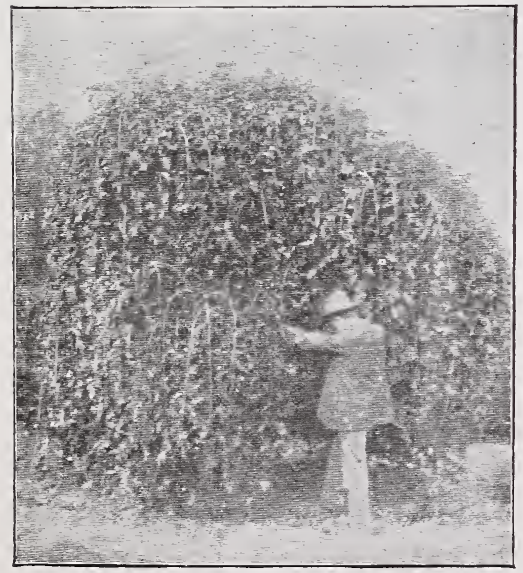

Weeping Mulberry.

north and extreme heat of the south. The main growth of the branches of this class of weeping trees is downward, and the tree does not attain any additional height of any amount after it is set out. Trees are in the neighbor. hood of 5 to 8 feet high when delivered. Suitable for lawn.

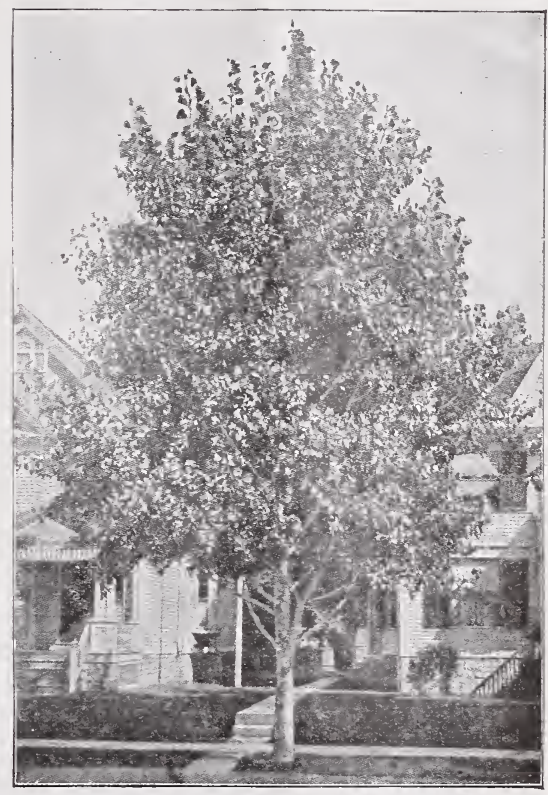

\section{Carolina Popular.}

POPLAR, Carolina (Populus Caroliniana). There is a brisk demand for a shade tree of quick growth, and here it is. One of the most desirable trees for street planting as it will withstand lots of hardships. Extensively used for screen purposes where a high growing screen is wanted. Particularly desirable where a tree of quick growth is wanted, either in lawn or street. Tree is pyramidal in shape. Leaves are large, green and glossy. When fully grown, 50 to 60 feet high.

POPLAR, Lombardy (Populus fastigiata). The tree is remarkable for its very erect, tall, spire-like form, breaking the ordinary and monotonous outline of most other trees. It is an extremely rapid grower. Suitable for street or lawn. Attains a height of from 75 to 100 feet or more.

SALISBURIA Adiantifolia (Maidenhair). An elegant tree of singular habit, combining characteristics of the conifer and deciduous tree, with large branches, spreading horizontally, irregular lengths. Leaves resembling the Maidenhair fern. Fruit and seeds, or nuts, are edible. Origin, Japan. Desirable for lawn. A medium-sized tree.

SMOKE TREE. See Fringe, Purple.

THORN, Paul's (Cratoggus Paulii). Dense low-growing tree, occupying comparatively little space, and weil adapted to beautify small 
grounds, or for use where a low screen is wanted. Flowers a bright carmine-red, making a noticeable and handsome, and one of the most desirable, flowering trees. Foliage attractive. Tree hardy. Desirable singly or when planted in groups or masses. Planted with Thorn White, makes a rich appearance. Suitable for lawn. Grows 12 to 20 feet high.

THORP, White (Cratogus Alba). A highly ornamental variety on account of its foliage and its profusion of small, pure white, double flowers. Planted with the Paul's Thorn, it makes a handsome effect. Suitable for lawns. Grows 12 to 18 feet high.

TULIP TREE (Liriodendron tulipifera). One of the largest and most stately native forest trees. The trunk is usually perfectly straight and cylindrical for a great height. A very rapid grower. Bears a profusion of large, tulip-shaped flowers. Leaves large, glossy, light green, shaped like a riolin. Desirable for street or lawn, and where a rapid growth is de- sired. Transplants to best advantage when not too old or too tall. When fully grown, 50 to 60 feet high.

WALNUT, Black (Juglans nigra). A native species, of very great size and majestic habit. The bark is very dark, rough and deeply furrowed. The foliage is very beautiful, each leaf being composed of 13 to 17 leaflets. The nut is round. Suitable for street, lawn or grove, Grows 60 to 80 feet high.

WALNUT, Butternut (Juglans cinerea). A native tree of medium size, with a spreading head. Bark is grayish. Nut oblong and rough. Suitable for street, lawn or grove. Grows 40 to 60 feet high.

WALNUT, English (Juglans regia). Also called Madeira Nut. A fine, lofty-growing tree, with a spreading head. Bears crops of large, excellent nuts. Nut oval, and very nice. Suitable for street, lawn or grove. Grows 40 to 60 feet high.

WILLOW, Kilmarnock (Salixcaprea pendulum). W. en delivered, are about 5 to 8 feet high, and the trunk practically grows no taller, the growth of the branches being curved downward, forming an open umbrella shaped top, with the branches drooping gracefully to the ground. Leaves are a glossy green. Tree is hardy and vigorous, and thrives in most all soils. Requires but little trimming; only enough to preserve the desirable rounded head and to keep the drooping branches the same length. Suitable for cemetery lots or for lawns, and very desirable and useful where a low screen is wanted.

\section{WILLOW, New Ameriean Weeping (Salix purpurea). A} dwarf species of Willow. When delivered, is about 5 to 8 feet high, and the trunk of the tree grows practically no higher. The growth of the branches is outward and downward. Hardy, and very pleasing. Suitable for lawn. Also known as the Fountain Willow. Origin, Europe. 


\section{EVERGREENS.}

Trees, Plants and Hedge.

FVERGREENS are difficult to transplant. They should never be set in the fall except in the South, and great care must be taken to avoid all exposure to sun or wind. It is advisable to prepare the places for setting (or if a hedge; the strip where the hedge is to stand) before the Evergreens are unpacked or brought into the sun. In setting a hedge, do not strew the plants along the line where the hedge is to stand, as is often done, for this exposure to wind and sun is almost fatal. But few plants at a time should be carried into the sun, and these properly set as fast as possible.

ARBORVIT EE, American (Thuja occidentalis). A well-known native variety, commonly known as the White Cedar. Forms an upright, conical tree, of only medium size. Grows rapidly, and by easy management it soon forms a most beautiful hedge, very dense and perfectly impervious to the sight. It is not adapted to turn live stock, but is most desirable and ornamental to divide the lawn from the other parts of the grounds, or for cemetery purposes. Holds its green color throughout the entire year. It is often planted irus.ridually in the lawn or cemetery. Hardy.

For hedge purposes, only small-sized plants should be user, as they withstand the shock of transplanting better than oider plants. For hedge, set plants about 2 feet apart, trimming in April or May, just before the new growth starts. We recommend moderate trimming or shearing each season, rather than to let it go several years and then trim excessively.

CEDAR. See Arborvitæ, American.

JUNIPER, Irish (Juniperus Hibernica). A very pretty tree or shrub, forming a neat, tapering, almost cylindrical column of dark, deep green, right from the ground up, as branches start close to the ground. Remains green all the year. Very hardy. Desirable for planting on lawns or in cemetery lots, where larger evergreens are not admissable. Never grows very tall, and never becomes broad, as the branches grow almost straight up, parallel with the main body.
PINE, Austrian or Black (Pinus Austri$a c a)$. From Central Europe, where it grows over 100 feet high. Remarkably robust, with long, stiff leaves and deep green foliage. Hardy everywhere. Valuable for planting as windbreaks and screens, or for the lawn.

SPRUCE, Colcrado Blue (Abies pungens). Hardy. Foliage of a rich blue color, of a fine compact habit, and of very symmetrical growth, becoming a spreading, stately tree. Distinct from other lawn adornments on account of its silvery blue foliage.

SPRUCE, Norway (Abies Excelsa). Dense in structure, and when left natural, will branch close to the ground. Of very rapid growth. Has a gracefully drooping habit when of some size. Shape of the tree is pyramidal. Perfectly hardy. Will bear shearing or cutting well, and hence is well adapted for planting in hedges or screens, or for cemetery hedge. Also suitable to plant individually. Holds its green color throughout the entire year.

We recommend moderate trimming or shearing each season, rather than to let it go several years and then trim excessively. For hedge, set plants a bout 2 feet a part, trimming in April or May, just before the new growth starts.

The Norway Spruce is used for "Christmas trees" probably more extensively than any other Evergreen. 


\section{HEDGE PLANTS.}

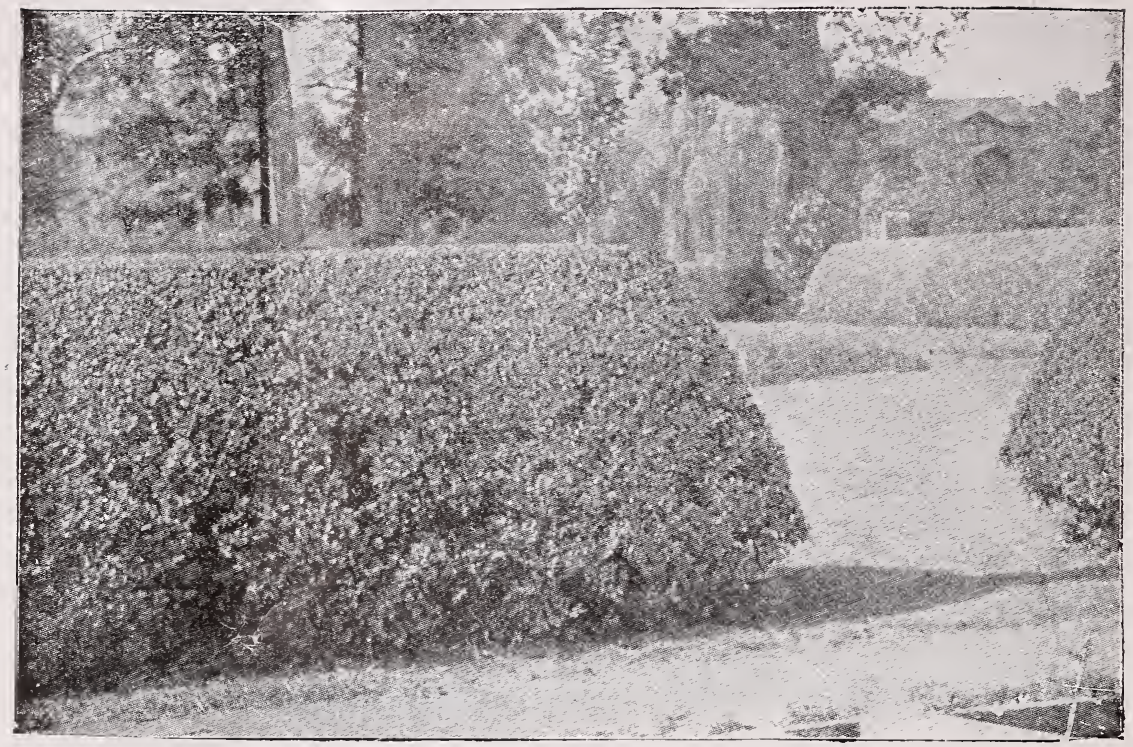

\section{Mudige of Calitornia Privet.}

$\mathrm{H}^{\mathrm{ED} G E S}$ are valuable as a defence against animals, as windbreaks to protect orchards, gardens or farms unduly exposed, and as ornamental fences or screens to mark the boundaries of a lawn or cemetery lot.

\section{Hedges for Defense.}

Honey Locust. For turning cattle and as a farm hedge, Honey Locust is much the best. It is of vigorous growth, perfectly hardy ; thrives with ordinary care, and is sufficiently thorny to be impenetrable. It bears the shears well.

Plant 9 to 12 inches apart, or a very dense hedge for defense or ornament can be made by planting in two rows, about 9 inches apart and setting the plants in the rows alternately.

Hedges as an Ornamental Fence or Low Screen, for Lawn or Cemetery.

California Privet (Ligustrum ovalifolium). Hardy. A free, compact grower in most all manner of soils. Bears shearing well. Valuable and handsome for hedge. Should be severely headed-in at planting, to make it throw up numerous shoots at the base. Without such shoots at the base a good hedge cannot be made. Old hedges of this species that have lost their lower branches may be renovated by cutting down to within 6 to 10 inches of the ground in the spring, before growth begins, when numerous new strong shoots will come out from the stubs, and soon a new and wellformed hedge will result.

Quince, Japan. [See description undeI Ornamental Shrubs.]

American Arborvitæ and Norway Spruce, described under Evergreens, are de sirable for this use.

\section{Hedges for Windk-zaks, or High Screens.}

Norway Spruce is best. Its vigorous hab. it, rapid, dense growth, large size and entire hardiness, are characteristics not easily obtained in any other evergreen. For description, see under Evergreens.

\section{American Arborvitæ comes next.}

Belts of Pines are also useful as a protection. For descriptions, see under Evergreens. 


\section{ORNAMENTAL SHRUBS.}

THESE are much smaller than trees, and occupy less space. They are very valuable planted as single specimens in the door yard, or in groups or masses. The proper use of the pruningknife or shears will keep the plants in handsome shape and proper size.

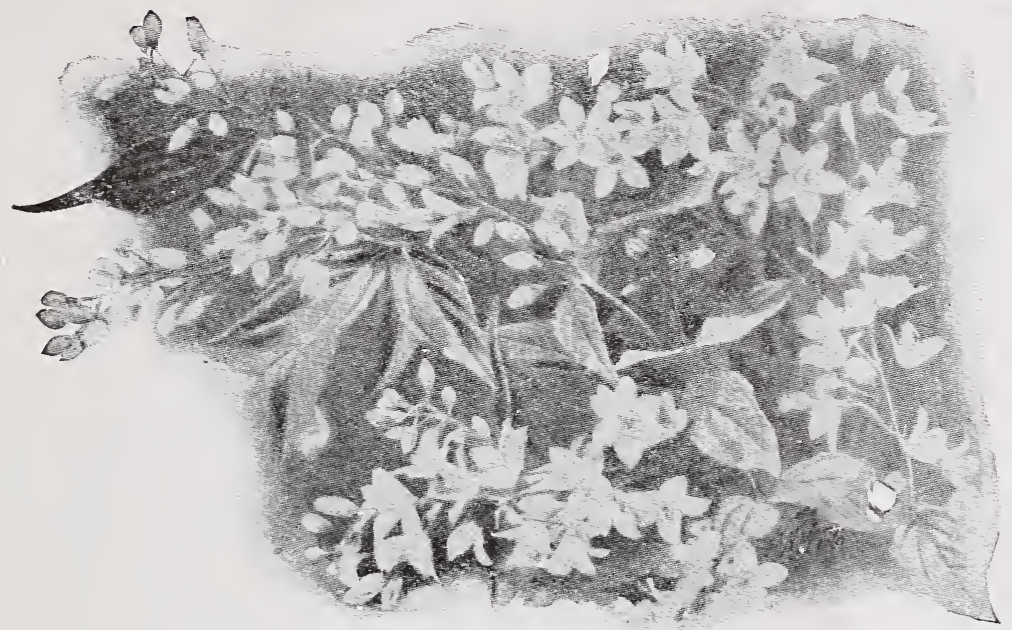

Deutzia Gracilis.

ALTHEA, or Rose of Sharon (Hibiscus). Fine, hardy, free-growing and flowering shrubs of the easiest cultivation. Very desirable on account of blooming in August and September, when scarcely any other tree or shrub is in blossom. The flowers are large, and bloom freely, covering the shrub. The beautiful colors of the different varieties contrast admirably with each other.

Althras can be trimmed and grown tree shape, attaining from 6 to 10 feet in height, making a handsome and compact little flowering tree, or they can be grown in bush form, making a large shrub.

ALTHAEA, Double Blue, Double White, Double Purple, Double Red. These varieties are distinguished by the color of the blossoms, each being the same in habit and foliage. Order by color.

ALTHAEA, Variegated-leaved ( $f l . p l$. , fol. var.) A conspicuous variety, with leaves distinctly marked with light yellow, and having double purple flowers; showy and desirable. One of the finest variegated-leaved shrubs.

AZALEAS, Hardy. Ghent Hybrid Azaleas combine a great variety of colors, and possess a delightful perfume. They blossom during the months of May and June, and are among the best plants for borders or beds for decorating lawns and grounds. Do not grow tall.

AZALEAS, Hardy. Mollis. A splendid hardy species from Japan, and one of the most valuable flowering shrubs. The flowers combine a iarge variety of colors, and are borne in large clusters, in such profusion as to. entirely hide the plant. Very desirable ornamental shrub for the lawn, and excellent for the front of borders and clumps of tallergrowing shrubs. Do not grow tall.

BARBERRY, Purple-leaved (Berberis purpurea). One of the smallest purple-leaved shrubs, and one of the handsomest, growing from 3 to 5 feet high, with violet-purple leave:. Its showy golden flowers in May or June are succeeded by violet-purple fruits. Very ornamental in the autumn and early winter, as the leaves retain their dark purple color through the season. It is especially desirable to plant in the foreground of golden or light green-leaved trees or shrubs. Can be brought into bushy form by a little pruning. when young. Desirable planted singly or in groups.

CALYCANTHUS, or Sweet-scented Shrub. A very hardy, vigorous-growing shrub, with: brown or chocolate colored, very sweet scented flowers.... Blossoms in J? : and at intervals thereafter; the flowers are produced from the axils of the leaves all along the branches; that is, a branch has flowers along its entire length in the same position as its leaves. The wood is fragrant. Calycanthus grows well in most all kinds of soil, and attains a height of 5 . to 6 feet. Leaves handsome in color, soft, down beneath. Also called Strawberry Tree. 
DEUTZIA. The Deutzias are from Japan. Their hardihood, fine habit, luxuriant foliage and profusion of attractive flowers place them among the most popular of our flowering shrubs. "Their flowers are produced the latter part of June, in racemes 4 to 6 inches long.

DEUTZIA, Crenata. A tall, upright-growing shrub, with dark green leaves and pendant racemes of pink or white flowers. It tends to grow with few lower branches, and some of the inside canes need cutting out occasionally to make it branch. Flowers very double, white, tinged with rose.

DEUTZIA, Gracilis. One of the most beautiful small shrubs, covered with a profusion of spikes of pure white flowers in June. This is well adapted to planting in cemetery lots, or small door-yards. Fine for pot culture, as it fowers freely in low temperature during the winter.

DEUTZIA, Pride of Rochester. Flowers large, double white, back of petals slightly tinged with rose; superior to others in size of flowers, profusion of bloom and vigorous habit. Blooms a week earlier than Deutzia Gracilis.

DOGWOOD, Variegated. Cornus Siberica variegata. Beautiful shrub of large size. The branches are bright red, and with the snow for background are especially valuable for winter effect. The leaves are very beautifully variegated with yellow, white and green, and make a very pleasant contrast with dark green or purple leaved shrubs. One of the prettiest variegated shrubs in cultivation, and worthy of more general planting.

FRINGE. See under Ornamental Trees. ,

HONEYSUGKLE, UPright (Lonicera). Makes a very large, upright shrub, with flowers that are followed with berries. Blooms in the spring from the old wood.

HONEYSUCKLE, UP right. Red Tartarian ( $\mathrm{Ta}$ trrica rubra). Beautiful flowering shrub, blossoming in June. Bright reddish flowers, followed by bright scarlet berries, that contrast beautifully with the foliage.

HONEYSUCKLE, Upright. White Tartarian (Tatarica alba). Forms a high bush, with creamy white, fragrant flowers, followed by berries. - Blooms in May and June.
For Honeysuckle Vines, see under Har. dy Climbing Vines.

HYDRANGEA, Paniculata grandiflora. A fine shrub, attaining a height of 6 to 10 feet. Strictly hardy. Flowers, produced in great panicles, are at first pure white, then changing to pink. Begins to bloom early in August, continuing several weeks. Foliage is handsome in shape and of a desirable green color. It is valuable for planting either singly or in beds. No one makes a mistake in planting this variety; it is and should be extensively planted. To get the best results in growing this shrub, the new growth should be cut back in the fall, or before growth begins in the spring. This Hydrangea can be grown in the form of a small tree by trimming off the lower branches, and it is very attractive and desirable in this form. "Decidedly the finest flowering shrub of recent introduction."

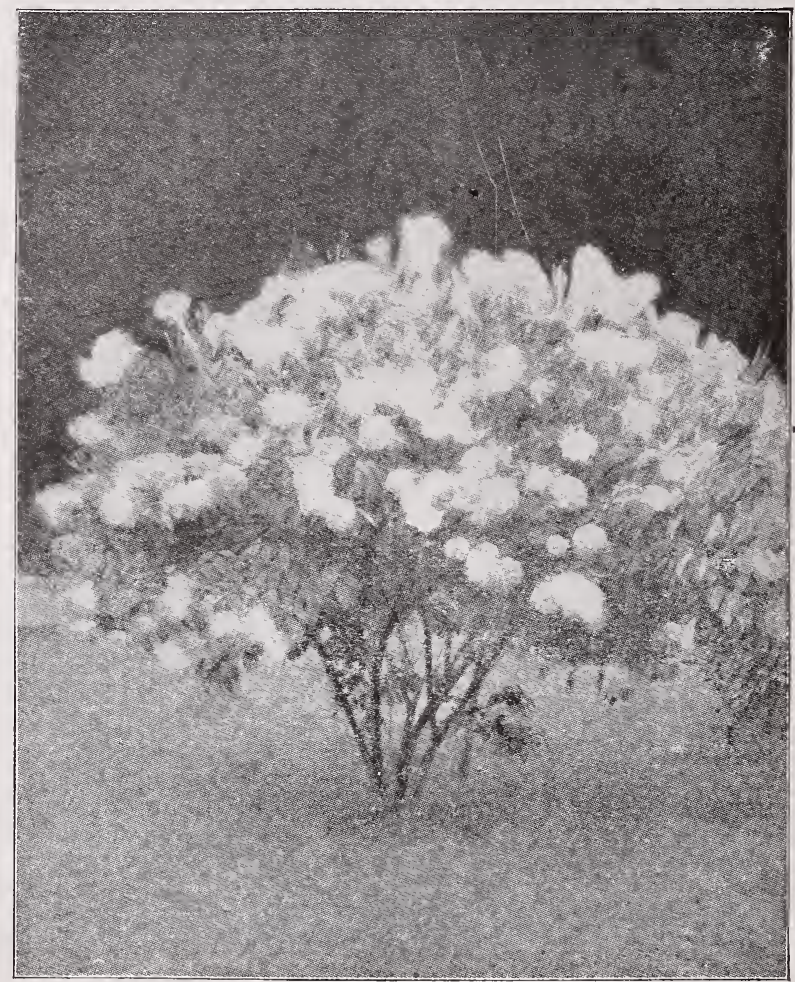

Hydrangea Paniculata Grandiflora.

HYDRANGEA, Otaksa. Beautiful, deep green foliage. The plant produces immense trusses of rose-colored flowers in profusion in July. Free bloomer. Requires protection in winter; should be grown in pots or boxes and wintered in the cellar, and in summer placed on stoops or along walks under the trees. 
LILAC, (Syringa). A class of medium-tolarge-growing shrubs, with bright, attractive, glossy green foliage and a profusion of various colored clusters of flowers, delightfully fragrant. They flower in May and June. All the varieties below are choice, much superior to the old fashioned single lilacs of long ago, the growth of bush being more trim and neat, the flowers much more showy and the foliage is bright and attractive.

LILAC, Persian Lilac. This Lilac is of medium size, with small. bright green leaves and large compound panicles of rather brighter flowers than the old-fashioned Lilac. The bush is of graceful outline. There are two kinds, one with red flowers, the other with white flowers. In ordering, specify as Lilac, Persian Red; or, Lilac, Persian White.

MAPLE, Japan. See description under Maple, in Ornamental Trees.

MOCK ORANGE. [See Syringa].

PAEONIES. [See under Bulbs and Perennial Herbaceous Plants.

QUINCE, Japan (Cydonia Japonica.) There are several flowering varieties, differingonly in the color of the flowers. Although of straggling growth, they can be pruned to desirable shapes without injury. Their large, brilliant blossoms appear in great profusion early in the spring, before the leaves unfold and produce a very brilliant and pleasing effect. Foliage bright green and glossy all through the summer. Desirable planted alone or in groups. It is sufficiently thorny and strong for a hedge, and its beautiful fiowers make it very desirale for that purpose.

ROSE OF SHARON. [See Althea].

RHODODENDRON. An ev. ergreen shrub. The broad ever green leaf, with its glossy richness, a handsome green through the entire winter, would alone entitle the Rhododendron to the first rank, but when it is crowned in June with many clusters of flowers, each cluster

LILAC. Dr. Breitschneider. A new uprightgrowing sort, forming a compact, tree-like shrub, and flowering at the end of almost every shoot. The flowers are a dark lavender, and are borne in such profusion that the plants, when in bloom, are a magnificent sight. Thick, leathery leaves, much like those of the Japan Snow Ball. A very distinct and handsome sort.

LILAC, Japonica (Japanese Tree Lilac). The largest of the Lilacs, making a small tree. Leaves are large, dark green, and the very large panicles of white flowers are produced in June; hardy and desirable.

LILAC, Marie Legraye. Pure white, splendid, large trusses ; strong, symmetrical grower; free-blooming. A favorite variety for forcing.

LILAC, O Michael Buchner. Pale lilac, double flowers, borne in immense panicles. A very handsome and valuable variety. large enough for a boquet, each variety having its own color-white, purple, pink, red and crimson - the word superb describes its appearance. It can be planted singly upon the lawn, or in a city garden, and is also very effective in a mass of one or two dozen. We can supply the above colors. Order by colors.

For success with Rhododedrons, a light garden soil is the best; if the soil is clay, let it be lightened with sand, leaf-mold, rotted sod or surface soil which has been heavily manured the year before, are all beneficial ; mulching is useful, but it should not be allowed to remain during the growing season from April 15 to July 15 , as the soil needs air and sun for at least three months of the year. Some liquid or surface manure can be profitably applied during growth, and as they are heavy feeders they should not be planted too close, for they need. abundant room for their roots, when properly supplied with liquid or surface manure. It is a great mistake to plant them under trees, as they will not flower as freely when thus placed as when planted in the sun. 
SNOWBALL, Common (Viburnum sterilis). Very beautiful and popular; flowers snowy

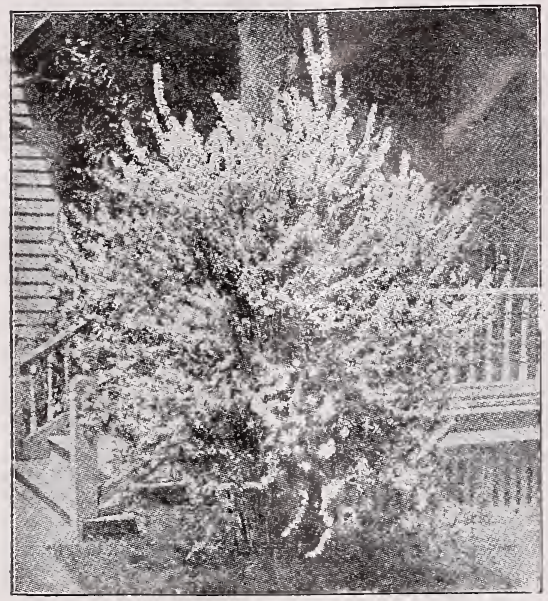

Spiræa Prunifloria.

white, borne in large balls, flowering the latter part of May. Makes a large-sized shrub.

\section{SNOWBALL, Japan ( $V i$ -} burnum plicatum). This variety is a valuable addition to the list of hardy shrubs and surpasses the common Snowball in many respects. We can recommend this with a certainty that it -rill plzase. It forms an erect, compact bush 4-6 feet high, and blossoms early in June, when the plants are covered from the ground to the tops of the branches with balls of flowers as white as snow, clustered one against the other in dense masses. Leaves are of a bright green, with a beautiful plicated or plaited surface.

SMOKE TREE. [See Fringe, Purple, under Ornamental Trees.]

SPIREAS. The blooming period of the Spiræas extends from spring to late summer, some of them flowering at a time when there is but little in bloom.

SPIRAEAS, Aurea or Golden (Opulifolia aurea). A striking variety of decided beauty, and one of the most effective shrubs for a lawn. Foliage green, bordered with a rich, goldien yellow ; very distinct a-d beautiful. In June the branches are covered with a double white flower.

SPIRAEAS. Callosa alba. A dwarf variety of the above, having pure white flowers in the greatest profusion. Very desirable on account of its dwarf habit and free-flowering.

SPIREAS. Prunifolia. (Bridal Wreath). One of the oldest and most hardy of the Spiræas. Produces long, slender branches, that in the spring are covered with beautiful white, double flowers ; these branches may be bent around so as to form a perfect wreath, whence the name. It has the habit of producing very few lateral branches, so that severe pruning should be given to a few of the strongest canes after blooming in the spring.

SPIRAEAS Van Houtte (Van Houttei). Surpassing all other Spiræas in the superb beauty and gracefulness of its blossoms. The plant is dwarf in habit,with graceful, pendulous branches which, when in bloom early in June, are weighed down with pure white blossoms, the plant being covered with a mass of flowers.

SYRINGA, or Mock Orange. (Philadelphus). Of vigorous habit; very hardy, with large, handsome foliage and beautiful white

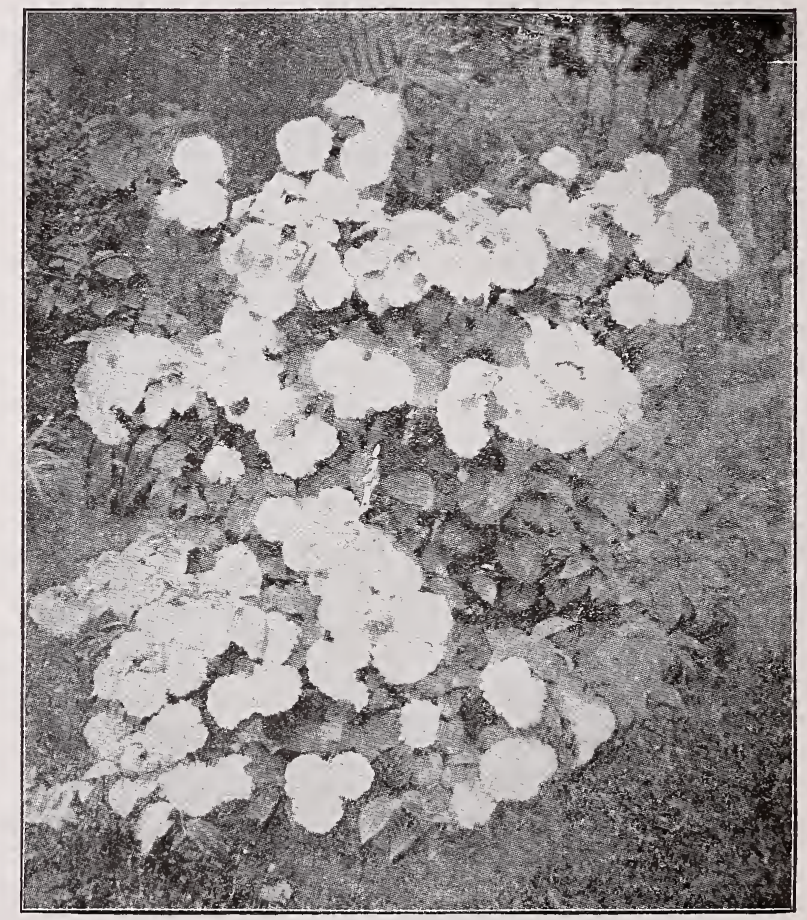

Japan Snowball. 
flowers, produced in the greatest profusion in the blossoming season. It is called the Mock Orange because its flowers somewhat resemble orange blossoms, and are equally fragrant, though with not as delicate a perfume. Except that of dwarf habit, form large-sized shrubs, 12 to 15 feet high. They can, of course, be kept smaller by pruning. All of the varieties flower in June, after the Weigela.

SYRINGA. Double-flowering ( $P$. flore pleno). A variety with partially double, fragrant flowers.

SYRINGA. Garland ( $P$ 。 coronarius). A well-known shrub, with pure white, highly scented flowers. One of the first to flower.

SYRINGA. Gold-leaf ( $P$. aurea). A dwarf variety. Flowers abundantly. A handsomely shaped plant, of medium size, with bright, golden-yellow foliage. Will be found valuable for creating pleasing and striking contrasts with shrubs of other colored foliage.

STRAWBERRY TREE. [See Calycanthus?

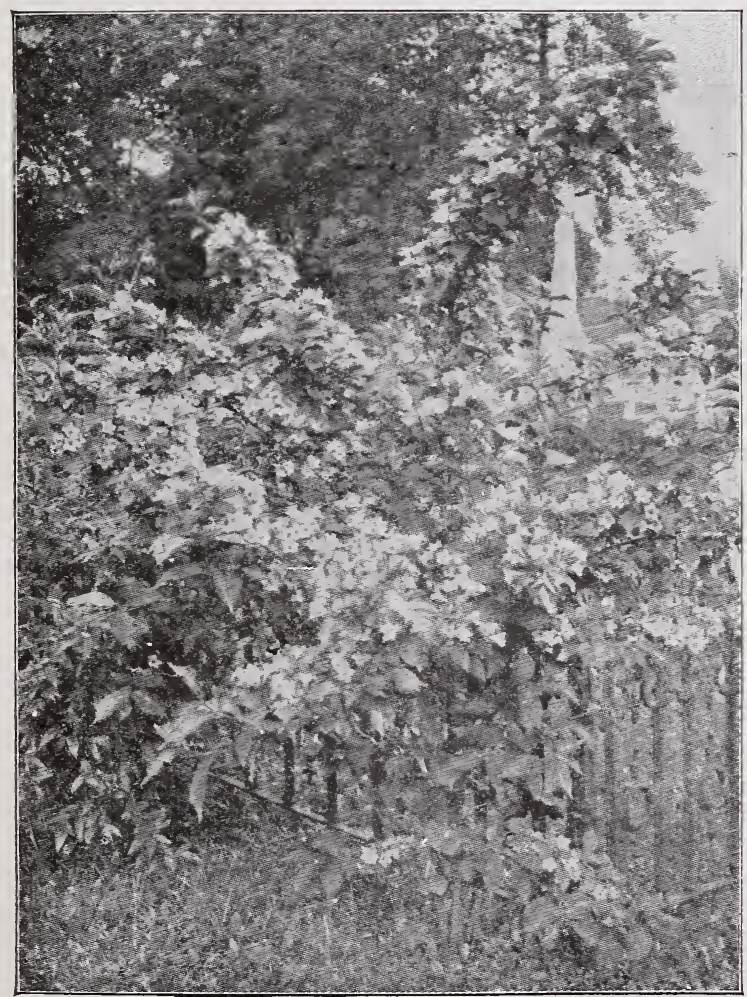

Weigela Candida.
TREE PEONIES. (Pconia Moutan). Low, handsome flowering shrubs, attaining from 3 to 4 feet in height. The flowers appear in May, and are of gorgeous colors, very numerous, and enormous in size, oft across. Very effective among other shrubs, or for borders or margins. Although hardy, the plants are greatly improved by slight protection in winter. A native of China.

TREE PEONIES. Crimson, Red, Pink. Distinguished by the color of the flower, each being the same in habit and foliage. Order by color.

TREE PEONIES. Banksii. Very large, fragrant flower ; rosy blush, with purple center.

VIBURNUM Plicatum. [See Snowball, Ja. pan.]

WEIGELA. Hardy, easily grown, and great bloomers. Of erect growth while young, but gradually spreading and drooping as they acquire age. They produce, in June and July, superb, large, trumpet-shaped flowers, and keep up a fine show of color in the shrubbery for a month or two. In borders and groups of trees they are very effective, and for margin work, the variegated-leaved varieties are admirably suited their gay-colored foliage contrasting finely with the green of other shrubs.

Some of the old wood should be cut out each year, after flowering, which will result in the growth of young, vigorous shoots, that will produce an abundance of large flowers.

WEIGELA. Candida. A strong-growing new variety, bearing pure white flowers in great profusion. One of the best.

W E I GELA. Hortensis nivea. Flowers pure white, retaining their color, and being clear enough for the choicest boquets ; foliage is large; a profuse bloomer ; of dwarf spreading habit, 3 to 4 feet.

WEIGELA. Rosea. An elegant shrub, with fine rose-colored flower's. Introduced from China by Mr. Fortune, and considered one of the finest he has discovered. Quite hardy; of erect, compact growth. Blossoms in June.

WEIGELA. Variegated. The leaves of this variety are beautifully marked with light green, white, and yellow. Flowers light rose colored. 


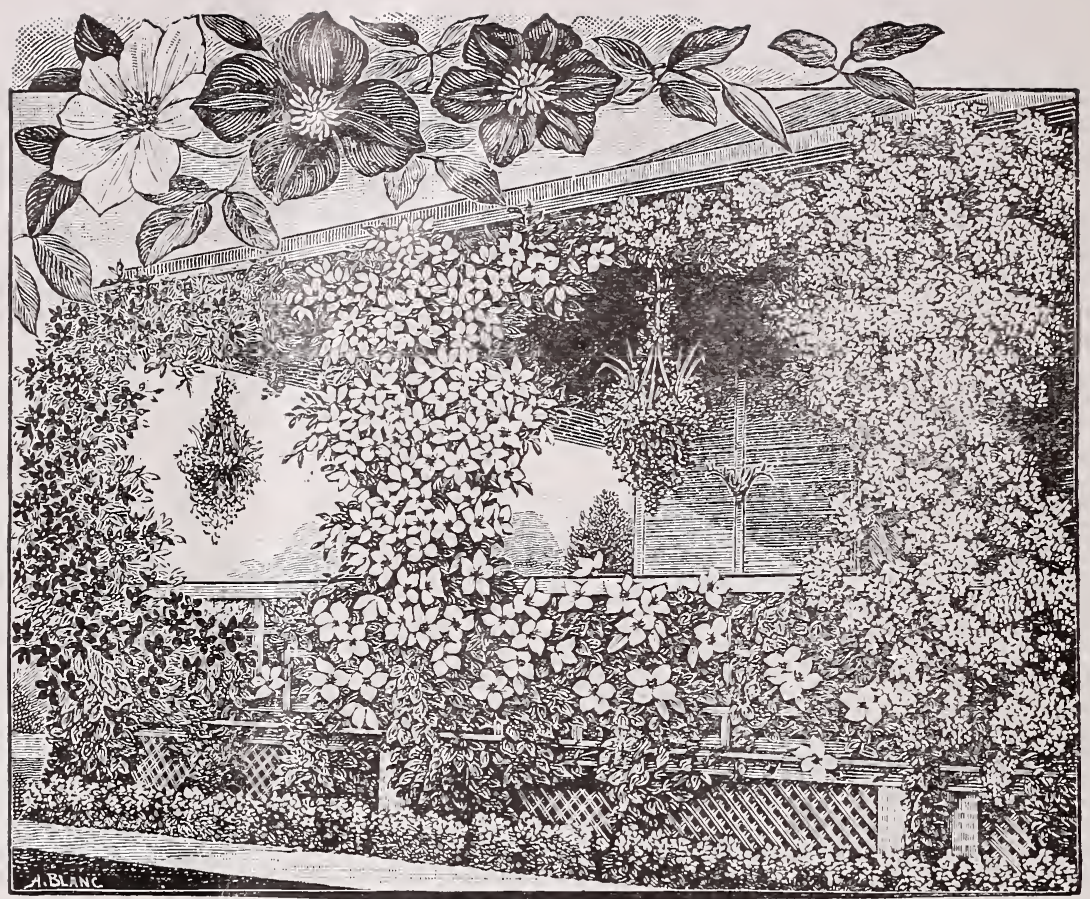

Clematis Jackmanni.

Clematis Henryi.

Clematis Paniculata.

\section{HARDY CLIMBING AND TRAILING VINES.}

AMPELOPSIS VEITCHII. Japan, or Bos ton lvy. This is justly one of the most popular of all the vines. It is neat in character; the leaves, which resemble the English Ivy in shape, overlap one another closely, forming a dense sheet of shining green, changing in the fall to the most vivid scarlet, purple and gold. Does not require any supporting as it is a selfclinger, and clings tightly to wood, brick or stone. Planted and trained to grow on and cover the stone foundation walls of a frame house, it adds a desirable attraction to the place. No buildings are considered too handsome to cover with this plant, and the most unsightly ones are made picturesque by its use. Should properly have protection the first winter, but after it becomes established is perfectly hardy and grows rapidly. The many handsome residences, public buildings and churches covered wholly or in part by this beautiful and appropriate vine attest to its great worth. We highly recommend Ampelopsis Veitchii.

When planted close to a foundation wall, a trying place for any stock, the ground shculd be frequently loosened, as in such position the surface of the ground is very apt to bake over quite hard. Origin, Japan.
CLEMATIS. As a climber for the veranda, a screen for fences, for training on walls or arbors, in masses on rockwork, or cultivation in pots, the Clematis has no rival among stronggrowing, blossoming plants. Blooming throughout the summer, nothing can excel the surpassing beauty of the many colors of the several varieties. The Clematis should be grown in rich, deep, sandy loam, and be well mulched with rotted manure in winter. The richest sheets of bloom and largest flowers are obtained where it has partial shade. All of the varieties we offer are entirely hardy, most of them are lavish bloomers, and the majority blossom the first season after transplanting.

When planted close to a foundation wall, a trying place for any stock, the ground should be frequently loosened, as in such position the surface of the ground is very apt to bake over quite hard.

CLEMATIS. Coccinea. An American variety and unlike any other Clematis. The vines attain the height of from 8 to 12 feet, beginning to flower in June and continuing until frost. The flowers are bell-shaped; a rich, deep coral scarlet, and last a long time when cut. Early summer bloomer. 
CLEMATIS. Flammula. (European Sweet). Though the flowers of this rariety are individually small, they are very abundant in the late summer and autumn months. Highly prized for their perfume, which resembles that of the Hawthorn, but is much swetior.
CLEMATIS. Paniculata. This valuable white Clematis, a native of Japan, has, after a thorough trial of sereral years, proved entirely hardy. The deep, clear green foliage is unusually broad and healthy, and remarkably free from all insect enemies. The flowers are pure white, often slightly tinged with cream, from three-quarters of an inch to an inch in diameter, starshaped, and with a most pleasing and penetrating fragrance. They are borne in heads on stiff stems 4 to 6 inches long, from the axils of the leaves. The fragrance is remarkable in its intensity, and is noticeable quite a distance. For any situation where a rapid-growing climber is needed, this will be foun ${ }^{3}$ a very valuable plant. The late season of blooming is a strong point, as most other climbers have passed their flowering stage by the middle of August, when this is just coming to perfection and continues blooming nearly a month.

\section{Ampelopsis Veitchii.}

CLEMATIS. Henryi. Of robust habit and a very fine bloomer. Flowers large, of ' beautiful creamy white, consisting generally of from 6 to 8 spreading sepals. Is a remarkably free and continuous bloomer, beginning with the earliest and holding on with the latest. One of the finest white varieties. June to October.

CLEMATIS. Jackmanni. This variety bears a profusion of large sized, intense violetpurple flowers, 6 inches across, richly veined and shaded with reddish purple. Is a rapid grower; an early and abundant bloomer; per. fectly hardy, $\boldsymbol{C}_{\text {and }}$ adapted to all kinds of culture; is equally fine, either as a climbing or trailing plant, and is well adapted for covering up unsightly objects. Planted out in a border or flower bed, it will produce the finest effect and give a continuous bloom through a long season, year after year.

CLEMATIS. Madame Edouard Andre. New Red Clematis. An entirely distinct and most novel variety, and the nearest approach to a bright red ever sent out. The plant is a strong, vigorous grower, being a hybrid of the popular Clematis Jackmanni, which it resembles in freedom of bloom, strong, vigorous growth, shape and size of flower, but is a distinct, carmine-red color of a most pleasing shade, entirely different from other varieties.

CLEMATIS. Mrs. George Jackmann. An English variety; color white; flowers single, large, some being 6 inches in diameter; strong grower; hardy,
CLEMATIS. Ramona. A new American seedling originated in Newark, N. Y. A very strong, rampant grower; very hardy, and a perpetual bloomer. The color of the flower is a very deep sky-biue, very distinct and attractive; flowers very large, many running as large as 18 inches in circumference. Peter Henderson says: "It has the largest and most attractive flowers of any Clematis I have ever seen."

CLEMATIS. White Perpetual. Where a white-flowering variety is wanted, and the customer prefers to have us select the variety best adapted to his section, the order can be given under this name.

HONEYSUCKLE. Hall's Japan (Lonicera Halliana). This vine has the advantage that "it will grow" under almost any conditions. The flowers are yellow, changing to a pure white, and are fragrant and abundant from June to September. Desirable for a porch. It should be trained to wire netting or some other support, for if allowed to lie on the ground every branch will take root, and it becomes difficult to eradicate except by constant pulling and hoeing up of all suckers not desired. For a "quick grower" plant Hall's Japan Honeysuckle. With a slight protection of leaves, straw or pine boughs, the leaves remain perfectly green most all winter. This is a valuable shrub for covering dry or steep embankments, which are difficult to cover with grass.

HONEYSUCKLE. Monthly Fragrant ( $L$. Belgica). Flowers red and pale yellow; sweet scented; blooms through the summer. 
HONEYSUCKLE. Scarlet Trumpet, Monthly (L. semper-virens). Flowers deep red, trumpet-shaped. Flowers all summer. A native climber, and appropriate for trellises and rock-work.

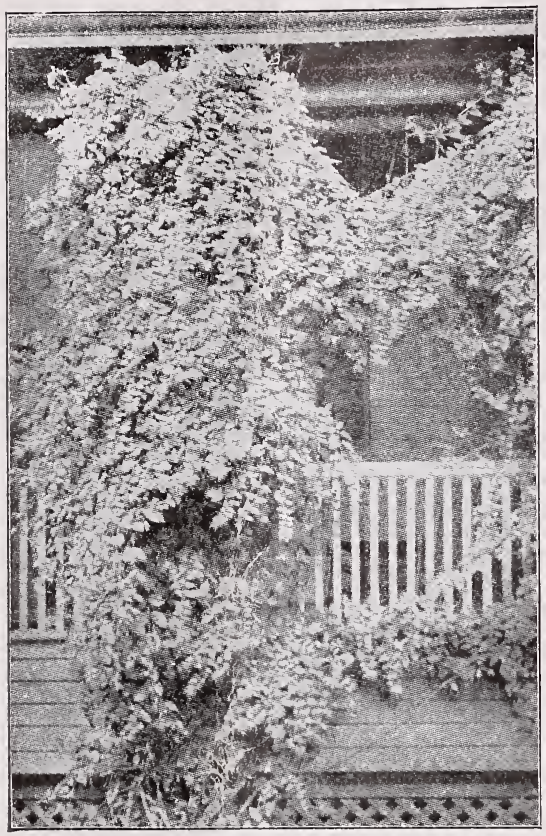

Honeysuckle, Hall's Japan.
HONEYSUCKLE. For Honeysuckle, Up. right Shrub, see under Ornamental Shrubs.

IVY. (Hedera). The evergreen sorts of Ivy often suffer in winter, if exposed to the sun, and should be planted on the north side of a building.

IVY. English or Irish. Old, well known sorts, used in covering the north side of buildings; leaves deep green.

IVY. Variegated. (Rombera variegata). Leaves small and pretty; variegated.

IVY. Boston, Japan. [See Ampelopsis Veitchii.]

WISTARIA. Chinese Purple (Sinensis pur purea). One of the most elegant climbing vines known, and a very rapid grower after it gets thoroughly established, sometimes making twenty feet of wood in a single season. Desir. able for porch. Bears long clusters of pale blue flowers in May and June, and also in September. Extremely hardy. Attains a larger size than any other climber.

WISTARIA. Chinese White (Sinensis alba). Differs from above only in the color of its flowers, which are smaller and pure white, forming a striking contrast. 


\section{Bulbs and Perennial Herbaceous Plants.}

DERENNIAL herbaceous plants and bulbs, which die down to or ne? the ground every fall, start up again from the roots in the spring.

ANEMONE, Windflower. Japonica (Japanese). From Japan. Grows 2 feet high. Free, vigorous habit of growth, and in autumn produces a continuous abundance of bright red flowers until cut down by frost.

ANEMONE, Windflower. Alba. (Honorine Jobert). Pure white flowers. Choice for cutting purposes.

CAN NAS, Beaute de Poitevine. (French). An ideal dwarf variety. Foliage brilliant, shining green. Flowers good size, growing in large trusses of splendid crimson-scarlet.

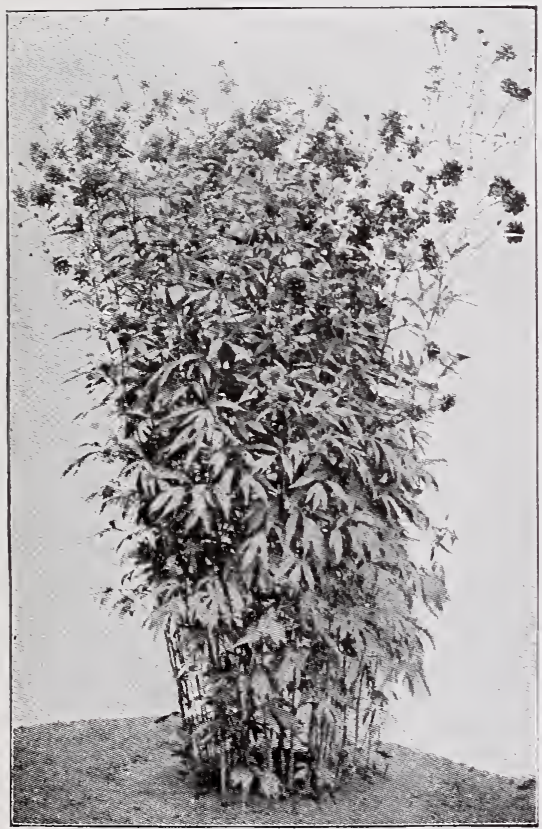

Rudbeckia, Golden Glow.

CANNAS, Rose Unique. (French). A charming variety of the everblooming French Cannas. Plants vigorous in growth, with lanceolate green leaves and beautiful, rose-colored flowers.

CANNAS, Italian Orchid-flowered. A distinct race of Cannas. The flowers are very large, often 6 to 8 inches across, and gorgeous in color ; are appropriately called Orchid-flowered. They have less substance and are thinner-petaled than the French rarieties, and are exceedingly free bloomers.
CANNAS, Austria, Immense, canary-yeilow flowers, with pale, brownish red spots. Giant in growth; foliage large and heavy. Young plants set out ir June form dense clumps of 20 to 25 stems 6 feet high, each surmounted with a spike of gorgeous golden flowers; lasts till frost.

CANNAS. Italia. These flowers, on massive stems about 16 inches long, are gorgeous in color, being a rich, golden yellow, with patches of brilliant red spots on the upper petals. The leaves are a rich, deep green, bordered white.

GLADIOLUS, The Gladiolus is one of the very handsomest of all the outdoor flowering bulbous plants. The plants give wonderful returns for but little outlay in time and care, and are very satisfactory for cut-flowers for the house, as all the small undeveloped buds will develop to the tip of the spike in water. Ther present the greatest variety of shades and coloring, from pure white with the slightest touch of pink through all the shades of yellow and pink to the deepest scarlet. They require nothing more than ordinary garden soil to do their best. The bulibs must be dug up in the fall, and may be planted from the time the ground is in shape to be worked in the spring, till July, and will begin to blossom in about six weeks.

GLADIOLUS, Lemoine Hybrids. Rather early, very gracefnl and beautiful; - inclined to the more delicate shadings, with beautiful soft contrasts.

GLADIOLUS, Crawford's Mixtures. Contain all kinds and all shades, from pure white to the deepest scarlet.

HOLLYHOCKS. These handsome, showy plants are at present great favorites. They are old inhabitants of our gardens, but are now so improved in doubleness an enlarged in size, as to be revelations of gorgeous beauty to those who have not seen these improved sorts. As a back ground there is nothing better, or for groups on the lawn or among shrubbery, they are invaluable. Flowers large and double, as handsome in form as a camellia, and of beautiful shades of color.

IRIS, German. Under this head are included the varieties of several species of Iris, but all are distinguished by their broad leaves, and resemble each other in the shape of their flowers, and for this reason are known under one nead. All of easiest culture in ordinary garden soils, preferring a rich loam. We sell them in assorted colors. 
IRIS, Japan. The plants we quote are recent importations from Japan, and are extra choice and rare. This is the latest and largest flowering of all the Iris family. Some specimens in the nursery measured over 9 inches across the petals. They are entirely hardy, and require no attention after being planted in good soil. They show the most charming combinations of colors; sone are pure white, others crimson, rose, lavender, lilac, blue, and others are mottled.

LILIES, Auratum (The Golden-rayed Lily of Japan). Pure white, with crimson spots, while through the center of each petal runs a clear golden band, the flowers nearly a foot across. Blossoms from June to October.

LILIES, Speciosum rubrum. Rose color, spotted with crimson.

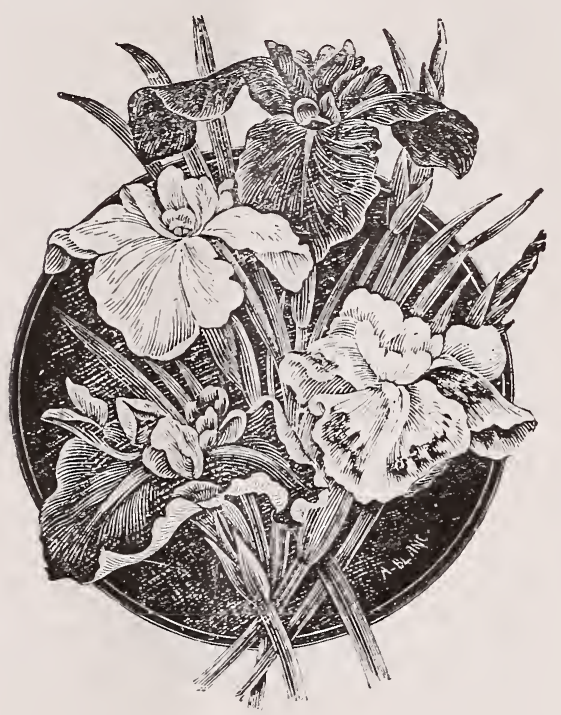

Japan Iris.
PAEONIES, Herbaceous. It is surprising that these elegant flowering plants are no more generally cultivated. Mist people seem to have

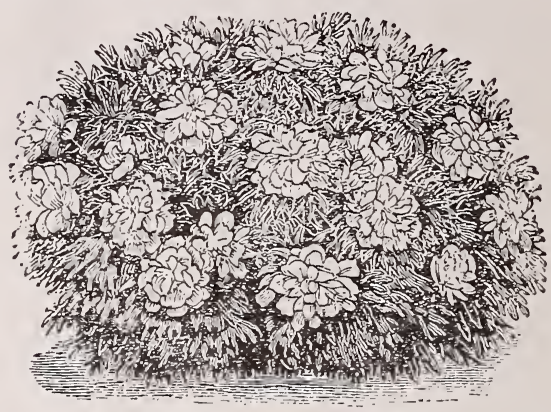

Pronia.

lost sight of the many beautiful varieties introduced within the last few years. They are absolutely hardy everywhere, have no insect enemies, and always live and gro'/ when prop. erly planted, increasing in beauty from year to year. They bloom in June and July, and may be planted singly or in groups. The foliage is rich and glossy, and of a beautiful deep green color, thus making the plants very ornamental when out of blossom. The plants attain a height of about 2 feet. We offer the following colors : Pink, Red, Scarlet, Crimson, White. These varieties are distinguished by the color of the flower. Order by color.

RUDBECKIA, Golden Giow. Cone Flower. We call attention to this notable novelty, and offer it as the finest hardy herbaceous border plant introduced for many years. It is of easy growth, and is giving complete satisfaction. A plant this season on our grounds, the second year from planting, had 1,380 flowers and buds on it, some of the flowers being $3 \frac{1}{2}$ inches in diameter. It made a great show, and but few plants can vie with it in attractiveness. There is no floral novelty before the public to be com. pared to it for effectiveness and worth. We recommend it. 


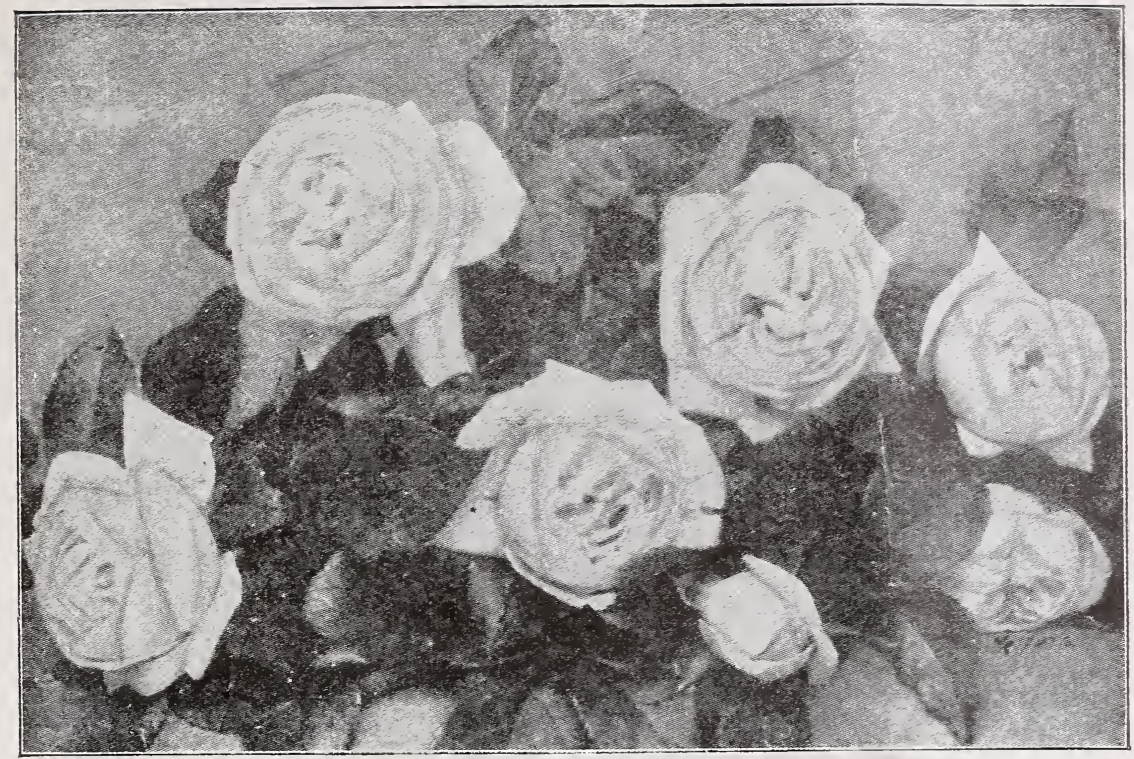

\section{MARGARET DICKSON. See Page 51. ROSES.}

T HE beauty of the Rose appeals to more people than any other flower. It succeeds best in a deep, rich soil, rather moist, and of somewhat clayey nature. There are more failures in growing the Rose from not making the soil rich enough than from any other cause. Perhaps the best line of treatment is to dig 18 or 20 inches deep, working in fine, rotten cow manure and leaf-mould to the full depth, and every fall banking rich stable manure up against each plant for protection. In the spring this should be spread over the bed and spaded in.

Winter Protection.-Most Roses will be much benefitted by tying the bush up with coarse rye straw. Pine boughs or leaves, packed in about the plants, are a great protection.

Our Hardy Roses, (the "H. P.," the "C.," and the "M.,") are strong plants, grown out of doors, well rooted, and every way desirable. They have usually bloomed in the nursery row before being sent out, and are in every respect much better and stronger plants than the ones that are advertised as being so cheap, and are sent out by mail, those being small tender shoots, started in a greenhouse, and, after a few weeks, sent out before they have established growth and constitution enough to stand the shock of transplanting. While for plants of this older age, grown and cultivated outdoors in the nursery rows, we have to charge our price, they are more than worth the difference, and will give much better results and satisfaction.

H. P. - In our list the term $(H . P$. ) denotes the hardy and popular classes mainly, called. Hybrid Perpetuals. They usually bloom profusely during June, and occasionally during the summer and autum. In pruning, the work may be done in the fall or in March, the latter time being generally preferred. The bushes should be so pruned as to obtain a limited number of as strong canes as possible, as, the stronger the canes, the larger will be the flowers. Weak shoots should be entirely removed or severely cut back. The two hardy yellow Roses, Harrison's and Persian, are quite similar to the $H$. $P$. class, in their strong hardy growth. All suitable for the garden or lawn.

C.-The Climbing Roses are hardy, and should be planted outdoors. They bloom profusely during June, and some kinds during the summer. Valuable for trellises, porches, etc.

M.-The Mosses are very hardy and fragrant. On account of the beautiful buds for bouquets and cut-flowers, a favorite class with all. Mainly June bloomers, altbough some kinds bloom during the summer. The buds have mossy covering on the outer leaves. Require close pruning. Suitable for garden and lawn.

T.-The tender list, marked ( $T$.) includes a variety of classes, which require protection during the winter. In most sections plenty of leaves, with evergreen boughs on top, are sufficient. Appropriate for beds in the lawn and for pot-culture in the house. They are profuse bloomers. 
Budded Roses should be pianted sufficiently deep so that the junction of the bud with the stock is from 2 to 3 inches below the surface of the earth.

We cannot too forcibly direct attention to the above rule.

For the convenience of the customer in making selections, we print the common everyday classification of Red Ru, se, Pink Rose, White Rose, etc., directly after the name of the Rose. The more complete coiv - description is also given.

Alfred Colomb. H. P. Dark Red. Flower very large, of fine, giobular form; a brilliant carmine-crimson. Raised from the Jacaueminot. Extremely fragrant flower, and in every way a superb Ro:e. Fine for general cultivation. Foliage large and handsome. A compact, handsome-shoped, very attractive Rose.
Baroness Rothschild. $H$. P. Pink. One of the most beautiful of Roses. The flowers, immense in size, are produced at the ends of strong stems, and closely surrounded with beautiful green leaves, thus setting off the exquisite pink flowers in the most effective manner. A late bloomer. A very choice variety.

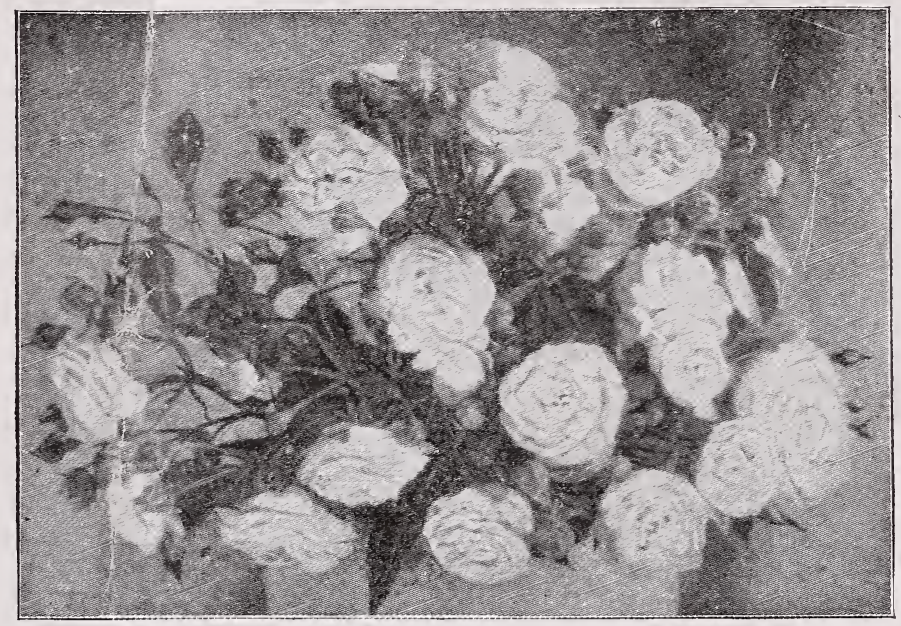

Caroline Marniesse.

American Beauty. H. P. Red. Flowers large, globular, very double, and of a full and very perfect form. Color a deep crimson; of delightful fiagrance. Plant a vigorous grower and constant bloomer.

Anne de Diesbach. H. P. Red. Flowers large and showy, and particularly fine in bud. Color a beautiful shade of carmine. Very fragrant. A fine gaidden sort; a vigorous grower, and one of the hardiest.

Baltimore Belle. C. White. Flowers very double, compact, and borne in large clusters; pale blush when first open, becoming nearly white. Flowers produced late in the summer, when other summer Roses are gone. Hardy. When it is desired to cover walls, unsightly buildings, etc., this and the Crimson Rambler, Gem, and Queen of the Prairie, are very efficient. Plant a vigorous grower.

Baron de Bonstetten. H. $P$. Dark red. Blackish crimson, with vivid red shadings. Large, full, and very fragrant.
Blanche Moreau. M. Pure White. Flowers full, large and of perfect form. The buds and flowers produced in clusters, and freely furnished with deep green moss. Hardy. Flowers in the autumn, at a time when other Moss Roses are not to be had, and therefore very desireable. Plant a vigorous grower.

Caprice. H. P. Pink, striped with white and red. Flower large; a decided novelty. Of the many striped hardy Roses, this is easily the best, the marks being very distinct. Easily grown, and a free bloomer.

Caroline de Sansal. $H$. $P$. Pale Pink. Flower flesh color, turning to blush. Large size, full and flat, sometimes irregular in form; generally best in the autumn. Plant one of the hardiest.

Caroline Marniesse. $H$. $P$. White. A hardy Noisette, that is always in bloom. As a bedding Rose, this variety has no superior. It is literally a continuous bloomer, the plant being constantly covered with flowers the en- 
tire summer. Order Caroline Marniesse, if you want a desirable hardy white Rose. The flowers are of medium size, full and double, borne in very pretty clusters. Color pure white, slightly tinged with pink, and with the delicate fragrance of the dainty Tea Rose. The bush is low-growing, 18 to 24 inches high, and especially adapted for a border or for cemetery planting. It is entirely hardy.

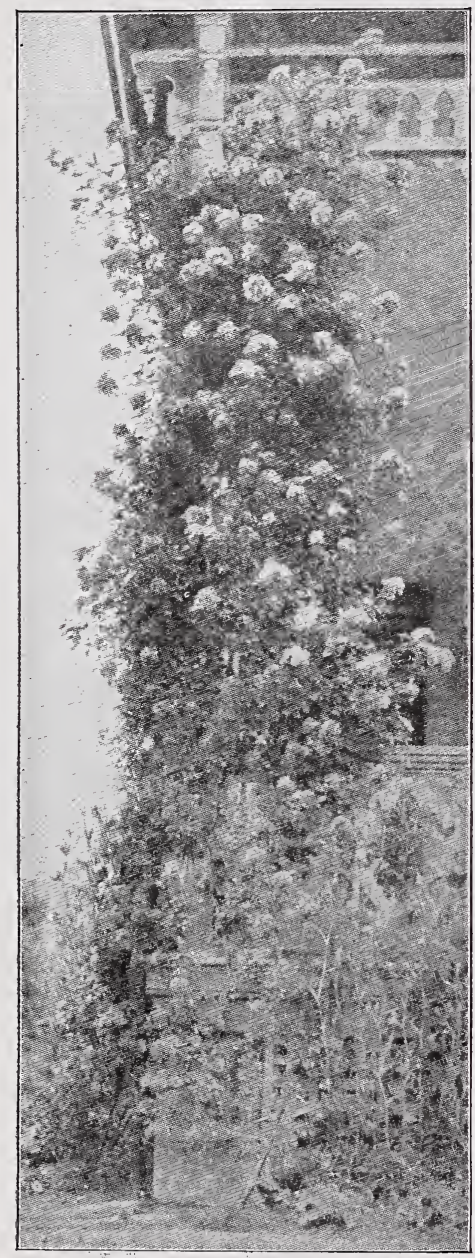

\section{Crimson Rambler.}

Climbing Jules Margottin. C. Red. Among the best of all the moderate-growing elimbing sorts. Color carmine. Is fine in open flower or bud. Hardy. May be grown as a pillar Rose, or by pruning kept in bush form. A vigorous grower, blooming at intervals from June to November. Does not make growth enough to cover large buildings, but is desirable for covering a trellis or pillar.
Climbing Victor Verdier. $C$. Rea. Flower is a brilliant carmine, edged with purple. Hardy. Very large, full and fragrant. Blooms at intervals from June to November. Does not make growth enough to cover large buildings, but is desirc ble for covering a trellis or pillar.

Clio. $H . P$. Light Pink. This is one of the finest Roses. It is of the most delicate texture and coloring imaginable. The plant is a very vigorous grower, entirely hardy, and the flowers are very freely produced throughout the summer. Flowers large, of fine, globular form; flesh color, shaded in the center with rosy pink. Plant of vigorous growth, entirely hardy ; handsome foliage.

Coquette des Alpes. H. P. White. Flowers medium size; white, slightly shaded with pink; in shape, semi-cupped. Generally flowers in small clusters, and blooms freely throughout the entire season. A choice variety. This is of the Hybrid Noisette class.

Crested Moss. M. Pink. The buds are graceful, surrounded with a mossy fringe and crest; are a deep pink, fragrant and very attractive. Blooms in June and July. Hardy. For cut-flowers and boquets the blooms are very desirable and handsome. The plant is free from mildew.

Crimson Globe. $M$. Red. Plant very strong-growing and free-blooming. Hardy. Buds rather pointed and well mossed, and of a fine, clear, rich crimson. The open flowers have the beautiful rounded form of Hybrid Perpetual Roses, instead of the rather flat, less attractive shape of other Moss Roses.

Crimson Rambler. C. Red. Hardy. This wonderful Japan Rose is one of the most important and valuable hardy Roses introduced in many years. It is a running or climbing Rose, vigorous in growth and entirely hardy. It begins to flower about the middle of June, and remains in bloom a number of weeks. Produces a marvelous abundance of clusters made up of from 20 to 50 brilliant crimson flowers, each flower perfect in shape, from 1 to $1 \frac{1}{2}$ inches across. The clusters cover the entire length of the bush, making a magnificent appearance against the background of beautiful glossy foliage. We cannot say too much in praise of this beautiful Rose, and our customers will make no mistake in purchasing it. An elegant Rose for verandas, walls, pillars and fences. From the Philadelphia Rocord, June 10, 1899:

A Crimson Rambler Rose bush that contains 9,600 blossoms is the remarkable feature of the garden at the home of John Parry, No. 3517 North Thirty-fifth street, Falls of Schuylkill. Last year the bush was considered a wonder, but then the blooms numbered only 6,500 . Every day hundreds of people visit Mr. Parry's place and admire the bush, which its owner displays with great pride. Each cluster of the rose is a bouquet in itself. The bush is 10 feet in height, and spreads over quite an amount of space. Mr. Parry is confident that he has the champion Rose bush in this section 
Earl of Dufferin. H.P. Dark red. One of the finest Roses of recent years. Flower is a rich brilliant, dark velvety crimson, shaded with dark maroon. For a beautiful dark red Rose, plant the Earl of Dufferin. A large, full and perfectly formed Rose, and delightfully fragrant. A valuable addition to any collection.

Fisher Holmes. H. P. Red. An extra large and beautiful Rose. Rich scarlet, shaded with deep, velvety crimson. Resembles General Jacqueminot, but is fuller, darker, and a more constant bloomer.

Gracillis. M. Deep pink buds, surrounded with delicate fringe like moss. One of the most beautiful of all the Moss Roses, having graceful buds. Hardy. We highly recommend Gracillis. It blooms in June and July.

Gem of the Prairie C. Red. Flowers very large and flat, and produced in clusters. Color red, occasionally blotched with white. One of the few climbing Roses that is fragrant. Flowering season June and July. Hardy. This and the crimson Rambler, Queen of the Prairie and Baltimore Belle, are very efficient when the covering of some large space with a screen of Roses is desired, as they are all very strong, rapid growers.

General Washing ton. H. P. Red. Flowers bright, rich crimson and perfectly double. Blossoms freely in June.

General Jacqueminot. $H . P$. Red. Without a rival for fragrance and richness of color. Beautiful in the bud state, and also when open. One of the best known Hybrid Perpetuals, and truly deserving of the popularity it has gained. Not as full a Rose as some, but is very attractive and effective. Blooms freely all summer. A bunch of "Jack" Roses is certainly most beautiful.

Harrison's Yellow. Yellow. Hardy. Flowers of medium size, semi-double, of a golden yellow. Blooms freely in June. The plant is a strong-growing bush. If pruned closely will not bloom, as the flowers are produced from the terminal shoots of the wood, so only shorten a few inches the shoots left for flowering.
John Hopper. H. P. Red. Brilliant red, with crimson center, and large and fine in form. Very fragrant.

La France. Hybrid Tea. Light Pink. The delicate fragrance of the La France is appreciated by everyone who grows or wears a Rose. One of the most perfect types of a cutflower Rose. A silvery Rose, shaded with pink, with a satiny sheen over all the petals, unsurpassed in delicate coloring. Flowers large, and produced at intervals from June to Nov. A moderate grower.

La Reine. H.P. Pink. Flowers large,

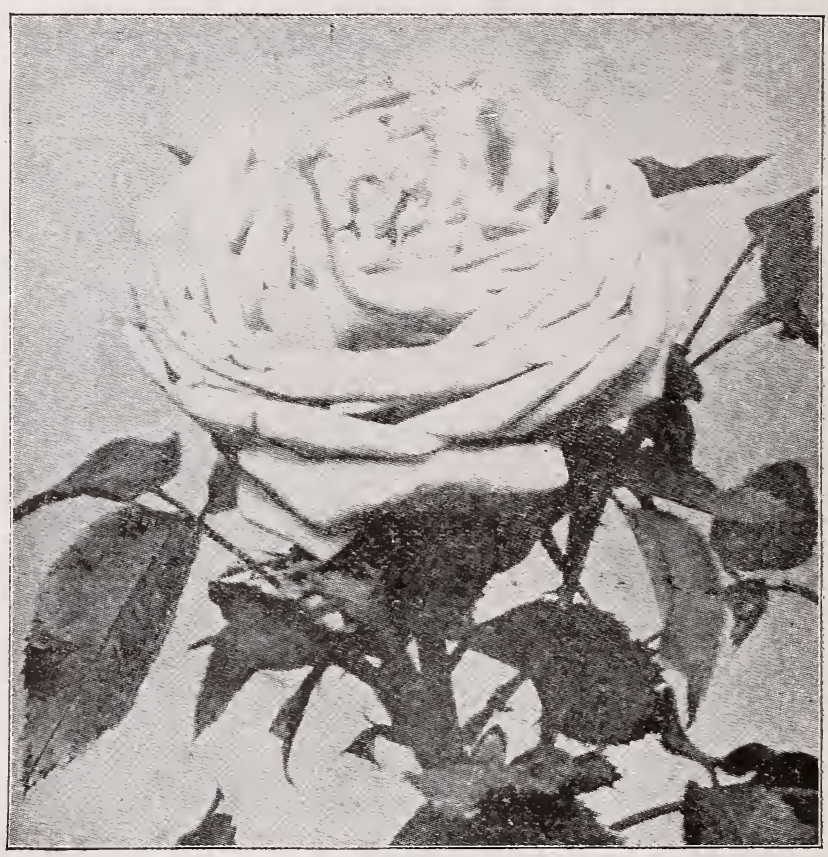

Magna Charta.

moderately full, color pink. The plant is very free-flowering, and one of the most hardy.

Mada me Gabriel Luizet. $H$. P. Pink. Perfection in color, being a clear, silvery pink. Flowers extra large, with broad, shell-like petals ; a cup-shaped, elegantly formed, very double and full Rose. $A$ bunch of these pink Roses is superb. Hardy, and easily grown, and a profuse bloomer in June.

Madam Plantier. H. P. White. Flower full and above medium size; pure white, and produced abundantly early in the summer flowering season.

Madame G. Bruant. Rugosa. White. One of the first of a new race of hybrids. In the bud state the flowers are long and pointed, when open, semi-double; pure white and fragrant, and produced freely in clusters at inter- 
vals throughout the summer; exceptionally hardy and vigorous; forms a handsome bush.

c Magna Charta. H. $P$. Pink. Flowers extra large, globular, and very double ; fragrant. Color pink, suffused with carmine. Blooms profusely; season June and July. $A$ valuable Rose, worthy of being extensively planted.

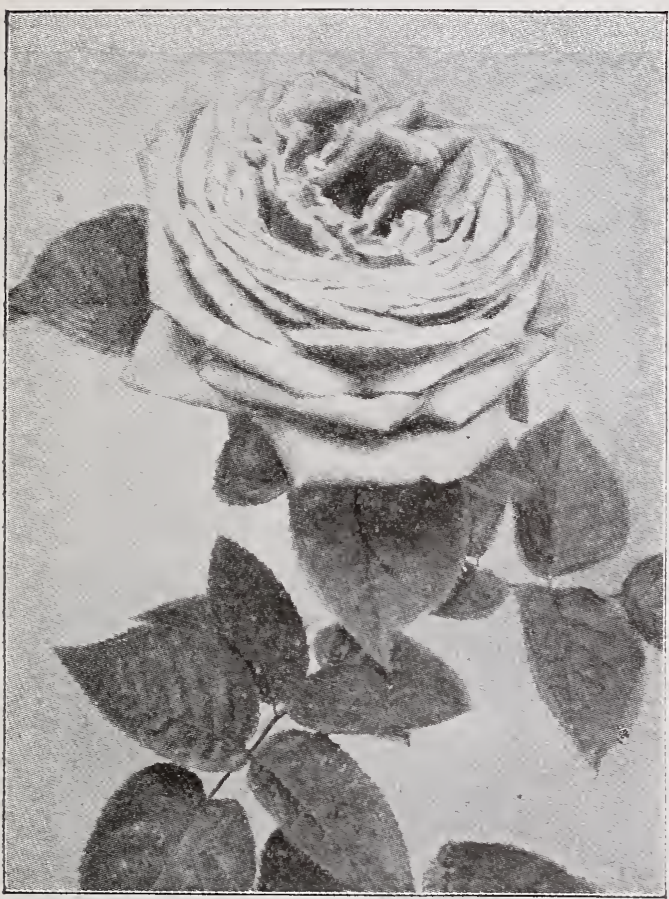

Marsha!l P. Wilder.

Mrs. De Graw. T. Pink. Color is a rich glossy pink, very fragrant. Flowers large, cupshape. One of the best of all the Bourbons. Remarkably prolific and a continuous bloomer.

Marchioness of Londonderry. $H$. $P$. White. Flowers of great size, measuring seven inches across, perfectly formed, and carried on stout stems. Color ivory white; petals of great substance, shell-shaped and reflexed; free flowering; highly perfumed; growth vigorous, and foliage very handsome. One of the finest Roses. Awarded the gold medal of the National Rose Society of England.

Marchioness of Lorne. $H . P$. Red. Large, full and cup-shaped, with buds long and very handsome. Remarkable for constant blooming. Color a rich red, shaded a vivid carmine. Plant a vigorous grower.

Marechal Niel. T. Deep yellow. An ideal climbing Tea Rose. The flower is peerless in its deep yellow color and perfect in its very full, globular form and immense size, blooming at intervals from June to July. Is highly scented. Plant is of delicate constitu- tion, and requires careful treatment to secure satisfactory results. A natural climber, and should not be pruned severely. Valuable for training to climb up a sheltered pillar.

Margaret Dickson. H.P. White. This is the finest white Hybrid Perpetual yet produced, and is a long step forward in Rose culture. Some idea of its beauty and worth can be formed from the fact that it was awarded the gold medal of the National Rose Society of England and six First-class Certificates. The flowers are of the purest white, with pale flesh centers; petals very large, shell shaped; a Rose magnificent in form and very large, rivaling in size, and in its late fall blooming, the Paul Neyron. Is fragrant. Foliage very large, dark green. A vigorous grower, and for hardiness is called "iron clad."

Marshall P. Wilder. $H$. $P$. Red. A Rose of unusual excellence. Raised from the seed of General Jacqueminot. It is of vigorous growth, with healthy foliage, and a free bloomer. Marshall P. Wilder is one of the very best. Flowers large, semi-globular, full, well formed. Color a cherry-carmine; very attractive. Very fragrant. Flowers profusely during a long flowering season.

Maurice Bernardin. $H$. $P$ Red. A good, free-blooming sort. Flowers large, generally in clusters. Perhaps the most prolific of all crimson Roses in the spring.

Mrs. John Laing. H.P. Satiny pink. For outdoor planting, this is one of the best Roses introduced for many years. Entirely hardy, and blooms almost constantly throughout the season. Flowers of immense size, full and double, exceedingly sweet and fragrant, borne in great profusion on long, stiff stems The buds are long and pointed, and extremely pretty. Color of flower is a clear, bright, shiny pink, with the most exquisite shadings. Plant a vigorous grower. One of the most satisfactory varieties.

Paul Neyron. H.P. Deep pink. By far the largest flower of any Rose under cultivation, often 5 inches in diameter. A free bloomer, and very desirable as a garden Rose. Strong in growth, often attaining 6 to 7 feet a season.

Perpetual Red Moss. $M$. Hardy.

Perpetual White Moss. M. Hardy.

Having many calls for a good red Moss Rose, or a good white Moss Rose, we book orders under these titles, and supply the finest varieties of the color selected by the customer. Let your order read "Perpetual Red Moss," or "Perpetual White Moss," to designate the color of flower wanted.

Persian Yellow. Yellow. Hardy. Flowers nearly full, small but handsome, and a very 
early bloomer. Season of flower June and July. "The hardy yellow Rose of our mother's garden." If pruned too closely, they will not bloom, as the flowers are produced from the terminal shoots of the old wood, so only shortten a few inches the shoois left for flowering.

Prince Camille de Rohan. $H$. $P$. Darkest red. A magnificent Rose, and very desirable for its large, handsome, fragrant flowers, which are produced so abundantly. Color is a deep, rich, velvety crimson, which runs into a deep maroon, shaded black; in fact, it appears black at a short distance.

Princess Adelaide. $M$. Pink. Flower of medium size and good form. Pale rose color. Good in bud or flower. Hardy. Foliage very blotched or variegated. Should not be pruned severely. Blooms in June and July.

Queen of the Prairie. C. Red. Of rapid growth, and with luxuriant foliage. Flowers bright, rosy red, sometimes striped with white, produced in large clusters. Blooms in June and July. Pretty on porches or trained to pillars. Hardy. When it is desired to cover walls, unsightly buildings, etc., this and the Crimson Rambler, Baltimore Belle, and Gem of the Prairie are very efficient.

Rugosa Roses. Hardy. The plant is highly ornamental on account of its good habit and beautiful glossy foliage. We have the Rugosa alba, with single, pure white flowers of five petals; highly scented. Also the Rugosa rubra, with single, beautiful bright, rosy crimson flowers, succeeded by large berries of a rich, rosy red color, which are a great addition to the ornamental character of the plant. (See also Mme. George Bruant's description.) All of Japanese origin.

Salet. $M$. Bright red. Flower full, pretty in the bud; an abundant bloomer. Flowers in the autumn, and valuable, as they come at a time of the year when "summer" Moss Roses are not to be had. Hardy. Good, fair grower.

Souvenir de la Malmaison. T. Pinkish white. Color a delicate flesh, shaded with fawn. Flower flat in form; very large for a Tea. A moderate grower. Plant not quite hardy, but a slight protection is sufficient in the winter. A continual bloomer at intervals from June to November, with rich, luxuriant foliage, and is most beautiful in the autumn. Flowers for the most part are produced in clusters, well shaped and somewhat fragrant. Suitable for planting singly or for low beds on the lawn.

TREE ROSE. These are grafted on tall stems of the Dog Rose, forming a half-weeping head 4 to 6 feet from the ground. They can be furnished in dark and light colors only, but the particular varieties grafted in the head cannot be named. Orders must be by color only, thus: "Tree Rose, Light," or "Tree Rose, Dark." One color only on each tree.

Ulrich Brunner. $H . P$. Red. Raised from Paul Neyron. Brilliant cherry red, a very effective color ; flowers of fine form and finish, carried well upon plant; petals of great substance ; plant vigorous, hardy; resists mildew.
Victor Verdier. H. P. Red. Bright rose, carmine center, a very fresh shade of color; not fragrant; free bloomer; wood nearly smooth. This variety, with its numerous progeny, is more tender than any of the other types in the class. A beautiful Rose.

White Rambler. $C$. White. This Rose is a valuable addition to the list of climbers. Hardy. The flowers are of the purest snowwhite, blooming in clusters, completely covering the plant as the Crimson Rambler does. Blooms about the middle of June, the flowers remaining on the plant four or five weeks.

WICHURAIANA, Trailing or Creeping Rose. A low, trailing species, its stems creeping on the earth almost as closely as the Ivy. The flowers are produced in the greatest profusion, in clusters on the end of every branch, after the June Roses are past, from the first week in July, throughout the month. They are pure white, $1 \frac{1}{2}$ to 2 inches across, with yellow stamens, and having the strong fragrance of the Banksia Rose. It is quite hardy, with the exception of the latest immature growth, which may be cut back to some extent. This variety has proved valuable for covering banks, rockeries, etc., and for cemeteries. A distinct, valuable variety from Japan.

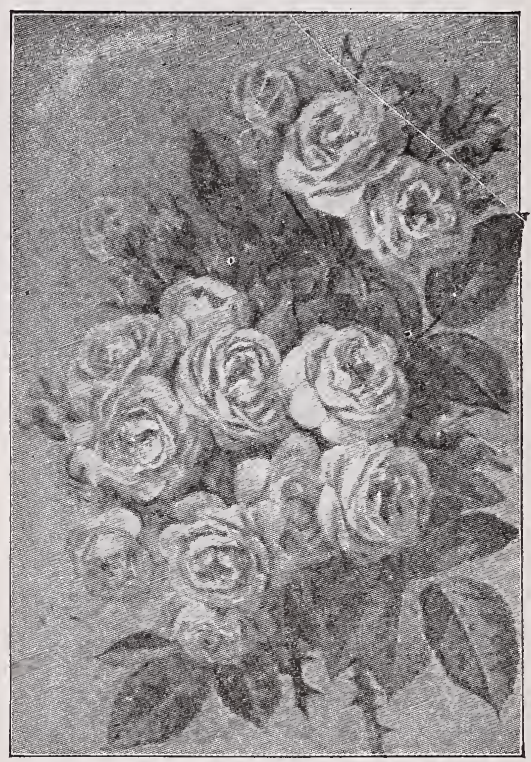

Yellow Rambler.

Yellow Rambler. C. Yellow. Markedly similar to the Crimson Rambler. Flower is 2 to $2 \frac{1}{2}$ inches in diameter, growing in clusters of from 20 to 50 . Yellow in the bud, but cream-white when fully open. Beautifully fragrant. Hardy. Plant vigorous and freeblooming, and the flowers remaining on the bush for weeks. A bush in full bloom is one of the most beautiful sights imaginable. 


\section{Frau Karl Druschki \\ or (Snow Queen.)}

\section{Now offered for the first time in this Country}

$\prod$ HIS exquisite new rose is the only absolutely pure white rose ever Mad. Caroline Testout and the grand old white rose, Marveille de Lyon. It possesses the free blooming qualities of the former and the robust growth of the latter. It is

\section{Perfectly Hardy Everywhere}

and a most vigorous grower, throwing up enormous shoots, which are covered with snow-white blossoms. Although we have so many socalled white roses, it is a fact that before the introduction of

\section{Frau Karl Druschki,}

we have not had a pure snow-white hardy rose. Heretofore the white roses have been tinged with pale pink or cream color. A grand rose sure to be in great demand.

\section{BLACK BEAUTY}

\section{The Darkest Rose in the World. Perfectly} Hardy. A Consistent Bloomer.

This grand new rose is beyond question the finest dark Hybrid Perpetual Rose yet introduced. Wherever exhibited it has received first honors.

In form and habit it greatly resembles Prince Camille de Rohan, excelling that popular favorite in color and fragrance. The color is a rich brilliant red, passing to velvety fiery-red, one of the very brightest colored roses we have. The flowers are very double and produced in greatest profusion. They are large, full and sweet; very showy and handsome, beautiful in the bud as well as when fully matured, and highly fragrant.

The plant is a healthy, vigorous grower, perfectly hardy, and blooms constantly, throwing up fresh buds and flowers the whole growing season. 


\title{
THE BABY RAMBLER ROSE
}

\author{
or CRIMSON RAMBLER in Bush Form
}

\section{Ever Blooming from June until Late Frosts}

\section{INDIVIDUAL FLOWERS HAVE BEEN}

$\mathrm{N}^{\circ}$ O introduction to the floral world ever made so great a success as the Crimson Rambler Rose. It has been planted by the millions in all parts of the country, and up to this time has never been equaled as a hardy, brilliant and strikingly handsome climber.

Its weak points, however, were the shortness of its blooming season, and its adaptability as a climber only. With this elegant rose as a type of perfection it was natural that every effort to improve it would be the desire and life work of the Horticulturists throughout the world. That which invariably takes generations to accomplish has been brought about in a comparatively short time, being the introduction of the Baby Rambler.

This beautiful acquisition originated at Orleans, France, and is a crossing of Crimson Rambler and Glorie des Polyanthus. Fortunately it preserves the flowering qualities of the latter, and retains the color and large panicles of the Crimson Rambler.

The foliage is of a fine polished dark green, and is never attacked by insects or fungus. It blooms in clusters and is very continuous. The time of blooming of the first umbel is not ended when the adjacent branches are ready to open with a considerable number of flowers, so that the period of blooming is not interrupted until after severe frosts. This rose will be very popular on account of the formation of the clusters, being covered with flowers the whole Summer, and will be especially valuable for culture in pots.

The Winter of 1903-1904 was the most severe experienced here in many years. The plants stood out in our nurseries here, during all that winter, without any protection whatever. Spring found these bushes alive to the tips of their branches. We have no hesitation in saying that the bushes of Dwarf Perpetual Crimson Rambler are perfectly hardy and vigorous. The plants grow 24 to 30 inches high. We can supply dormant field-grown plants.

\section{THE ROSE IS A PRIZE WINNER}

having taken the following prizes: At Paris, in May, the Grand Silver Miedal; in November, Certificate of Merit of First Class by the National Horticultural Society of France; at London, in April, Certificate of Merit of First Class by the Royal Horticultural Society of London; at London in June, Certificate of Merit of First Class by National Rose Society of England; at Orleans, France, in August, judged and rated by the Horticultural Society of Orleans and Loriet, Gold Medal-Highest Prize; at St. Louis, Mo., Expoposition, 1904, Gold Medal-Highest Prize. 
ONLY a few years ago little or nothing was known about fungus diseases, and almost nothing about the insects that trouble the fruit grower. But we know now the life history of all the common insects, as well as the fugus diseases, and know how to combat them at each stage of their life. It is only necessary to follow directions, and be prompt and thorough, to insure success. A man will spend weeks cultivating his corn field, that will barely yield a crop to cover the labor, and begrudge a week's time to his fruit, that will yield him returns running into hundreds of dollars in profit per acre. We give below some general directions for spraying and caring for fruit, that, if followed, will insure success.

INSECTS.-There are some insects that escape our attention entirely, unless we look closely. Among these are the gnats, mites, scale-lice and the ordinary plant-lice. These are all insects that live by sucking the sap of the plant for food, and have to be combatted with some mixture that dries on them, stopping up their breathing pores, which are arranged along their sides, or else by their caustic action eats away their tissues and destroys them. They have a great many natural enemies. Among them are the Ichneumon Flies-a fly looking much like a tiny wasp, and the Lady Bug. The insects that eat the leaves for food, such as the Potato Bug, the Apple Tree Tent-Caterpillar, etc., are killed by poisoning their food, and some form of arsenic has been found best for this purpose.

FUNGUS. - Fungus is a plant-a parasite plant-living by throwing its roots in the tissues of the plant on which it lives, and appropriating its sap. It grows very rapidly when once started, and, as it is beneath the skin of the leaf or bark during the greater part of its life, if once started it is hard to stop, so that to be successfully combatted work must be begun before any signs of the fungus appear. Usually fungus shows itself conspicously only when it has gone to seed. Its seeds are called spores, and are transmitted from plant to plant by the wind. To the naked eye they appear like grains of very fine dust.

FORMULAS. - NотE. - Wherever lime is called for in the following mixtures, it is to be weighed before slaking, then slaked and the creamy white wash, after straining to remove lumps, added to the solution.

Formula I, Paris Green. Paris Green, 3 ozs.; lime, 1 1b.; water, 1 barrel. Keep well stirred.

Formula 2, White Arsenic Solution. This is to take the place of Paris Green, and is very much cheaper, costing about 4 cents per barrel. Boil 2 pounds of white arsenic, with 8 pounds of sal soda (common washing soda) in 8 qts. water for 15 minutes, or till dissolved, leaving only a small muddy sediment at the bottom. Put this solution in a 2-gallon jug and label "Poison, stock material for spraying mixture."

Use one pint of this to a barrel of water. But this will burn the leaves and greatly injure the tree if lime is not added, so to each barrel of mixture add 2 pounds of lime.

Formula 3, Bordeaux Mixture. Copper sulphate, 4 pounds ; lime, 3 pounds ; water, one barrel. Dissolve the copper in a part of the water, slake the lime in another part, and mix, fillingthe barrel with water. Another way, and a better way where several barrels are to be made, is. as follows: Make several bags of burlap or old sacking. Weigh 4 pounds of copper sulphate. in eaci. Slake a bushel of lime in a barrel of water. Go to your druggist and get a cent's wort $\%$ of ferro-cyanide of potassium, and get an extra label to paste on your bottle. Put this ferro-cyanide in a 1-ounce bottle, and fill it with water. It will all dissolve, or nearly all. Paste. on your poison label, for it is very poisonous. To prepare the mixture : Fill a barrel nearly full of water, and hang a bag of copper in it, so that it does not rest on the bottom. If it rests on the bottom it will take a day or so to dissolve, while if you suspend it, it will dissolve in an hour. When copper is dissolved, stir up the barrel of lime and dip out enough adding it to the copper, till a drop of the ferro-cyanide solution does not turn brown when added to it. It is then neutral, and ready for use.

Bordeaux Mixture is for fungus diseases, and by adding Paris Green to it, or white arsenic solution, it can be made a remedy for both fungus and insects. Three ounces of Paris Green to the barrel is enough, or 1 pint of the stock solution of white arsenic. If the latter is used, 2 pounds more of lime must be added.

Formula 4, Kerosene Emulsion. Kerosene emulsion is made by adding 2 parts of kerosene to 1 part of a solution made by dissolving half a pound of hard soap in 1 gallon of boiling rainwater, and churning the mixture through a force pump with a rather small nozzle until the whole forms a creamy mass, that will thicken into a jelly-like substance on cooling. The soap solution should be hot when the kerosene is added, but of course must not be near a fire. The emulsion thus made is diluted before using with 9 to $2 C$ parts of cold water. 


\section{C.OMMON FUNGUS DISEASES.}

Apple and Pear Blight. Follow directions in Spraying Calendar, and in addition, cut off and burn all the affected parts as soon as noticed.

Apple Scab. Follow Spraying Calendar.

Grape Rot. Follow Spraying Calendar. Manilla paper bags, securely pinned over the bunches, early in the season, are a preventive of the rot, and also a protection against birds, wasps, and other insects.

Powderly Mildew on Grapes. Follow Spraying Calendar, and dust the vines with powdered sulphur two or three times during the season.

Black-knot of Plum and Cherry. Spray with Formula 3, and cut off all knots, cutting back into good wood, and buri.

INSECTS.-Apple.tree Borer. The round-headed apple-tree borer (Saperda Candida) is a larva hatched from the egg of a brownish beetle, with two longitudinal white stripes along its back, which deposits its eggs late in June or July near the surface of the ground, where the bark is tender. As soon as hatched, the grub gnaws its way into the inner bark or sapwood, and continues to girdle and perforate the trunk during three summers, coming out of the tree at the end of three years in the beetle form. There are a number of remedies for this pest. (1) Examine the tree, and cut the borers out with the point of a knife, or kill them by thrusting a flexible wire as far as possible into the holes. The place where the larva enters can usually be detected by the sawdust-like castings that are pushed out. (2) To prevent the parent beetle from laying eggs, apply to trunk cf tree, the last of April or early in May, and again about a month later, a solution made by mixing 1 quart of soft soap with 2 gallons of water heated to boiling, and then add a pint of crude carbolic acid. Apply with a scrub-brush or cloth.

Flat-headed Apple-tree Borer (Chrysobothris femorata). The adult is a beetle about half an inch long (belonging to the Snapping Beetle family), and is very dark green above, with bronze reflections, especially in the furrows of the wing covers. It aspears in June and July, and lays its eggs on the trunk and limbs of apple, peach, oak, and other trees. The larva first bores into the bark and sapwood, and later into the solid wood. The larva matures in one year. Rub the branches and trunk with soap during June and July, or place a piece of soap in the crotch of the tree, so that the rains will dissolve it and wash it down over the trunk.

Peach Borer (Sannina exitiosa). These grubs hatch from eggs deposited (usually during May, but also at different times until last of September) by a slender, dark blue 4 -winged moth. They become small white borers, penetrating and devouring the sapwood, emerging again the next spring in the winged form, and depositing eggs for another generation. The remedies are : (1) Cut out the borers, as recommended under Apple-tree Borers. (2) Earth up (about 1 foot high) around the trunks of the trees in early spring, and level down in October, and when leveling down, if any bugs have entered, trace and kill them. (3) If you don't earth up, apply the solution recommended for painting the trunks of apple trees for borers. It is now becoming the custom to paint the crown of the tree with gas tar. This should be done in the spring. killed.

All borers that infest nut-trees, shade-trees and grape-vines should be hunted out and

Apple-tree Tent-Caterpillar (Clisiocampa Americana). This is the larva of a dull, reddish brown or yellowish brown moth, with 2 whitish lines on the fore w!ngs. The eggs hatch in early spring, just before the leaves appear. The larvæ that first hatch feed on the unopen buds. The entire brood that hatch from one cluster of eggs keep together and build a tent, in which they live. The larvæ leave the tent daily in search of food, and spin a silken thread wherever they go. They are fully grown the latter part of May or early in June, and at that time may be found crawling about the ground in search of a suitable place to spin their cocoon. The larvæ may be distinguished from the Forest Tent-Caterpillar by having a white line down the back, while the Forest Tent-Caterpillar has a row of spots, one on each segment. The adult moths appear about the middle of June. The eggs are soon laid, each female laying all her eggs in a ring-like cluster about a twig, where they remain unhatched until the following spring. The easiest way to fight the pest is to destroy the webs, containing the larvæ, as soon as they appear in the spring. This should be done early in the morning or late in the afternoon, or on a cold day, when the larvæ are not scattered over the tree feeding. Use a pole with a forked end, twisting the nest on it, and stamping the worms to death. On small trees, strip off by hand, or apply Formula 1 or 2 at the same time as for Codlin Moth, as the same application destroys both. 
The Cankar Worm (Paleacrita vernata and Alsophila pometaria). The sluggish, wingless lemale moth rises out of the ground very early in the spring, and slowly ascends the trunk of the tree, lyying eggs in clusters on the bark, to which they are secured by a grayish varnish. These usually hatch about the time the young leaves begin to grow, when the little worms begin at once to feed on the foliage. The larva is a "measuring worm" or "loop worm" of a pale brownish color, marked with darker brown and yellow. Encircle the trunk of the tree with bands of canvass or heavy paper 4 or 5 inches wide, which have been thickly s meared with tar, thus trapping the female moth. Or use Formula 1 or 2, at the same time, and as recommended for Codlin Morh.

Grape Flea Beetle (Haltica chalybea). So called because their thighs are very large, and fitted for jumping. The beetle is about one-sixth of an inch in length, and of a dark, steel-blue color. It eats the buds in the early spring, and later gnaws holes in the leaves. In May and June the sluggish larvæ, brown in color, may also be found feeding on the upper surface of the leaves. Spray with formulas 1 and 2-early for the beetles, and later, in May and June, for the grubs.

The Grape Leaf.Hopper (Erythroneura vitis). Pass between the rows at night with a torch, shaking the vines to start the insects. They will fly to the light and be cestroyed.

Dlant Lice. Spray with kerosene emulsion (Formula 3).

Apple Worm or Codlin Moth (Carpocapsa pomonella). The parent moth of this insect de posits its eggs in spring in the blossum end of the young apple, beto re he latter has turned down on its stem. From this egg there hatches a small worm that eatstits way towards the core, fceding and increasing in size as the apple develops, causing the fruit to drop prematurely. Apple Formula 1 or 2, just after the blossoms have fallen, and before the young apple has turned down on the stem; and in case there is a washing rain afterward, repeat the application. Apply by maans of a force-pump and spray-nozzle, throwing the liquid above the tree, so that it will settle in a fine mist.

Curculio (Conotrachelus nenuphar) a great enemy of the plum, apricot and cherry. Jar the trees, and catch the insects upon sheets and burn or likewise destroy them. Another remedy is to spray the plum tree soon after blossoms fall with formula 1 or 2 , repeating the application once or twice at intervals of ten days.

Army Worm (Leucania unipuncta). This is the larva of a moth of dull brownish color, marked in the center of each fore-wing with a distinct white spot. The larva is $1 \frac{1}{2}$ inches long when full grown, and is striped with black, yellow and green. It is present every year, but attracts attention only when it appears in great numbers. In seasons of serious outbreak it usually appears in limited areas in meadows or pastures. After destroying the vegetation in the field where the eggs were laid, it marches like an army to another field. If discovered before it has left these places, it can be confined by surrounding the field with a ditch, or killed by formula 1 or 2 , or other fields may be protected by a ditch with vertical walls in the same way, and by digging a post-hole here and there in the bottom of the ditch the worms wil! fall to the bottom, and can be destroyed. See Spraying Calendar.

\section{SUITABLE DISTANCES FOR PLANTING.}

Apples, Standard...32 to $40 \mathrm{ft}$. apart each way Apricots. 16 to 18

Blackberries....2 ft. in row, $6 \mathrm{ft}$. between rows Cherries, Sweet.....18 to $20 \mathrm{ft}$. apart each way "Sour.......16 to 18 "

Currants. Gooscberities.

4 to 5 " " 4 " 5 " "

Nectarines. Pears, Standard....16 to $18 \mathrm{ft}$. apart each way " 20 " Plums................16 to 12 to "

Peaches.................16 to 18 "

Quinces................14 to 15 “

Raspberries........... 3 to 7 "

\section{NUMBER REQUIRED FOR AN ACRE.}

At 3 feet apart each way

At 4 "

At 5 "

At 6 "

At 8 "

At 10

At 12

At 14

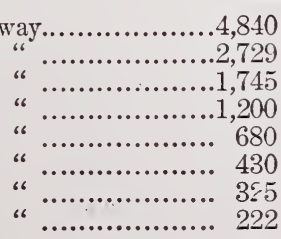

At 15 feet apart each way. 200

At 16 " " " "

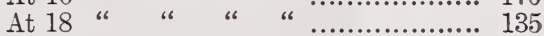

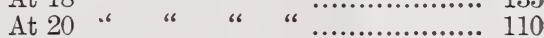

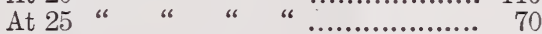

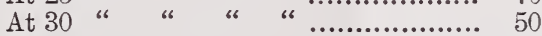

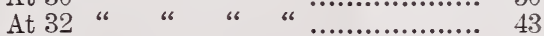

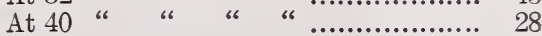

To estimate the number of plants required for an acre at any given distance, multiply the distance between the rows by the distance between the plants, which will give the number of square feet allotted to each plant, and divide the number of square feet in an acre $(43,560)$ by this number: The quotient will be the numher of plants required. 


\section{SPRAYING CALENDAR.}

EXPLANATION.-While the number of applications recommended will be found desirable in seasons when the fungi are particularly troublesome, a smaller number may often suffice. Whenever an asterisk $\left({ }^{*}\right)$ is used, it cautions against spraying with poisons while the plants are in blossom; a dagger $(\dagger)$ indicates that there is danger in making an application within three weeks of the time fruit is to be used.

\begin{tabular}{|c|c|}
\hline Plants. & Ist Application. \\
\hline $\begin{array}{l}\text { Apple: Scab, cod- } \\
\text { lin moth, bud } \\
\text { moth, caterpillar } \\
\text { canker uorm. }\end{array}$ & $\begin{array}{l}\text { After blcssoms have } \\
\text { formed, but before } \\
\text { they oper, Bordeaux. }\end{array}$ \\
\hline
\end{tabular}

Cherry : $R$ ot, As flower buds apaphis, curculio, pear, but before they slug, knot. open, Bordeaux; for aphis, use Kerosene Emulsior.

Currant: Mildew, As soon as worms worms. are found on lower and inner leaves, use Paris Green.

Gooseberry: Mildex, worms.

Grape: Fungus dise a ses, flea beetle.

Peach, Apricot: Before the blossoms Rot, mildew, leaf open, Bordeaux.

eurl, curculio,

Pear:Leaf-blight, Just before blossoms scab, psylla, cod- open, Bordeaux.* lin moth.

Plum: Fungus Within a week after diseases, knot, blossoms have fallen, rurculio, rot. repeat.*

Quince: Le af When blossom buds and fruit spots.

Raspberry, and Blackberry: $A n$ thracnose rust.

\begin{tabular}{|c|c|c|}
\hline & & $\begin{array}{l}\text { buds open, spray; with } \\
\text { Copper Sulphate so- } \\
\text { lution. }\end{array}$ \\
\hline $\begin{array}{l}\text { Rose: } \\
\text { aphis. }\end{array}$ & Worm, & $\begin{array}{l}\text { Kerosene Emulsion } \\
\text { for aphis. }\end{array}$ \\
\hline
\end{tabular}
diseased with anthrac nose and burn. Before

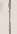

\begin{tabular}{|c|c|c|}
\hline 2d Application. & 3d Application & 4th Application. \\
\hline $\begin{array}{l}\text { Within a week after } \\
\text { blossoms fall, Bor- } \\
\text { deaux and Paris Green }\end{array}$ & $\begin{array}{l}10 \text { to } 14 \text { days la- } \\
\text { ter, Bordeaux and } \\
\text { Paris Green. }\end{array}$ & $\begin{array}{l}10 \text { to } 14 \text { days } \\
\text { ter, Bordeaux. }\end{array}$ \\
\hline
\end{tabular}
deaux and Paris Green Paris Green.

When fruit has set, Bordeaux and Paris Green.*

If they reappear, repeat, adding Bordeaux for mildew. $\dagger$

In 10 to 14 days, repeat with both.

As soon as the fruit has set, repeat.*

Within a week after fruit has set, use Bordeaux \& Paris Green.*

Within a week after the blossoms fall, Bordeaux \& Paris Green.

10 to 12 days later, repeat.

,

When fruit has set, 10 to 12 days Bordeaux and Paris later, repeat. Green.*

When new canes appear, Bordeaux and Paris Green.*

10 days later, use Bordeaux and Paris Green.

10 to 14 days la- 10 to 14 days, ter, if signs of rot Ammonical Carappear, repeat. bonate of Copper.

If worms still After the fruit is trouble,Pyrethrum picked, Bordeaux. or Helebore.*

10 to 14 days lato 14 days ash on English var.

10 to 14 days later, repeat.

7 to 12 days later, repeat.

8 to 12 days later, repeat.

10 to 20 days later, Bordeaux.

10 to 14 days later, repeat. $\dagger$

\section{Afterwards keep} lice and caterpillars off by turning a fine stream from hose on under side of leaves.

Do not spray with arsenite or copper compound within three weeks of the time the sprayed portions are to be eaten. While there would be no danger of fatal effects resulting, it is best not to run any risk. Bordeaux mixture and other lime compounds should not be used upon rough or full-grown fruits even as late as that time. Not only does the lime disfigure the fruit, but the amount of copper is large 

